\title{
School libraries in South Australia
}

\section{Census}

Katherine Dix

Rachel Felgate

Syeda Kashfee Ahmed

Toby Carslake

Shani Sniedze-Gregory
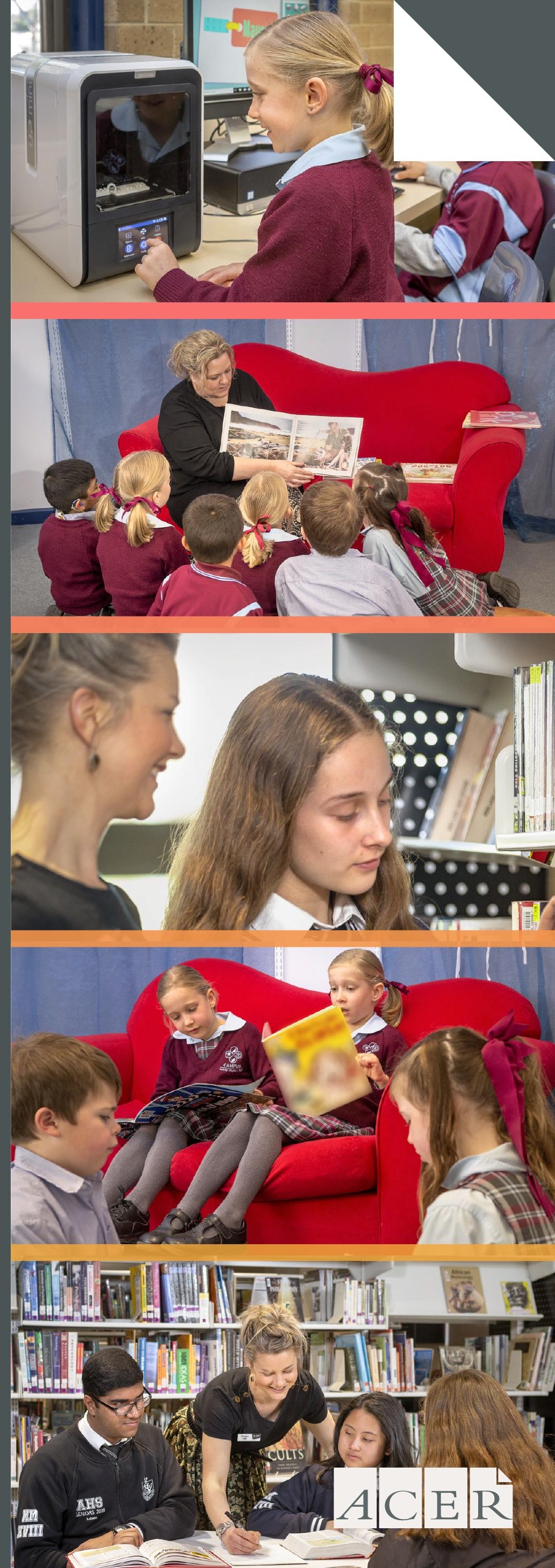
This publication was commissioned by the School

Library Association of South Australia.

www.slasa.asn.au

Australian Council for Educational Research Ltd

186B Pulteney Street

Adelaide SA 5000

Phone: (08) 82068600

ABN 19004398145

www.acer.org

ISBN 978-1-74286-583-6 (PDF)

The Australian Council for Educational Research Ltd (C) 2020

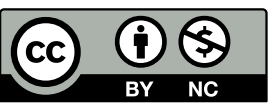

With the exception of logos, photographs, any material protected by a trademark and where otherwise noted, all material presented in this document is provided under a Creative Commons Attribution-NonCommercial 4.0 (CC-BY-NC 4.0) International licence: https:// creativecommons.org/licenses/by-nc/4.0.

The details of the relevant licence conditions are available on the Creative Commons website (accessible using the links provided) as is the full legal code for the CC BY-NC 4.0 licence: https://creativecommons.org/licenses/by-nc/4.0/legalcode.

Attribution

Dix, K., Felgate, R., \& Ahmed, S.K., Carslake, T., \& Sniedze-Gregory, S. (2020). School libraries in South Australia. 2019 Census. Adelaide, Australia: Australian Council for Educational Research. https://doi.org/10.37517/978-1-74286-583-6

ACER Research Repository https://research.acer.edu.au/tll_misc/33 


\section{CONTENTS}

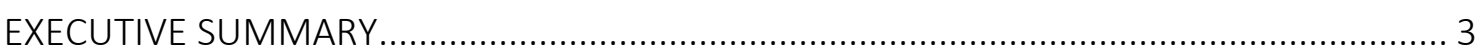

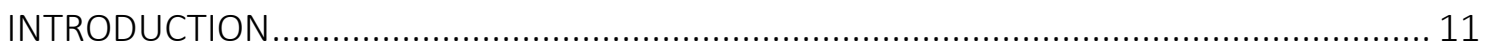

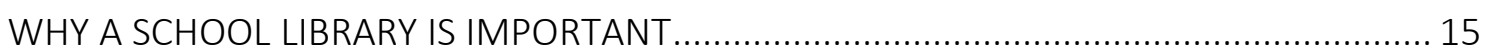

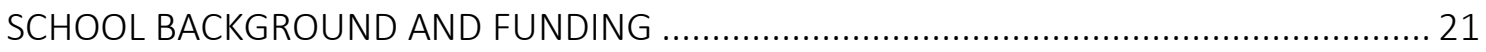

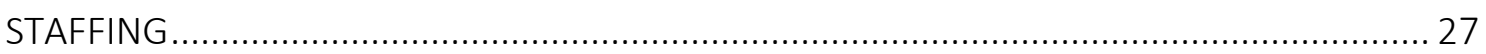

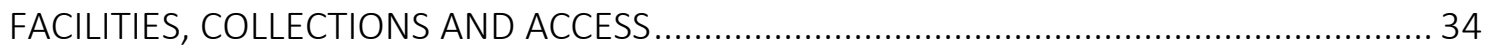

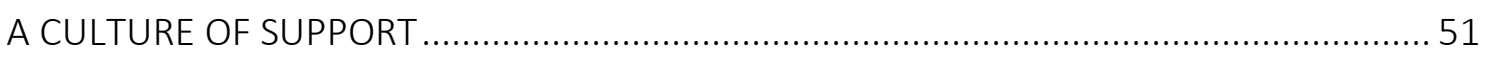

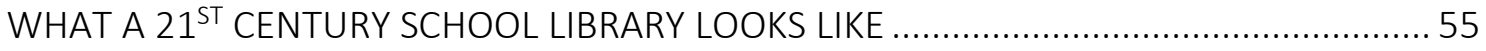

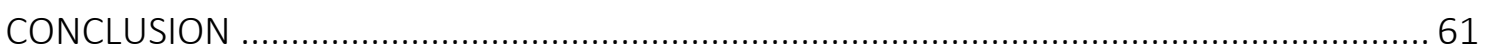

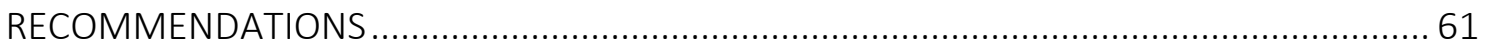

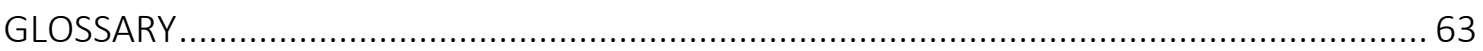

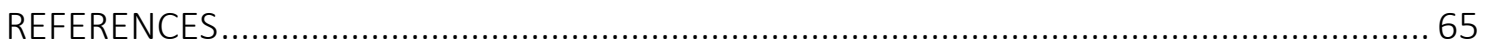

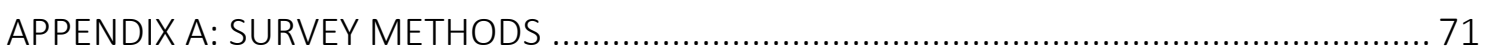

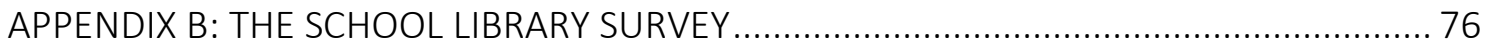

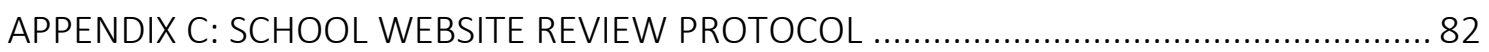

APPENDIX D: AEU SA BRANCH POLICY SCHOOL LIBRARY STAFFING .............................. 83 


\section{ABOUT ACER}

Working closely with the School Library Association of South Australia's (SLASA), this census was undertaken by a team from the Australian Council for Educational Research (ACER), headed by Dr Katherine Dix.

ACER is one of the world's leading educational research centres. As an international, independent, non-profit, non-government organisation, ACER generates its entire income through contracted research and development projects, and through developing and distributing products and services, with operating surplus directed back into research and development.

Contact details:

Dr Katherine Dix

The Australian Council for Educational Research

186B Pulteney Street, Adelaide SA 5000

P: +61882068633

E: katherine.dix@acer.org

W: www.acer.org

\section{ACKNOWLEDGEMENT}

This project was commissioned by the School Library Association of South Australia (SLASA). The Australian Council for Educational Research wishes to thank SLASA for their ongoing support throughout the study. In particular, we would like to acknowledge Hajnalka Molloy, SLASA President, for her steady guidance in this flagship project. We would also like to thank Pru Mitchell, Manager of the Cunningham Library, for her expert advice. 


\section{EXECUTIVE SUMMARY}

A Parliamentary Inquiry in 2011 into School libraries and teacher librarians in 21st century Australia, identified gaps in information regarding school libraries.

There is a fundamental need to collate some hard data to ascertain how many teacher librarians there are in Australia's primary and secondary schools; to identify where the gaps are; and to start to extrapolate the links between library programs, literacy (especially digital literacy, which is as important as regular literacy and numeracy skills), and student achievement (House of Representatives, 2011, p. 118).

In response, the School Library Association of South Australia (SLASA) commissioned the Australian Council for Educational Research (ACER) to undertake a census of school libraries and their staffing across all sectors (Government, Catholic and Independent) in South Australia. Driven by concern for student learning and equity of access to resources, the study aimed to gauge the nature of library provision and non-provision in schools, including the factors that support a school library and its staffing, as well as identifying how information services are managed when there is no library provision. This report presents the results of that survey census.

A literature review informed the development of a survey that aimed to overcome the issue of non-response bias and to address the absence of accurate information about the current nature of school library and information services in Australia. South Australia has pioneered this work, limiting the scope of this report to schools in South Australia. It serves as a model for education departments and policy-makers across all Australian education jurisdictions and federally, towards gaining an accurate and complete picture of school libraries and their staffing across Australia.

The lack of accurate information and hard data in Australia stems from previous school library surveys being directed to the teacher librarian, on the assumption that every school has one. Schools without a teacher librarian or a library are much less likely to participate, biasing results. To overcome non-response bias, this study used four innovative strategies.

1. The survey method used a census approach, involving every school in South Australia.

2. It was directed at school leadership (because every school does have one) and was designed to be answered by any member of the school leadership team.

3. It was called a School Library and Information Census to be inclusive of schools without a traditional school library, and to emphasise the involvement of all schools.

4. A review was conducted of the public-facing websites of all 728 schools in South Australia (a research first) to provide additional independent evidence of a library or information service in each school.

The census specifically aimed to collect data on areas related to staffing, support, facilities, and funding, guided by two overarching research questions:

1. What is the profile of school library staffing in South Australia?

2. What are the factors that influence school libraries and their staffing?

The survey was administered by ACER in Term 3, 2019 to the leadership of 728 schools in South Australia. All but 50 schools responded to the survey online, and these remaining schools were 
followed up with a phone call to achieve census. Almost $90 \%$ of respondents were library staff or the school principal. The 2019 snapshot that follows has yielded, for the first time, reliable and representative hard data about school library and information services in South Australia, with a view to informing future policy and funding decisions.

\section{Which schools currently have a staffed school library?}

- $94 \%$ of schools have someone to manage the library collection and to select resources. In just $23 \%$ of schools the person in this role is a qualified teacher librarian.

- Primary schools and combined K-12 schools with an on-site physical library, located in metropolitan or regional communities of medium SES status are more likely to have a staffed library.

- Schools with an annual recurrent library budget allocation of more than $\$ 2,500$ are more likely to have library staff.

- Small (<400 students) remote schools in disadvantaged communities are less likely to have library staff.

- Secondary schools with 'virtual' library access are less likely to have a staffed library.

- Special schools are less likely to have a staffed library.

\section{What is the profile of staff in the school library?}

- $51 \%$ of staff managing South Australian school libraries are not library-qualified, and $36 \%$ of staff are SSO/ESOs with neither teaching nor library qualifications.

- $23 \%$ of South Australian school libraries are managed by a qualified teacher librarian; $20 \%$ are managed by a library-qualified SSO/ESO.

Average profile of library staffing by size of school

$\square$ Qualified teacher librarian $\square$ Library-qualified SSO/ESO $\square$ Teacher $\square$ Unqualified SSO/ESO $\square$ Other

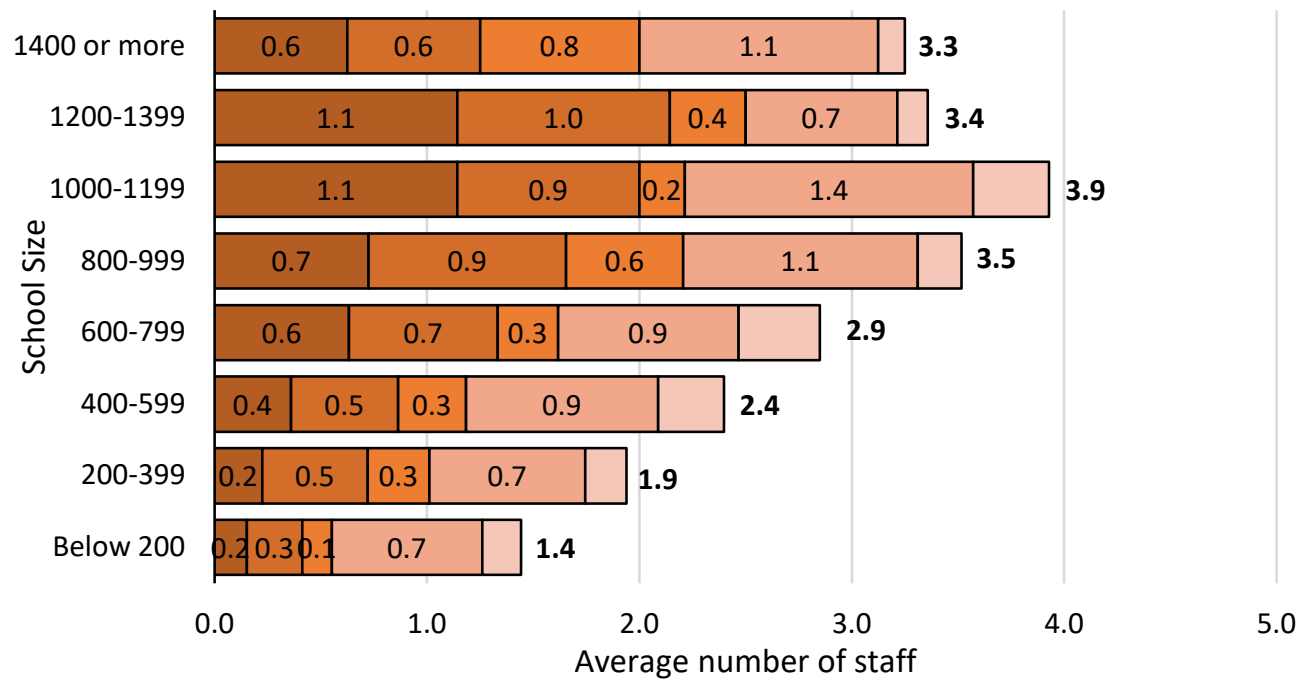




\section{What difference does a qualified teacher librarian make?}

- Having qualified library staff matters. Schools with a qualified teacher librarian in this role are more likely to have improved student literacy outcomes. Using NAPLAN 2018 data, students' reading, writing, spelling, grammar and punctuation outcomes at Years 3, 5, 7 and 9 were found to be significantly associated with the qualification-level of the person who manages the library.

- Students in schools with a qualified teacher librarian had up to two month's learning gain, compared to students in schools with no staff member managing the library, taking into account the effect of socio-economic status. The difference in Year 9 student literacy outcomes was particularly evident.

NAPLAN 2018 literacy achievement and role of the person managing the library

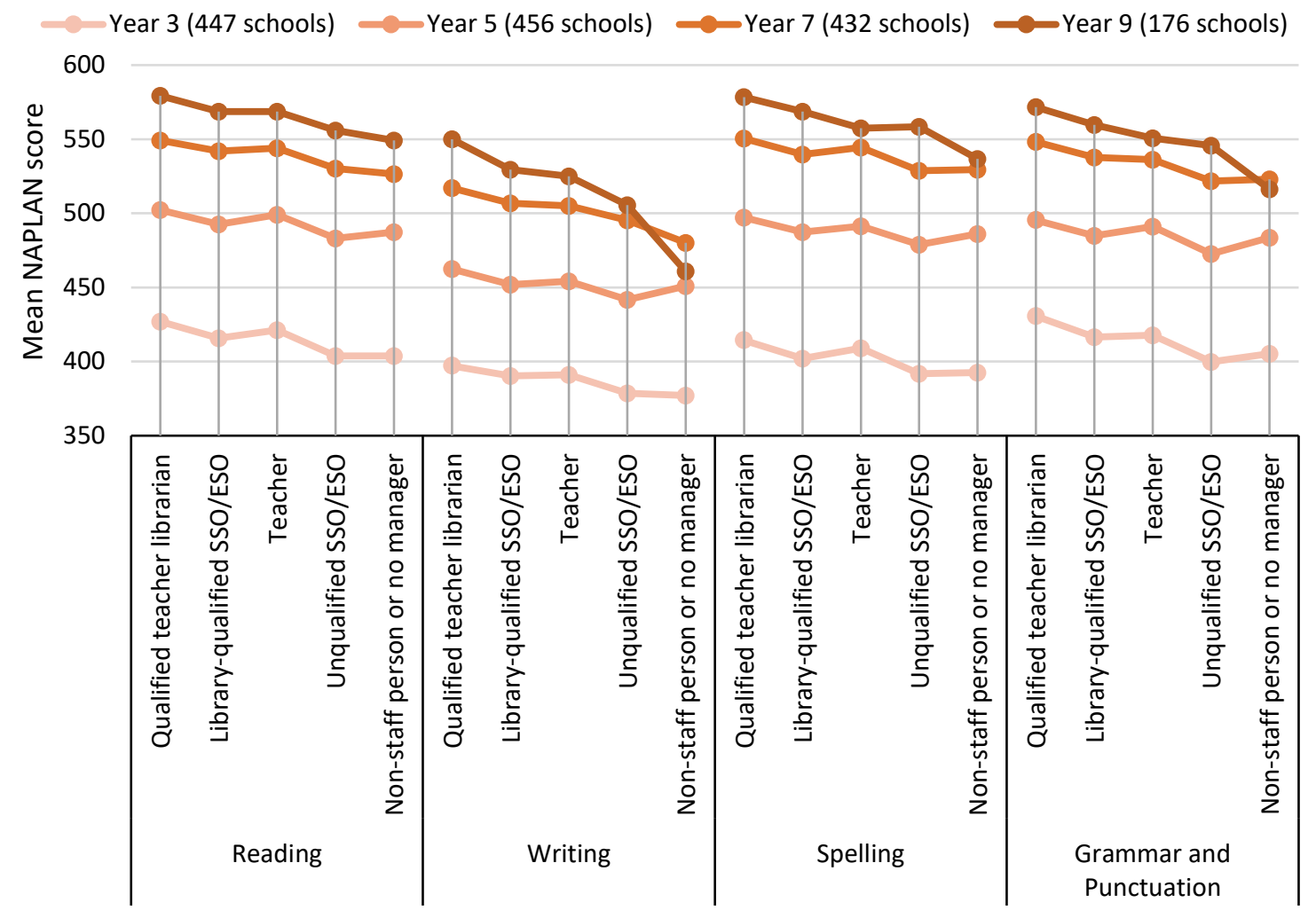

\section{How is library staff time used?}

- $55 \%$ of school libraries are managed on the equivalent of less than a half-time position. $19 \%$ of those managing the library are funded full-time (1.0 FTE). 26\% of managers are funded between 0.6 and 0.9 FTE.

- $34 \%$ of schools have a single library staff person (in part-time or full-time capacity). While staffing the library with qualified people is important, having a sufficient number of staff to run the library and information resources is equally as important.

- Library staff time is used in the following ways: 
- $70 \%$ of school library staff offer reader advisory services (helping staff and students to find appropriate resources)

- $62 \%$ offer one-on-one support according to student requests or small group support to meet student needs

- $52 \%$ offer flexibly timetabled lessons

- $39 \%$ offer collaborative planning with teachers and 35\% provide staff professional learning.

The library is a hub for students to enjoy the love of reading and students are pointed in directions of books of interest and research. It is a multi-use area that is enjoyed and used at all times by students/teachers (Regional primary school).

- School curriculum tasks that should, ideally, be managed by the teacher librarian are being done by other school staff. For example,

o research, study skills, and inquiry learning is managed by $18 \%$ of teacher librarians, with $55 \%$ of classroom teachers in other schools having to plan and manage this additional task.

o managing the school's literacy and reading program is the responsibility of $6 \%$ of teacher librarians, and an additional task for $39 \%$ of curriculum leaders or faculty heads.

o Copyright/Creative Commons and ethical use of information is more likely to be the responsibility of a classroom teacher (33\%) rather than a teacher librarian (23\%).

o developing referencing skills is more likely to be taught by a classroom teacher (52\%) rather than a teacher librarian (20\%).

This suggests there is clear opportunity to reduce the burden on classroom teachers by having qualified teacher librarians on staff.

- As part of their role,

o $91 \%$ of library staff ensure that the library is a safe place for students

o $88 \%$ run special events for the school community

- $84 \%$ select and purchase quality learning resources, and provide curriculum support to teachers

o $63 \%$ of libraries are a central learning hub, providing reading programs to nurture a love of reading

\section{What models of library are currently in place?}

Eight main modes of school library and information service provision to reading, research and curriculum resources exist across South Australian schools. Most schools refer to it as the library $(60 \%)$ or the resource centre (16\%).

- $94 \%$ of schools have a centralised library space on-site, ranging from the equivalent size of 2.2 classrooms in primary schools, to 2.8 classrooms in secondary schools, on average.

- $40 \%$ of schools with a physical library also have decentralised resource (for example, shared texts located in classrooms); $13 \%$ also have access to virtual online resources; $3 \%$ supplement their library with a mobile library service. 
- $4 \%$ of schools access library and information services through a jointly managed school community public library, mobile library, or other mode of off-site access.

- $3 \%$ of schools state they do not have a library or no evidence of a library could be found on their school website or publicly available documents (for example, context statement, or newsletter). These schools tend to be special schools or senior secondary schools.

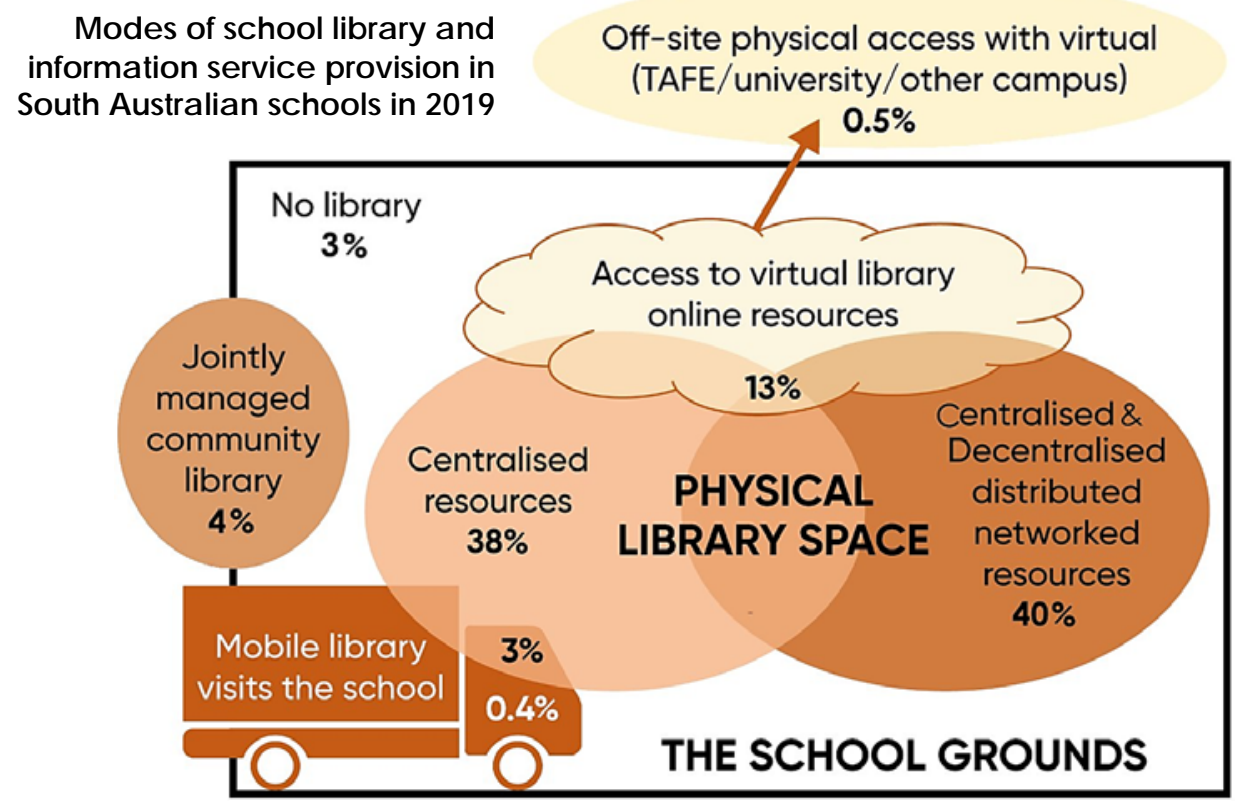

\section{How much dedicated space do school libraries have?}

- $79 \%$ of schools have dedicated space on-site for library activities and resources equivalent to two or more standard classrooms. $14 \%$ of schools have a classroom-sized library. $6 \%$ of schools had less than one classroom or no dedicated space.

- There is an obvious relationship with school size - bigger schools have more dedicated space - ranging, on average, from almost two classrooms' worth up to almost four classrooms' worth. For schools with less than 200 students that have a library, the size is equivalent to 1.7 classrooms. Schools with 400-600 students generally have dedicated library space equivalent to 2.6 classrooms. Large schools with 1200-1400 students generally dedicate the space of 3.8 classrooms to library and information services.

- High SES schools, secondary schools, and metropolitan schools tend to have more dedicated space than low SES schools, special schools and school located in non-metropolitan regions.

- $22 \%$ of schools report that their dedicated library space has been permanently encroached upon and repurposed, mainly due to STEM and digital learning, additional classroom space, additional staff office space, wellbeing counselling rooms, or downsizing. 


\section{How does technology fit in?}

- Over $90 \%$ of schools have shelving for shared resources, student quiet-reading spaces and borrowing services. A third of schools have a technology support centre and a quarter have a maker-space.

- $86 \%$ of schools have networked resources with laptops or tablets. $52 \%$ of schools have desktop computers in the library or computer hubs for information access.

- $37 \%$ of schools do not have any digital learning resource services, particularly if they are small and a primary or special school. Larger combined or secondary schools are most likely to have digital resources (for example, digital video; or subscription databases) and a library website.

- Schools report a diverse range of systems used to manage their resource collections.

o The Bookmark library management system is used in $82 \%$ of primary schools, $26 \%$ of combined schools, and $20 \%$ of secondary schools.

o Access-it is used in $3.5 \%$ of primary, $24 \%$ of combined and $30 \%$ of secondary schools.

o Oliver is implemented in $7 \%$ of South Australian in both primary, secondary and combined.

o Symphony is the system used in most School Community libraries.

\section{How are school libraries funded and what resources does this cover?}

- $98 \%$ of school libraries are funded via school budget allocation, and compete with all the other demands on the limited budget. $12 \%$ of schools also fundraise for their library.

- Library budgets vary as to what they cover in line with local school priorities. Associated expenses include buying books, database subscriptions, e-books and licence fees, along with refurbishment and improving technology access.

- The $18 \%$ of schools that have a budget allocation of between $\$ 2.5 \mathrm{~K}$ and $\$ 5 \mathrm{~K}$, tend to be smaller schools below 400 students.

- $16 \%$ of very small schools (less than 200 students) operate on less than $\$ 1 \mathrm{~K}$ annually.

- $19 \%$ of schools have a budget allocation of between $\$ 10 \mathrm{~K}$ and $\$ 20 \mathrm{~K}$, mostly larger schools above 600 students.

- For $62 \%$ of schools, the library budget has not changed from the previous year. However, $20 \%$ of schools report a budget decrease, some due to declining student enrolments associated with the shift of Year 7 from being the last year of primary school to being the first year of secondary school in South Australia.

\section{Is a culture of support reflected in a school's website?}

- Regarding support, $60 \%$ of survey respondents (some of whom are principals) report that their school library and information services are 'completely' supported and backed by school leadership. While $56 \%$ of participants completely agree that their library services are effectively managed, $36 \%$ are effectively funded and $31 \%$ are effectively staffed. 
- School libraries are significantly more likely to be supported by leadership and viewed as being well-managed and staffed if they are in larger schools with greater library budget allocation, managed by a qualified teacher librarian.

- Regarding being valued by the community, $50 \%$ of respondents believe that their school library provides resources equitably across the school community and 35\% of respondents believe their school libraries are completely well-resourced and current. $49 \%$ of respondents completely agree that their library and information services are valued by the school community and $41 \%$ believe that the library services contribute effectively to student learning.

- School libraries are significantly more likely to be valued by the school community if they are in a larger primary school, with moderate library budget allocation, managed by a qualified teacher librarian.

- There is moderate agreement between the survey results and website evidence gathered during the review of the 'public-facing' websites of all 728 schools in South Australia. Compared to schools with no evidence of a library (6\%), schools with a dedicated library webpage (16\%) are more likely to have libraries that are effectively managed, well-resourced and current, and valued by the school community. These schools are also more likely to provide resources equitably across the school community, and to contribute effectively to student learning. This finding supports Herring's (2007, p. 39) assertion that libraries that "are visible as part of the school website" do indeed reflect "the value which the school places on the school library".

Link between library presence on the school website and attitude towards the library

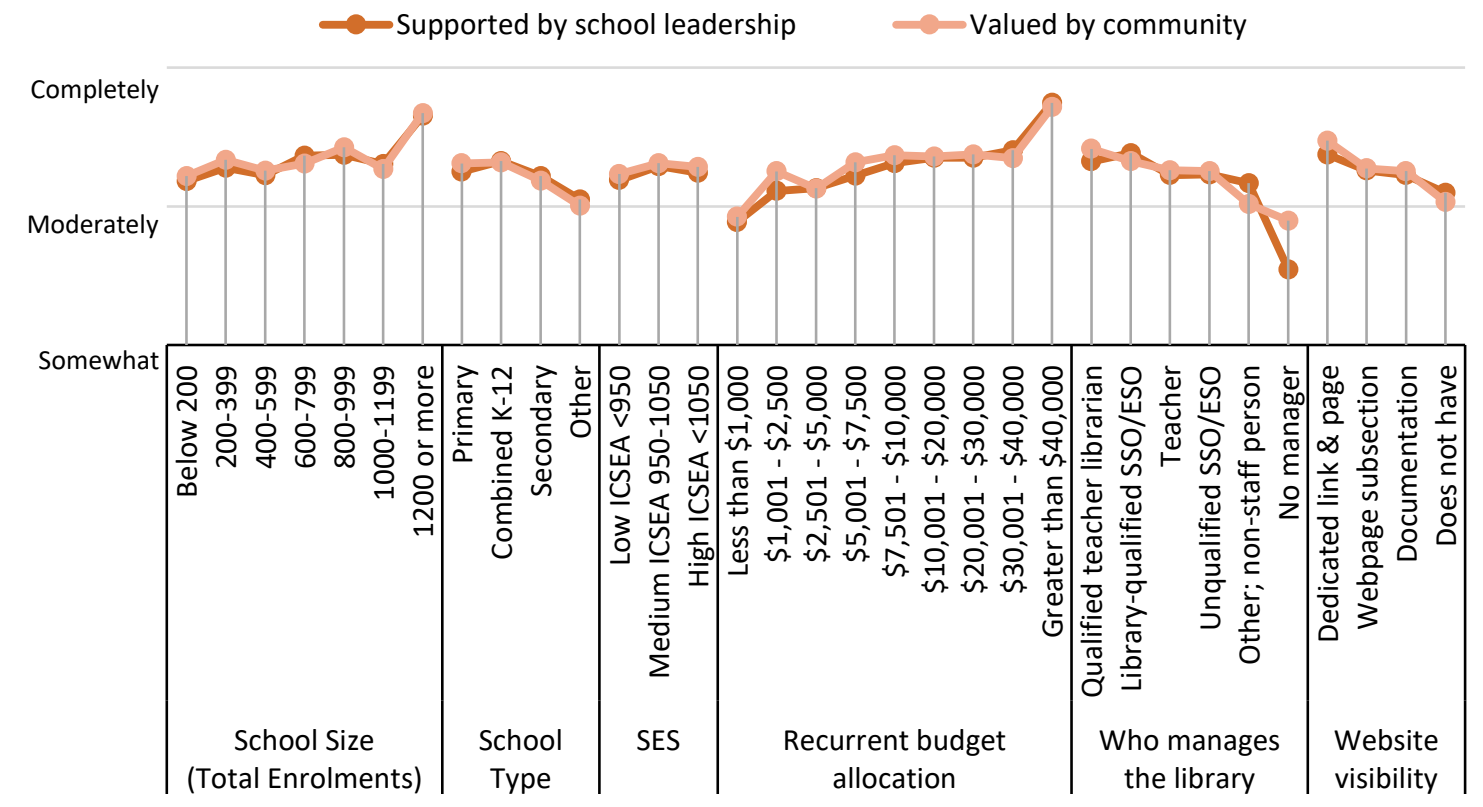




\section{Conclusion}

This 2019 census of school libraries in South Australia suggests a diverse cohort of dedicated but under-qualified staff, managing a complex array of library and information services, often in isolation, and at levels below AEU SA staffing recommendations. While school library services are reported as being valued and moderately effective, the library is often overlooked and not promoted to the wider community as a valued school asset.

The evidence suggests that school libraries without a qualified teacher librarian on staff $(77 \%$ of schools), are less valued and less effective as a basic library service, and may lead to lower student literacy outcomes. Schools with a teacher librarian show stronger NAPLAN literacy results.

While it appears that around 6\% of schools in South Australia do not have a physical on-site school library, all schools report having access to library-type reading, research and curriculum resources and information services, either virtually or through a community or mobile library.

There are challenges ahead, particularly in the short-term for primary schools with the decline in enrolments due to the Year 7 shift to secondary school. There is an undertone that things will get worse if budgets and floor space continue to diminish, if fewer school libraries are managed by qualified staff, if the culture of support declines, and if the rhetoric of library-less schools is normalised. Such trends run counter to the research evidence into what makes an effective $21^{\text {st }}$ century school.

Accordingly, it would be prudent to replicate this census in other states and territories, and over time, in order to inform policy decisions based on hard data, identifying trends in the provision of school libraries locally and Australia-wide. 


\section{INTRODUCTION}

This research project, funded by the School Library Association of South Australia (SLASA), aimed to conduct a literature review and survey of school libraries across all sectors (Government, Catholic and Independent) and their staffing in South Australia. Informed by the findings of an Australian government enquiry (House of Representatives, 2011), it specifically aimed to collect data on:

- Which schools currently have a staffed school library

- What models of library are currently in place (e.g. School library, School-community library)

- Staff in the library including their fraction of time and level of qualifications

- How this time is used, e.g. non-instructional release time for teachers, collaborative work with teachers, individual or small group support for students

- Amount of dedicated space for the school library, and how this is used

- Funding to the school library and nature of resources this covers

The overarching research questions were:

1. What is the profile of school library staff in South Australia?

2. What are the factors that influence school libraries and their staffing?

\section{Background}

The Australian Capital Territory (ACT) Education Directorate has called school libraries "the heart of 21st century learning" (ACT Education Directorate, 2019). Yet, very little is known about Australian school libraries - their nature, how they function, what kind of management support they receive or the type of programmes they run (Killoran, 2018). Other countries have attempted for some time to collate results from impact studies and research on school libraries and provide recommendations for moving forward. For example, in the United States, the report School Libraries Work! (Scholastic, 2016) brings together the research on effectiveness of school libraries across different states. In the UK, a report by the National Literacy Trust (Clark \& Teravainen, 2017) illustrates a contemporary picture of school libraries in that country. In Australia, several attempts have been made to collect information about the status of school libraries. School libraries in the ACT have been surveyed regularly (Godfree \& Nielson, 2018). Softlink surveys Australian and New Zealand schools annually, and occasionally data is collected at the state level through studies that capture mostly qualitative feedback from the teacher librarian. However, there are many gaps in the data that result in non-response bias, bringing into question the generalisability of results. Systematic, rigorous research that mitigates previous methodological limitations is yet to be undertaken in Australia. 


\section{Previous research into Australian school libraries}

The Australian Council for Educational Research has a long history of supporting the study of school library provision. The Munn-Pitt report of 1935 had a section dealing with school libraries. In 1945, one of Australia's first teacher librarians, Frank Kirby prepared a report on libraries in Victorian secondary schools for the Australian Institute of Librarians (Victorian Branch). In the foreword to that report ACER Director, Dr Cunningham, stated his vision that "the library should become the laboratory for all school studies" (p. 4). In 1961, Cunningham produced a history of this period of Australian libraries.

The publication of the 1966 report by Fenwick titled, School and Children's Libraries in Australia: a report to the Children's Libraries Section of the Library Association of Australia, is seen as the starting point for gaining government support for school libraries in Australia (Bundy, 2002; Ryan, 2018). As a consequence of this report the Library Association of Australia (LAA) at the time argued for the establishment of an appropriate federal body and advisory committee, creation of demonstration libraries in schools, training for teacher librarians, and a grants programme to all schools (Bundy, 2002; Ryan, 2018). In 1968, Trask's, School Libraries: A Report to the Nation, identified the evident lack of school library funding in Australia (Ryan, 2018).

Over the following years, federal funding was made available to develop primary and secondary school libraries in both government and non-government sectors. Grants to improve the quality of library staff, and guidelines for library resource facilities and services were introduced (Australian Schools Commission, 1979). After two decades of near universal school library provision, national sample surveys were conducted to establish standards, which were published by Curriculum Corporation in Learning for the Future: Developing Information in Schools (ASLA \& ALIA, 2001).

The 2011 Parliamentary Inquiry report (Australian Government, 2011) illustrated the library's role in supporting learning, literacy and reading, and acknowledged their contribution to national government initiatives such as Building the Education Revolution (BER), the Digital Education Revolution (DER) and the new Australian Curriculum (Hughes, Bozorgian \& Allan, 2014). During the same time, the Review of Funding for Schooling report identified issues such as under-funding (Gonski et al., 2011) and similar issues were identified through the Softlink 2010 Survey (Softlink, 2010). The Parliamentary Inquiry (Australian Government, 2011) recommended the need for research to identify the absence of "(a) mandatory standards for school library resourcing and staffing; and (b) regular and consistent nationwide reporting about school libraries" (Hughes, et al., 2014).

Keep in mind that this lack of accurate information and systematic monitoring of libraries, is in relation to what we do know about library provision in Australian schools. Further questions remain regarding schools without libraries or teacher librarians on staff.

Accordingly, this present study aims to gauge the nature of library provision and non-provision in schools, including identification of the various factors that support the establishment of a school library as well as identifying how information services are managed when there is no library provision. A literature review informed the development of a survey that aimed to overcome the issue of non-response bias and to address the absence of accurate information about the current 
nature of school libraries in Australia. While South Australia pioneered this study, limiting the scope of this report to schools in South Australia, there is opportunity to expand this study in other states and territories to gain a complete picture of school libraries Australia-wide.

\section{About the review of literature}

The overarching questions for this research relate to the profile of school library staffing, and the factors that influence school libraries and their staffing. A search for existing research literature relating to these topics was conducted to inform the design of the study, and provide background context for those reading this report. The review of literature was not limited to the South Australian context and includes Australian and international research published since 2010, showcasing examples of contemporary libraries that present the range of proactive and effective approaches to providing information resources in the $21^{\text {st }}$ century.

\section{Census approach through survey and desk review}

The 2011 Parliamentary Inquiry into School libraries and teacher librarians in 21st century Australia, identified a gap in information regarding school libraries, as cited by Hughes and colleagues (2014).

The Inquiry's concluding comment 6.12 states: There is a fundamental need to collate some hard data to ascertain how many teacher librarians there are in Australia's primary and secondary schools; to identify where the gaps are; and to start to extrapolate the links between library programs, literacy (especially digital literacy, which is as important as regular literacy and numeracy skills), and student achievement (House of Representatives, 2011, p. 118, in Hughes et al., 2014, pp. 5-6).

In Australia, there has been attempts at collecting information about school libraries in New South Wales, Gold Coast, and Western Australia (Hay \& Todd, 2010; Hughes, 2013a, 2013b; Merga, 2018; Merga, 2019) as well as nationally, in part, as a consequence of the Inquiry Report. However, most of the studies involved data collection through the teacher librarian and thus missed including data from schools with non-traditional models of library services. Table 1 presents a list of these studies undertaken in Australia since 2005. The outcome, was that for the numerous schools without a teacher librarian on staff or a physical library on site, schools were unlikely to participate, potentially leading to biased results (Merga, 2018).

A better understanding of the staff and resources of libraries in South Australian schools is long overdue, since none of the previous research initiatives have been conducted in South Australia. A shift in focus from a survey of teacher librarians to a survey of school leadership has also not been previously done. Accordingly, a census-style approach targeting school leadership in all South Australian schools has been chosen in order to overcome many of the limitations experienced in previous studies.

To this end, a working group was formed in late 2018, comprising of researchers from ACER and teacher librarians from SLASA, to design a census survey that would gather pertinent information from schools on the status of their libraries. The development of the survey and administration is detailed in Appendix A, with the resulting instrument presented in Appendix B. 
To supplement the census data, a desk review was also undertaken of the 'public facing' websites of all schools in South Australia in order to triangulate further hard evidence of a library from an independent source. The website search protocol is presented in Appendix C.

Table 1. List of other recent Australian studies focusing on school libraries

\begin{tabular}{|c|c|}
\hline Author & Key findings \\
\hline Merga, 2019 & $\begin{array}{l}\text { The Teacher Librarians as Australian Literature advocates in Schools (TLALAS) } \\
\text { project in Western Australia } \\
\text { - the role of teacher librarians in } 30 \text { schools in supporting struggling readers }\end{array}$ \\
\hline $\begin{array}{l}\text { Godfree \& Nielson } \\
2018\end{array}$ & $\begin{array}{l}\text { The results of ongoing studies into library staffing levels in Australian Capital } \\
\text { Territory (ACT) schools } \\
\text { - } \quad \text { government schools 2012-2017 } \\
\text { - } \quad \text { all sectors } 2017\end{array}$ \\
\hline $\begin{array}{l}\text { Merga \& Gardiner, } \\
2018\end{array}$ & $\begin{array}{l}\text { Most Australian schools may not have whole school literacy plans, policies and } \\
\text { agreement documents (PPADs) that support reading engagement } \\
\text { - Where PPADs did exist, these varied widely }\end{array}$ \\
\hline Merga, 2018 & $\begin{array}{l}\text { The Teacher Librarians as Australian Literature Advocates in Schools (TLALAS) } \\
\text { project } \\
\text { - data collected on site at } 30 \text { schools in Western Australia } \\
\text { - potential issues influencing teacher librarians' morale }\end{array}$ \\
\hline Weldon, 2016 & $\begin{array}{l}\text { Findings from the Staff in Australia's Schools (SiAS) survey of teachers and school } \\
\text { leaders } \\
\text { - During 2007-2013 about four to five per cent of primary teachers are seen } \\
\text { to be working in a library role, and about two to three per cent of secondary } \\
\text { teachers. } \\
\text { - Between } 2010 \text { and } 2013 \text { a greater number of teachers were employed in } \\
\text { library roles in high socio-economic (SES) schools }\end{array}$ \\
\hline $\begin{array}{l}\text { Hughes, 2013a, b; } \\
\text { Hughes et al., } 2013\end{array}$ & $\begin{array}{l}\text { The study on School Libraries, Teacher librarians and their Contribution to } \\
\text { Student Literacy in Gold Coast Schools } \\
\text { - school library provision and staffing } \\
\text { - the contribution of school libraries and teacher librarians to school students' } \\
\text { literacy development }\end{array}$ \\
\hline Softlink, 2010-18 & $\begin{array}{l}\text { Trends in budget allocation, staffing, facility resources } \\
\text { - Teacher librarian perceptions }\end{array}$ \\
\hline Hay \& Todd, 2010 & $\begin{array}{l}\text { The School Libraries Futures Project } \\
\text { - importance of school libraries; } \\
\text { - evidence of teacher librarian activities that support information literacy and } \\
\text { learning in New South Wales government schools } \\
\text { - limited evidence of impacts on student learning }\end{array}$ \\
\hline Combes, 2008 & $\begin{array}{l}\text { Australian School Libraries Research Project } \\
\text { Report 1: School libraries } \\
\text { - Age of library facilities, space, seating, ICT } \\
\text { - Library budget } \\
\text { Report 2: Teacher librarians } \\
\text { - Age, experience, qualifications of teacher librarians } \\
\text { - Professional development activities }\end{array}$ \\
\hline
\end{tabular}




\section{Who answered the census?}

The survey was administered in Term 32019 to the leadership of 728 schools in South Australia. All but 50 schools responded to the survey, and these schools were followed up with a brief phone call (see Appendix A). Most census surveys were completed by library staff (63\%), a quarter were completed by the school principal (24\%), with a few completed by school administration staff $(10 \%)$ or teachers $(8 \%)$. Twenty schools $(3 \%)$ selected the option declining to participate. More than one person could respond to the census, or the person responding could have multiple roles in the school. Note that principals were not specifically targeted or required to complete this survey, and delegation to the most knowledgeable person in the school leadership team was anticipated. During the data preparation process, the small number of schools with more than one response were combined into one record for the school, with views provided by library staff given preference where discrepancies occurred. Figure 1 presents the profile of respondents, some with multiple roles (resulting in a distribution of more than $100 \%$ ). That $87 \%$ of respondents were library staff or the principal, strengthens confidence in the results.

Figure 1. Profile of census respondents $(n=728)$

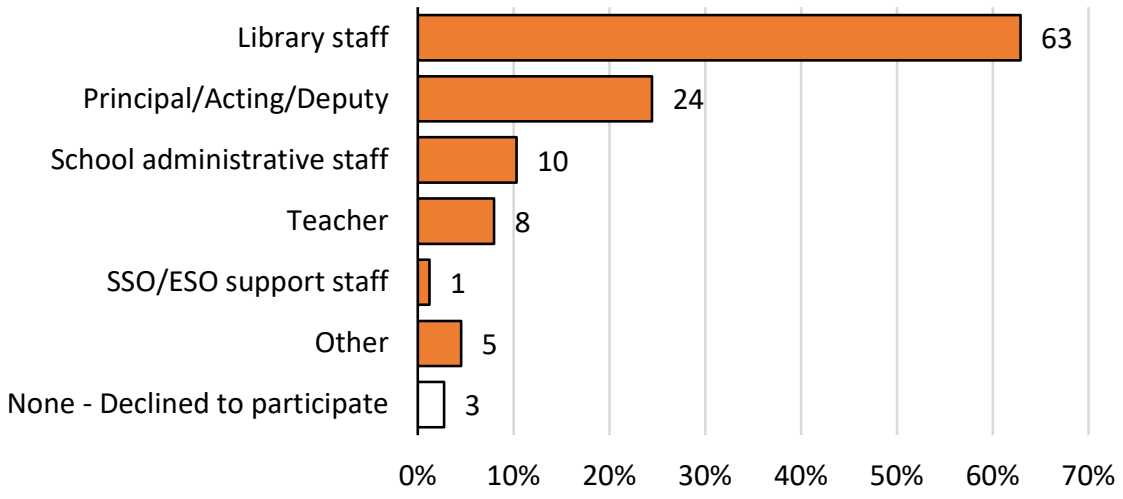

Although the study achieved census and involved every school, $10 \%$ of schools had incomplete surveys with missing data. Accordingly, the results from the census and website review, conducted during Term 3 2019, are based on the 90\% of schools with complete data, which provides representative and generalisable results in the South Australian context. These results and findings are presented in the remainder of this report, interwoven with the literature review.

\section{WHY A SCHOOL LIBRARY IS IMPORTANT}

\section{What is a school library?}

A school library, sometimes referred to in Australia as a resource centre, is an information space (physical and/or digital) where resources (e.g., books, e-books, journals, periodicals, magazines, pamphlets, games) on different subjects and curricula are made available on an equitable basis for the whole school community (Gordon, 2015; IFLA, 2015; Todd, 2015; Todd, Gordon \& Lu, 
2011). A school library is also a hub for research and inquiry, teaching and learning, and nurturing student wellbeing (APPGL, 2014; Curtis, 2017). The objective of a school library is to inform students and the school community and "develop information literate students who are responsible and ethical participants in society" (IFLA, 2015, p. 7). An effective school library is informational, transformational and formational, and thus the key to knowledge conception, production, dissemination and practice, and the development of information standards (Todd \& Kuhlthau, 2005). Todd (2015) provides the following description.

The school library offers a learning environment that is not based on "the right answer" prompted by rote learning, but on a more complex model of teaching and learning that is inquiry-driven and which embeds a range of information and digital literacies. (p. 13)

\section{Why is it important to have a good school library?}

Prior international research has demonstrated that effective school libraries and teacher librarians can have a positive impact on student achievement, whether measured through reading scores, literacy or learning outcomes (Dow \& McMahon-Lakin, 2012; Francis, Lance \& Lietzau, 2010; Hay, 2005; Hughes, 2013a, 2013b; Hughes et al., 2014; Lonsdale, 2003; Todd \& Kuhlthau, 2005). There is also evidence from Australian research that well-resourced libraries support improved student literacy outcomes (ASLA, 2013; Hughes, 2013b; Softlink, 2012, 2016). Research further suggests that this impact is significant and independent of socio-economic status (Lance \& Hofschire, 2012; Pennsylvania School Library Project, 2012). Studies have also shown that teacher librarians specialise in differentiated inquiry-based learning, which is a strong focus in the Australian Curriculum (Lupton, 2013). While staffing the library with qualified people is important, having a sufficient number of staff to run the library and information resources is also important.

Shaper and Streatfield (2012) report on the library as a safe-place, central to building relationships with students, particularly if the librarian is approachable. Furthermore, according to a UK report in 2014, school libraries not only influence students' literacy levels, enjoyment of reading, information literacy skills and access to knowledge, but also support their self-esteem, confidence, and sense of safety and wellbeing in the school community by acting as a 'safe haven' (APPGL, 2014).

\section{How visible is the school library on school websites?}

In South Australia, all schools have some form of website. This can range from a professionally authored site or a school-configured department template, through to a Facebook page. Typically, school websites have a clear marketing of information about facilities, policy, curricula and community, targeted at attracting families and informing the wider public. Regardless of the professional execution of a site, school websites typically reflect pride and what's valued by the school community. As such, it was hypothesised that library and information services valued by schools may be reflected their promotion on the school website. As Herring (2007) writes,

The most successful school library websites are those which are closely linked to and are visible as part of the school website. This indicates the value which the school places on the school library (p. 39). 
While most studies found in the literature review examined the effectiveness of a school library website (Herring, 2007; Shaper, 2014), few studies were found that investigated the promotion of the school library on the public-facing website (Chu, 2013; Killoran, 2018).

Accordingly, during the Term 32019 census a desk review was undertaken of the 'public facing' websites of all schools in South Australia to explore how schools were promoting their school library as a possible reflection of how valued the library was in a school. The resulting 'visibility' of school libraries is presented in Figure 2, with comparison by school type, sector, location and socio-economic status (SES).

Figure 2. Level of visibility of the 'library' on the school website

\begin{tabular}{|c|c|c|c|c|c|c|c|c|}
\hline & & 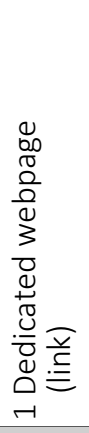 & 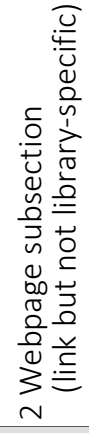 & 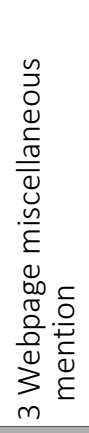 & 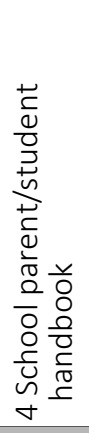 & 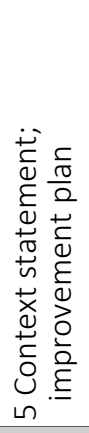 & 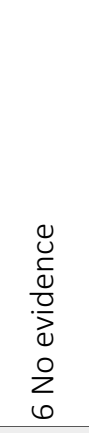 & 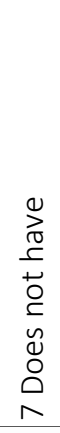 \\
\hline \multirow[t]{2}{*}{ OVERALL } & $\%$ & $16 \%$ & $11 \%$ & $27 \%$ & $24 \%$ & $16 \%$ & $6 \%$ & $1 \%$ \\
\hline & $n=728$ & 119 & 80 & 195 & 172 & 119 & 41 & 4 \\
\hline \multirow[t]{4}{*}{ TYPE } & Primary & $13 \%$ & $10 \%$ & $26 \%$ & $27 \%$ & $19 \%$ & $4 \%$ & $0 \%$ \\
\hline & Combined & $20 \%$ & $12 \%$ & $33 \%$ & $18 \%$ & $10 \%$ & $6 \%$ & $0 \%$ \\
\hline & Secondary & $26 \%$ & $12 \%$ & $27 \%$ & $17 \%$ & $10 \%$ & $7 \%$ & $1 \%$ \\
\hline & Special & $20 \%$ & $12 \%$ & $8 \%$ & $4 \%$ & $16 \%$ & $32 \%$ & $8 \%$ \\
\hline \multirow[t]{3}{*}{ SECTOR } & Government & $17 \%$ & $8 \%$ & $21 \%$ & $28 \%$ & $22 \%$ & $3 \%$ & $1 \%$ \\
\hline & Catholic & $16 \%$ & $17 \%$ & $39 \%$ & $17 \%$ & $2 \%$ & $9 \%$ & $1 \%$ \\
\hline & Independent & $12 \%$ & $20 \%$ & $41 \%$ & $9 \%$ & $5 \%$ & $13 \%$ & $0 \%$ \\
\hline \multirow[t]{3}{*}{ LOCATION } & Metropolitan & $19 \%$ & $16 \%$ & $27 \%$ & $20 \%$ & $11 \%$ & $6 \%$ & $1 \%$ \\
\hline & Regional & $13 \%$ & $5 \%$ & $25 \%$ & $29 \%$ & $22 \%$ & $6 \%$ & $1 \%$ \\
\hline & Remote & $15 \%$ & $2 \%$ & $27 \%$ & $24 \%$ & $27 \%$ & $6 \%$ & $0 \%$ \\
\hline SES & Low (1-3) & $12 \%$ & $9 \%$ & $26 \%$ & $25 \%$ & $21 \%$ & $7 \%$ & $1 \%$ \\
\hline \multirow{2}{*}{$\begin{array}{l}\text { SEIFA } \\
\text { within } \\
\text { state }\end{array}$} & Mid (4-7) & $18 \%$ & $12 \%$ & $23 \%$ & $27 \%$ & $15 \%$ & $5 \%$ & $0 \%$ \\
\hline & High (8-10) & $23 \%$ & $14 \%$ & $33 \%$ & $15 \%$ & $10 \%$ & $4 \%$ & $1 \%$ \\
\hline
\end{tabular}

The results of the website review, presented in Figure 2, show that for $16 \%$ of schools, the library has a dedicated webpage with obvious direct link from the main menu. These schools tend to be metropolitan secondary government schools in high SES communities. One in ten schools (11\%) have at least a webpage subsection, usually on the facilities page, which might include a menu link to the library section. These schools tend to be metropolitan Independent schools.

Two-thirds of schools, while having evidence of a library, do not have a page or section dedicated to the library on their school public-facing website. Miscellaneous or passing reference to a library 
was found on $27 \%$ of websites, mainly non-government schools, with evidence typically found on the About Us page, the principal's welcome, curriculum descriptions, or in the photo gallery. For $24 \%$ of schools, the first reference to a library is found in the school parent/student handbook. The profile of these schools tends to be government primary school in regional communities. As a final source of evidence, once all other avenues had been explored, school administrative documents were investigated. These include school context statements, improvement plans and annual reports. This is the case for $16 \%$ of schools, which are more likely to be government primary schools in remote communities.

For $7 \%$ of schools, the website or available school documentation shows no evidence of a library, suggesting that these schools may not have an on-site library. Of these, $0.5 \%$ of schools provide confirmatory evidence that a physical library is not on the school site. For example, during the investigation, two of the 54 school site maps that were found on websites did not show the facilities of a library resource centre. These tend to be Special schools catering for students with disability or outreach centres for marginalised youth. However, at least one metropolitan high school and primary school do not have a traditional school library - by design. This may be the start of a trend in school design in Australia. For example, in lieu of a centralised whole-school library, the new McAuley Community primary school in Hove SA has shelves of books distributed throughout multi-classroom-sized learning spaces called 'neighbourhoods', each with its own book-borrowing system (Williams, 2020).

How a school refers to their library was also captured as part of the investigation and is summarised in the word-cloud and graph in Figure 3. The term 'Library' is the main description for $60 \%$ of schools, followed by 'Resource Centre' (16\%) and combinations like 'Library or Information Resource Centre' (8\%). One in 20 schools refer to their town's 'Community Library' as a shared facility that their school uses. Several schools (1\%) refer to the 'Learning hub' while a further $5 \%$ of schools have a specific name, like 'The hive', the 'Cybrary', or named after someone significant in the community. Schools co-situated with a university, use the 'University library', working along-side university students. According to this approach, Figure 2 also suggests that $7 \%$ of schools do not have a library or access to a community or mobile library. To what extent this is an accurate profile of South Australian school libraries, viewed through the lens of publicfacing school websites, will be examined in relation to the census data. 
Figure 3. How school websites refer to their library $(n=728)$

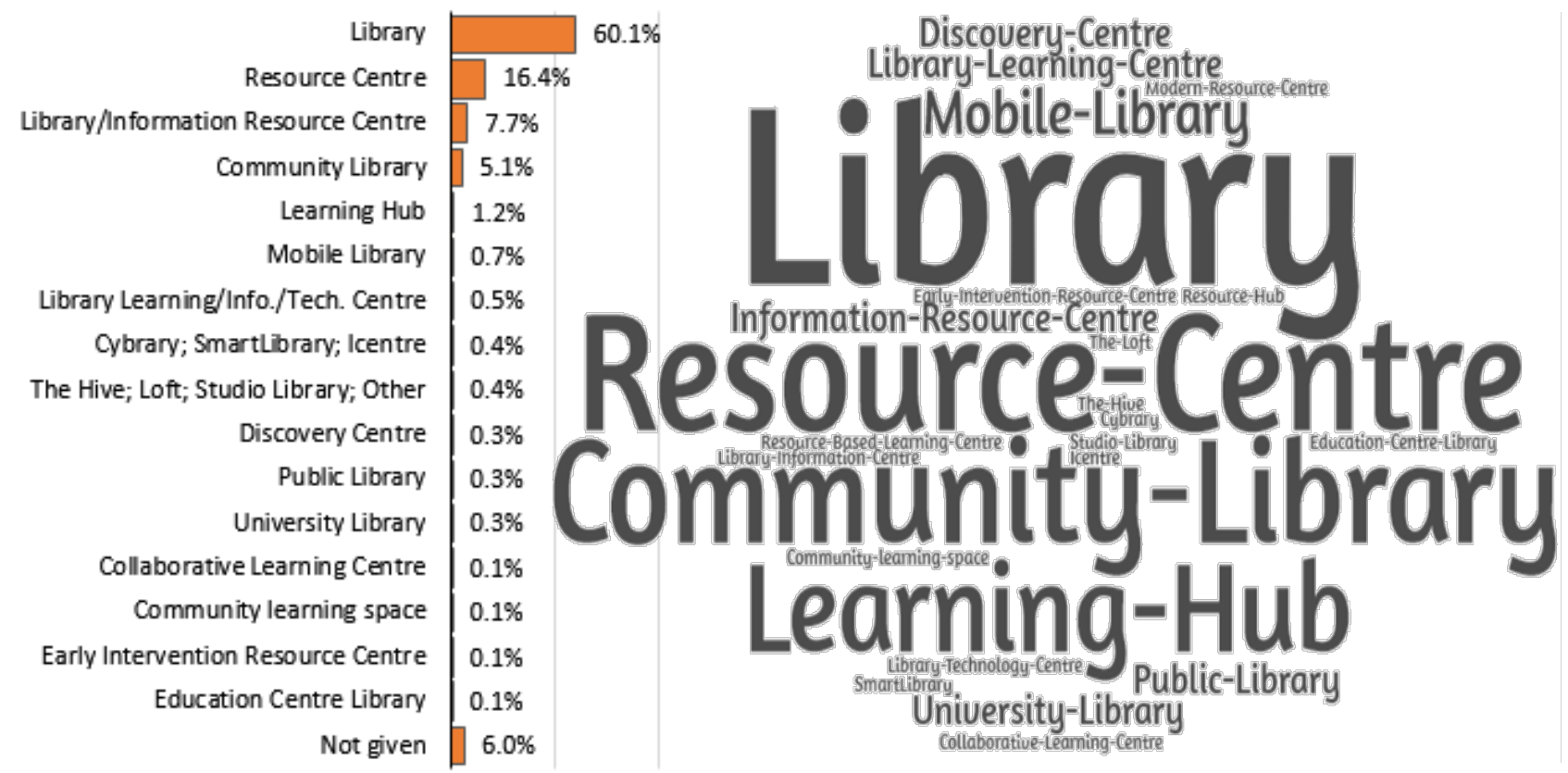

\section{Factors that contribute to an effective school library}

The American Library Association (ALA, 2019) states that highly effective school libraries have a common set of philosophical characteristics that influence 'inputs' such as staffing, instructional programs, use of technology and curriculum content, resources, professional development, budget allocation, and IT infrastructure. According to the International Federation of Library Associations,

Meeting all the standards for funding, for technology, for collections, for staffing, and for facilities, does not necessarily guarantee the best teaching and learning environment. What is more important is the way that the members of the school community think about school libraries: working in service of the moral purpose of school libraries (i.e., making a difference in the lives of young people) and of the educational purpose of school libraries (i.e., improving teaching and learning for all). Facilities, collections, staff, and technology are only means to that end (IFLA, 2015, p. 13).

Creative use of space and resources, support from school leadership, and knowledgeable leaders who support collaboration between teachers and teacher librarians are important factors that contribute to the effectiveness of a library (Todd, et al., 2011). If schools have transformed since the advent of the internet, what are the factors that contribute to an effective contemporary school library?

Traditionally, the school library as a facility involved the physical space, measured in square metres or the number of people that could be accommodated in that space. Today, the facility includes both physical and virtual learning environments; including the library website, research guides, help materials, reading lists and any other materials that address literacy and learning (Gordon, 2015). Likewise, the number of physical volumes in a library collection, or the average 
copyright date as the typical measure of the collection, is no longer the only measure of effective provision of resources. Digital information sources are a major part of today's library collections. With regards to staffing, the number of professional full-time library staff is only one consideration. Staff teams may include additional instructional and technology expertise that deliver help, formally and informally, in direct and indirect ways (ASLA \& ALIA, 2001). Moreover, the budget for resourcing the curriculum goes beyond a fixed allocation of school funds and includes an increasing component of leasing and subscription costs. Figure 4 illustrates these key factors and their link to the overall quality of the school library, captured in the following statement by Scholastic (2008), and provides the structure for which the census results are presented.

Effective school libraries are much more than books. They are learning hubs, each with a full range of print and electronic resources that support student achievement. Today's school libraries must be gathering places for people of all ages and all interests to explore and debate ideas. School libraries have the most significant impact on learning outcomes when they are supervised by a library media specialist, who works collaboratively with teachers, to help all students develop a love of reading, become skilled users of ideas and information, and explore the world of print and electronic media resources (Scholastic, 2008, p. 6).

Figure 4. Key factors influencing the quality of a school library

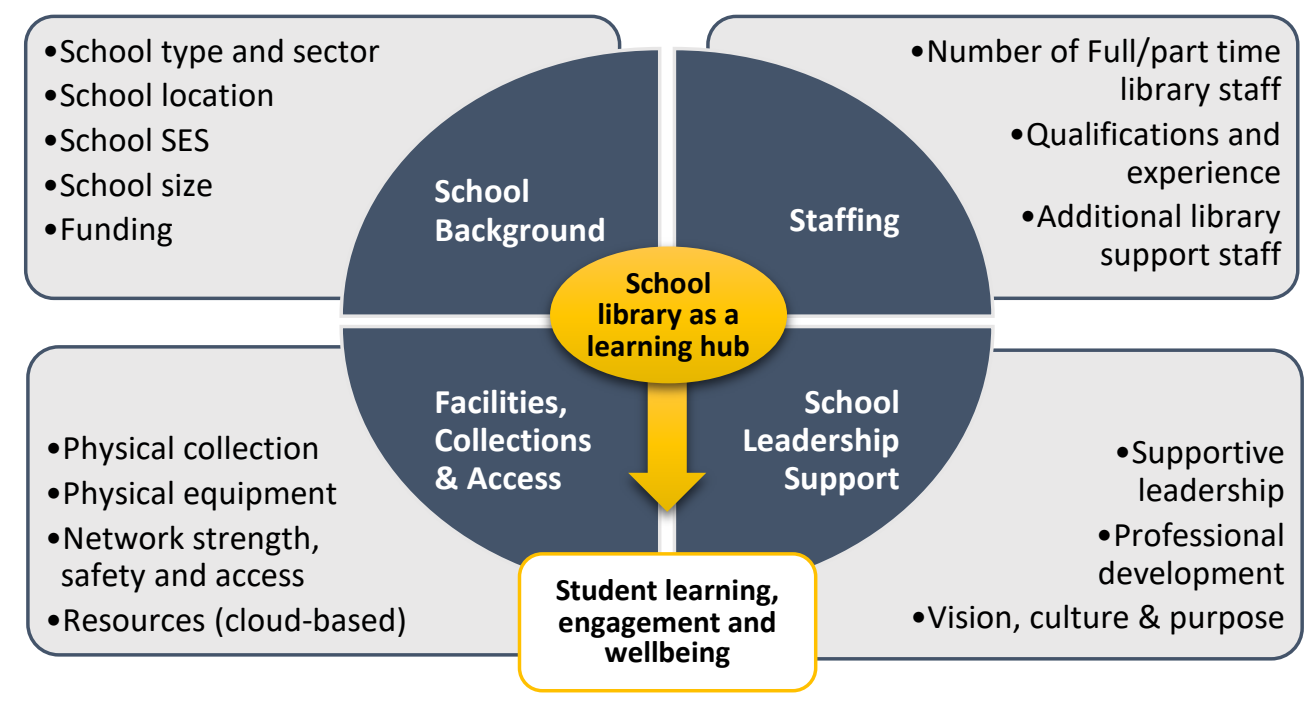




\section{SCHOOL BACKGROUND AND FUNDING}

In Australia, the type of school, its location and the socio-economic background of the community in which it is located, can all influence the type of families the school attracts, which in turn affects funding. The local school context or community background often influences the legislation, economic development, and educational infrastructure in that area which can have an impact on the condition of the school libraries (IFLA, 2015). Some 70\% of Australian schools are government schools, established and managed by state and territory governments through their education departments. The remaining are non-government schools, which includes Catholic (18\%) and Independent (12\%) schools (ACARA, 2019). The characteristics of the students vary across these three sectors, as do the resources available to and used by schools in each sector.

\section{The South Australian context}

The census approach used in this study presents, for the first time in Australia, a complete profile of schools in one state, South Australia. The demographic profile of the 728 South Australian schools is presented in Figure 5, along with comparison to the national average based on ACARA 2018 school list data ( $n=9,535$ schools). Over half of schools are found in metropolitan areas in South Australia with marginally higher socio-economic status distribution than nationally across Australia.

The type of school, its size in terms of student population, and the year levels it serves are all factors that influence the school library. While in most Australian states, primary schools start with pre-Year 1 and finish with Year 6, South Australian primary schools have until recently generally retained Year 7 students. Recent policy change will see Year 7 students enrolled as secondary students in South Australia. A combined school has student enrolments from both primary and secondary year levels. In South Australia there are 151 combined schools (ACARA, 2019 , p. 15). Many of these combined schools are rural schools, and 43 of these schools have a school community library - a unique feature of the South Australian government's provision of library services (Libraries Board of South Australia, 2019, p. 13). There are also 24 Special schools in South Australia that accommodate students with disability (ACARA, 2019, p. 15), and other schools, such as Open Access College, that cater for students with needs that cannot be met by mainstream schooling or for students in very remote areas. Provision of a school library service may look quite different according to the type and size of school it serves. How these schools provide library services in an increasingly digital world is the driving question behind this study. 
Figure 5. Characteristics and locations of South Australian schools

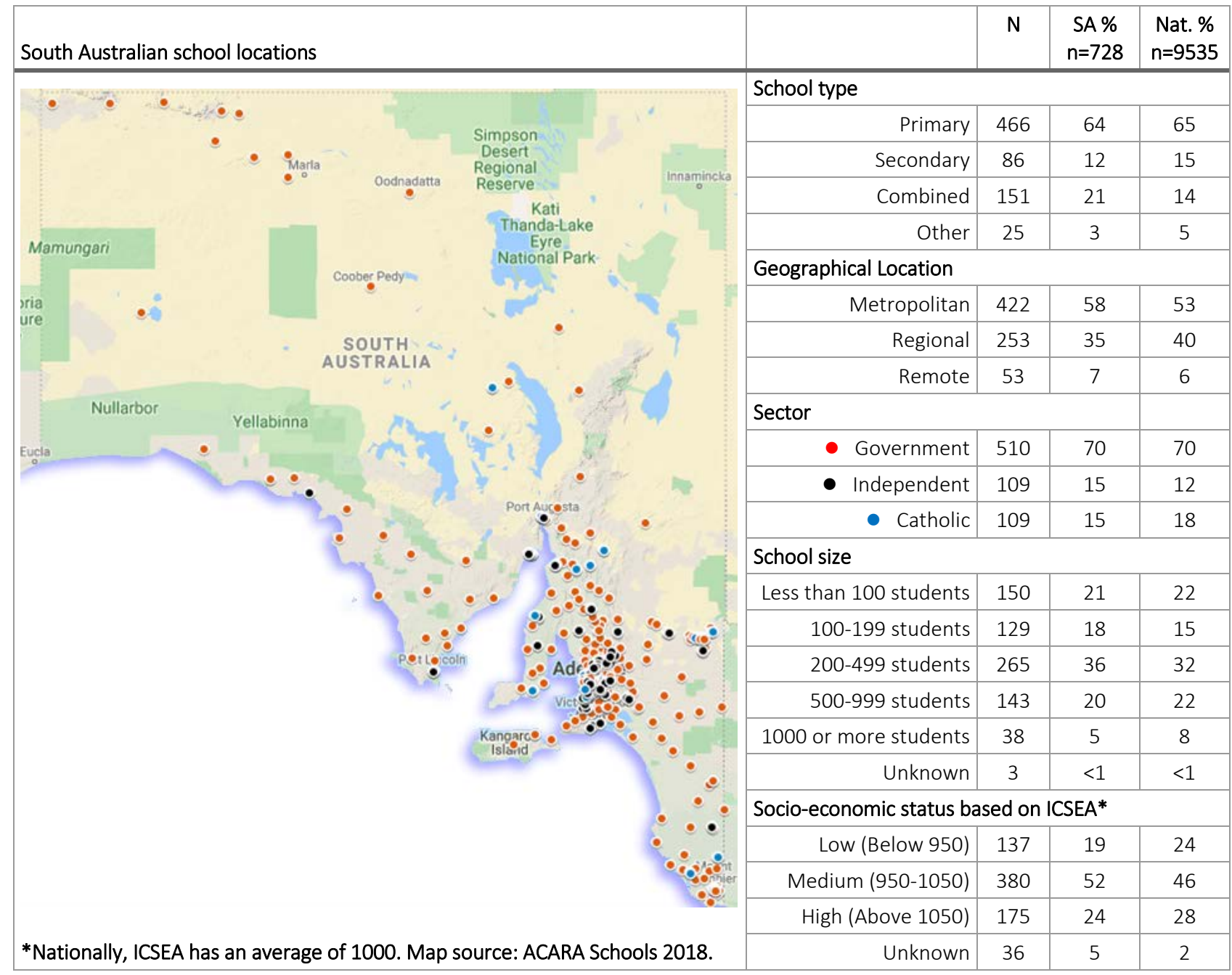

The area where a school is located is also an indicator of the student's background as measured by the Socio-Economic Indexes for Areas (SEIFA), which ranks areas in Australia according to relative socio-economic advantage and disadvantage. A similar scale, the Index of Community Socio-Educational Advantage (ICSEA) developed by ACARA, is widely used across Australia as a proxy for socio-economic-status and takes into consideration factors such as geographical location, proportion of Indigenous students, parents' occupation and parents' education.

Research suggests that students who experience multiple factors of disadvantage and marginalisation (e.g. remoteness, low socioeconomic status, culturally diverse, disability, indigeneity) are at higher risk of poor academic and social outcomes (Gonski et al., 2011). Government schools tend to enrol a greater proportion of educationally disadvantaged students because affluent families tend to send their child to non-government schools or select-entry government schools. These families are also more likely to have books in the home and value reading, which influences school-community attitude about the importance of access to books and reading behaviour (Gonski et al., 2011). 


\section{Funding}

Of all the background factors reported in the national and international literature, the one impacting school libraries most directly, is funding and budget constraints (APPGL, 2014; Scholastic, 2016; Softlink, 2016; Clark \& Teravainen, 2017). Research argues that sustained investment in school libraries is essential for the advancement of literacy and better learning outcomes (Softlink, 2018). A recent study conducted with schools in Western Australia raised concern about the impact of reduced funding.

Unfortunately, in a number of the libraries that took part in the study, funds and staffing had been depleted to the point that to continue to perform practices to support literacy and literature learning was becoming increasingly challenging for teacher librarians. (Merga, (2018, p. 12)

Analysis of data from Softlink surveys for Australian Schools suggest that from 2010 to 2014 only $17-20 \%$ of schools reported budget increases while $25-30 \%$ of schools reported budget decreases over the time frame (Softlink, 2016). A shortage or inadequacy of funding for resources needed to allow teachers to use the opportunities libraries provide to improve educational outcomes, is an obvious barrier to schools. For example, Figure 6 presents recent TALIS results for Australia in 2013 and 2018 (Thomson \& Hillman, 2019). It shows the percentage of secondary school principals reporting the lack of resources hindering instruction 'to some extent' or 'a lot' in their school. Principals reported an increase in the shortage of digital technology for instruction between 2013 (8\%) and 2018 (12\%), and the inadequacy of library materials between 2013 (6.5\%) and 2018 (7\%). Although not a marked difference, this may be an early indication that Australian schools, broadly, are beginning to experience inadequate access to instructional digital technologies and library materials.

Figure 6. Percentage of secondary school principals reporting that lack of resources hinder instruction 'to some extent' or 'a lot' in their school

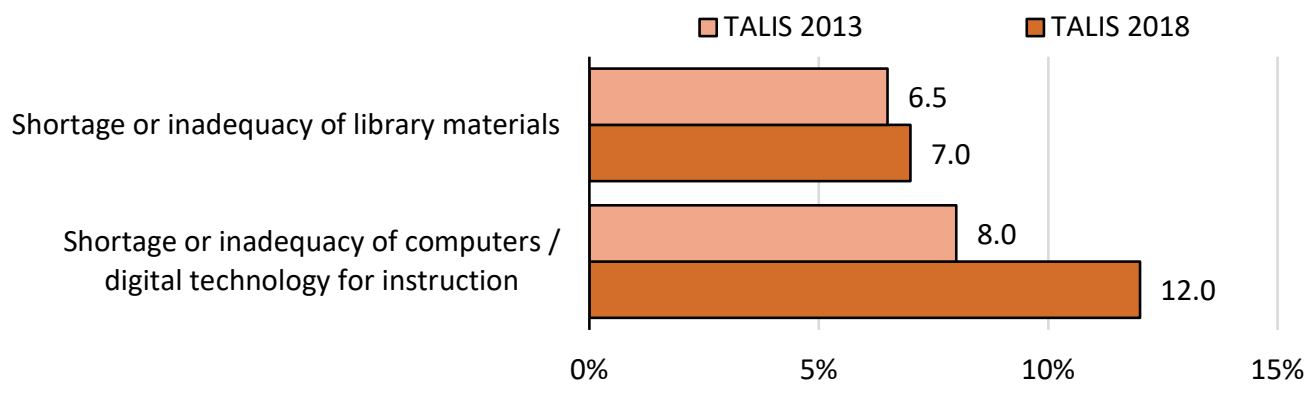

\section{School budgets fund school libraries}

The census results confirm that the majority of school libraries (98\%) are funded via school budget allocation, which have to compete with all other demands on the limited school budget. As Figure 7 shows, a further $12 \%$ of schools fundraise (including book sales) to supplement the budget allocation. A small number of schools also access other funding sources, along with voluntary contributions paid by parents or other donations. 
Figure 7. Percentage of schools according to how the school library funded ( $n=583$ )

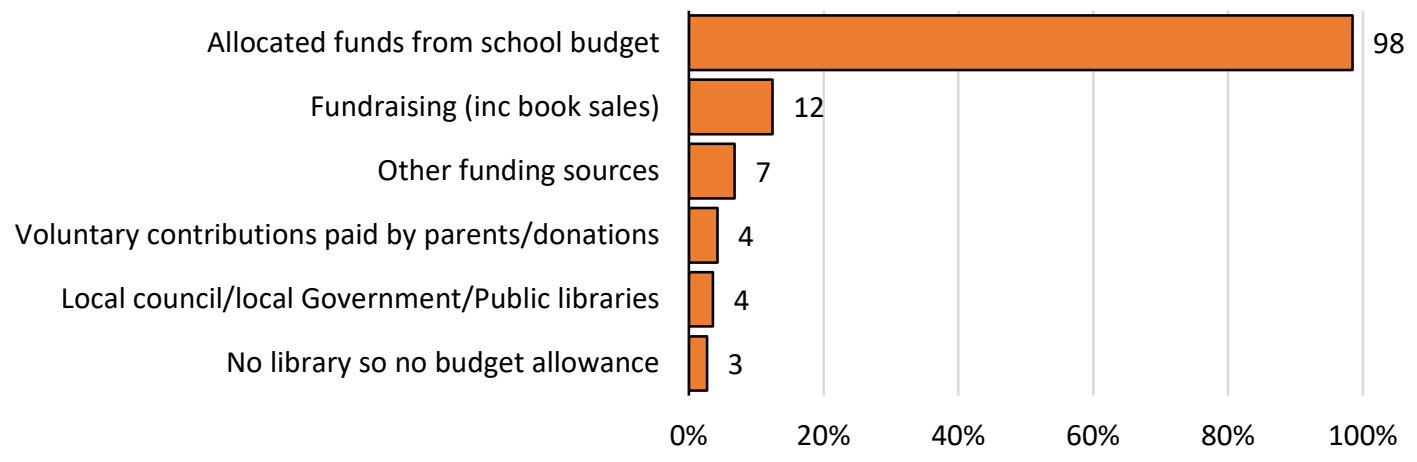

\section{School library funding varies widely across schools}

Responses to the census questions related to learning resource services available in the school and those related to the budget allocated for resourcing the school library, show that different schools have widely varying funding. Library resource budgets cover different resources in different schools. For example, some library budgets cover multiple copy collections, such as literacy resources, some don't. Some include the cost of infrastructure such as the library management system, some don't. While this makes it difficult to compare school library resource budgets with any degree of detail, it is clear that there is a major inequity in the funding available across South Australian schools.

Information collected through the census regarding the approximate amount of a school's recurrent budget is allocated to supporting and resourcing the library, not including staff salaries and facilities, is presented in Figure 8. Budgets range from less than $\$ 1000$ to greater than $\$ 50000$. About two-thirds of schools (65\%) range in budget from $\$ 2501$ to $\$ 20000$, with a median budget of about $\$ 7500$. Smaller primary and remote schools are more likely to be at the lower end of the range. High socio-economic status schools are more likely to be at the upper end of the range. 
Figure 8. Percentage of schools in each school size category allocating the approximate amount of recurrent budget to supporting and resourcing the library $(n=538)$

\begin{tabular}{|c|c|c|c|c|c|c|c|c|}
\hline $\begin{array}{l}\text { School Size } \\
\text { (enrolments) } \\
\text { Library budget }\end{array}$ & $\begin{array}{l}\stackrel{8}{0} \\
\text { zon } \\
\frac{0}{0} \\
\infty\end{array}$ & 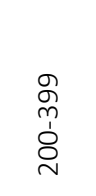 & $\begin{array}{l}\text { જે } \\
\text { ஸे } \\
\text { ठ } \\
\text { }\end{array}$ & $\begin{array}{l}\text { बे } \\
\text { †े } \\
8 \\
0\end{array}$ & $\begin{array}{l}\text { बे } \\
\text { के } \\
\text { ठ } \\
\infty\end{array}$ & $\begin{array}{l}\text { જે } \\
\text { ने } \\
\overrightarrow{1} \\
\text { } \\
\text { ઠ }\end{array}$ & 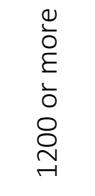 & Average overall \\
\hline Less than $\$ 1,000$ & $15.7 \%$ & $0.7 \%$ & $3.4 \%$ & & & & & $7 \%$ \\
\hline$\$ 1,001-\$ 2,500$ & $27.4 \%$ & $5.9 \%$ & $2.2 \%$ & $1.8 \%$ & & & & $12 \%$ \\
\hline$\$ 2,501-\$ 5,000$ & $28.9 \%$ & $23.0 \%$ & $5.6 \%$ & $5.5 \%$ & & & & $18 \%$ \\
\hline$\$ 5,001-\$ 7,500$ & $14.2 \%$ & $23.0 \%$ & $13.5 \%$ & & $7.4 \%$ & & $4.8 \%$ & $14 \%$ \\
\hline$\$ 7,501-\$ 10,000$ & $8.1 \%$ & $23.0 \%$ & $23.6 \%$ & $9.1 \%$ & $3.7 \%$ & $7.1 \%$ & $4.8 \%$ & $14 \%$ \\
\hline$\$ 10,001-\$ 20,000$ & $3.6 \%$ & $18.5 \%$ & $29.2 \%$ & $41.8 \%$ & $44.4 \%$ & $42.9 \%$ & $9.5 \%$ & $19 \%$ \\
\hline$\$ 20,001-\$ 30,000$ & $2.0 \%$ & $5.9 \%$ & $16.9 \%$ & $18.2 \%$ & $11.1 \%$ & $21.4 \%$ & $19.0 \%$ & $9 \%$ \\
\hline$\$ 30,001-\$ 40,000$ & & & $2.2 \%$ & $14.5 \%$ & $7.4 \%$ & & $28.6 \%$ & $3 \%$ \\
\hline$\$ 40,001-\$ 50,000$ & & & $2.2 \%$ & $3.6 \%$ & $7.4 \%$ & $14.3 \%$ & $19.0 \%$ & $2 \%$ \\
\hline Greater than $\$ 50,000$ & & & $1.1 \%$ & $5.5 \%$ & $18.5 \%$ & $14.3 \%$ & $14.3 \%$ & $3 \%$ \\
\hline
\end{tabular}

When these results are converted to a dollar figure per student as in Figure 9, the discrepancy between schools becomes marked. In the outlier schools, there are schools budgeting $\$ 1.00$ per students, while others budget $\$ 250$ per student. The fact that $15 \%$ of small schools budget $\$ 5$ per student for library resources is of particular concern, as this cannot provide an adequate collection of literacy, literature and learning resources.

Figure 9 Average library budget per student (\$)

\begin{tabular}{|c|c|c|c|c|c|c|c|}
\hline $\begin{array}{l}\text { School Size } \\
\text { (enrolments) } \\
\text { Library budget }\end{array}$ & $\begin{array}{l}\text { O } \\
\text { } \\
3 \\
\frac{0}{\mathscr{D}} \\
\infty\end{array}$ & $\begin{array}{l}\text { ळે } \\
\text { } \\
\text { ○े } \\
\text { ठ }\end{array}$ & 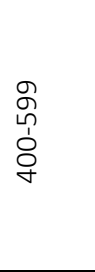 & $\begin{array}{l}\text { જે } \\
\text { ஸे } \\
8 \\
8\end{array}$ & $\begin{array}{l}\text { ळ } \\
\text { চे } \\
\text { ठे }\end{array}$ & 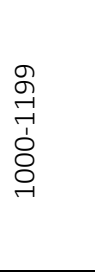 & 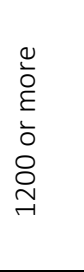 \\
\hline Less than $\$ 1,000$ & 5 & 2 & 1 & & & & \\
\hline$\$ 1,001-\$ 2,500$ & 18 & 6 & 4 & 3 & & & \\
\hline$\$ 2,501-\$ 5,000$ & 38 & 13 & 8 & 5 & & & \\
\hline$\$ 5,001-\$ 7,500$ & 63 & 21 & 13 & & 7 & & 5 \\
\hline$\$ 7,501-\$ 10,000$ & 88 & 29 & 18 & 13 & 10 & 8 & 7 \\
\hline$\$ 10,001-\$ 20,000$ & 150 & 50 & 30 & 21 & 17 & 14 & 13 \\
\hline$\$ 20,001-\$ 30,000$ & 250 & 83 & 50 & 36 & 28 & 23 & 21 \\
\hline$\$ 30,001-\$ 40,000$ & & & 70 & 50 & 39 & & 29 \\
\hline$\$ 40,001-\$ 50,000$ & & & 90 & 64 & 50 & 41 & 38 \\
\hline $\begin{array}{r}\text { Greater than } \\
\$ 50,000\end{array}$ & & & 100 & 71 & 56 & 45 & 42 \\
\hline
\end{tabular}


When asked if the school's recurrent budget had changed from the previous year, $62 \%$ of respondents said it did not change. Figure 10 presents the results and shows that $20 \%$ of schools, mainly those with an on-site library and with virtual or mobile access, report that their recurrent budget increased. The main reasons given for an increased recurrent budget were increased costs relating to databases, subscriptions, inflation, purchasing more resources, including books and furniture, and increased student enrolments, particularly in larger schools. The following comments provide examples of reasons behind the budget increase.

"Cost of books purchased each year increases- budget adjusted accordingly"

"Database subscriptions increased"

"To include all licencing fees, subscriptions, standing orders and general expenses"

Figure 10. Percentage of schools in each school size category indicating if the school's recurrent budget changed from the previous year $(n=533)$

\begin{tabular}{|c|c|c|c|c|c|c|c|c|}
\hline $\begin{array}{r}\text { School Size } \\
\text { (enrolments) }\end{array}$ & $\begin{array}{l}\stackrel{ }{D} \\
\text { } \\
3 \\
\frac{0}{0} \\
\infty\end{array}$ & 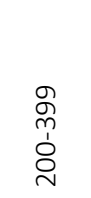 & 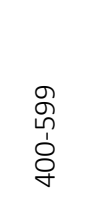 & $\begin{array}{l}\text { ब } \\
\text { 1 } \\
8 \\
0\end{array}$ & $\begin{array}{l}\text { ब } \\
\text { б } \\
\text { ঠి } \\
\varnothing\end{array}$ & 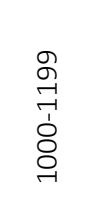 & 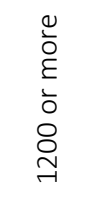 & Average overall \\
\hline Library budget increased & $14.1 \%$ & $16.1 \%$ & $16.7 \%$ & $25.9 \%$ & $40.7 \%$ & $14.3 \%$ & $40.0 \%$ & $\mid 19 \%$ \\
\hline Library budget did not change & $66.5 \%$ & $65.0 \%$ & $61.1 \%$ & $55.6 \%$ & $44.4 \%$ & $57.1 \%$ & $35.0 \%$ & $62 \%$ \\
\hline Library budget decreased & $19.4 \%$ & $19.0 \%$ & $22.2 \%$ & $18.5 \%$ & $14.8 \%$ & $28.6 \%$ & $25.0 \%$ & $20 \%$ \\
\hline
\end{tabular}

One of the main reasons for a budget decrease, reported by $20 \%$ of schools, is due in part to decreased student enrolments. Moreover, in the changing educational landscape in South Australia, reduced student enrolments may be a particular challenge for primary schools due to Year 7 (currently the final year in government primary schools) making the move in 2022 to become the first year in secondary school. Other reasons given for a decreased budget are associated with budget cuts or budget re-allocation to other priorities.

"Budget cuts across the whole school"

"Slight decrease in funds allocated to Textbook replacement due to cost cutting in various areas around the school"

"The budget is based around student numbers which has been declining"

"Year 7 move to secondary school, decreased school budget so no increase in library funding" 


\section{STAFFING}

Staffing decisions in school libraries are made based on local context, legislation, economic development, and educational infrastructure (IFLA, 2015). For South Australia the most recent document that deals with staffing of school libraries is the AEU SA (2013) School Library Staffing Policy, which is based on the South Australian Department of Education's (2000) document Recruitment placement and promotion policies, procedures and forms for schools and preschools. The AEU SA (2013) school library staffing policy focuses on school size and recommends that schools with 500 students should have a full-time teacher librarian to adequately support student and teacher needs (see Appendix D). The AEU SA (2013) describes the role of the teacher librarian.

As teachers they work with individual students, groups and classes to embed information literacy skills and literature-based teaching into inquiry units and class programs. They collaborate with teachers to plan, teach and evaluate these programs. They provide whole school leadership in literature programs that foster a love of reading, as well as information literacy, including digital literacy (p. 1).

\section{Which schools currently have a staffed school library?}

Most school libraries employ a teacher librarian whose role is central to the effectiveness of the library. However, a teacher librarian alone is usually not sufficient to effectively manage all the physical and digital collections, especially if the library is a large one over multiple sites. Welltrained and energetic teacher librarians with good specialist knowledge can increase the effectiveness of school outcomes by collaborating with teachers to support curriculum goals (Clark \& Teravainen, 2017; Ofsted, 2006; Scholastic, 2016). A UK based survey found that in the best schools, librarians were given the status and responsibility appropriate to their important middle management role (Ofsted, 2006).

The ACT Department for Education (2019, p. 11) stresses the importance of a well-staffed library, stating that, "Schools that invest in well-staffed school libraries reap the benefits of quality services and resourcing, ensuring their staff and students are best equipped for the digital age".

When investigating if schools have someone to manage the library collection and to select resources, Figure 11 shows that $94 \%$ of schools do. Having someone to manage the library collection is closely associated with library-type and the school context. Schools with only access to a mobile library or off-site community library, along with those that have no library, are more likely to not have someone to manage a library collection. Primary and combined K-12 schools with an on-site physical library, located in metro or regional communities of medium SES status are more likely to have a staff member managing the library, as are larger schools with recurrent budget allocation of over $\$ 2500$. 
Figure 11. Does your school currently have someone to manage a library collection? Yes

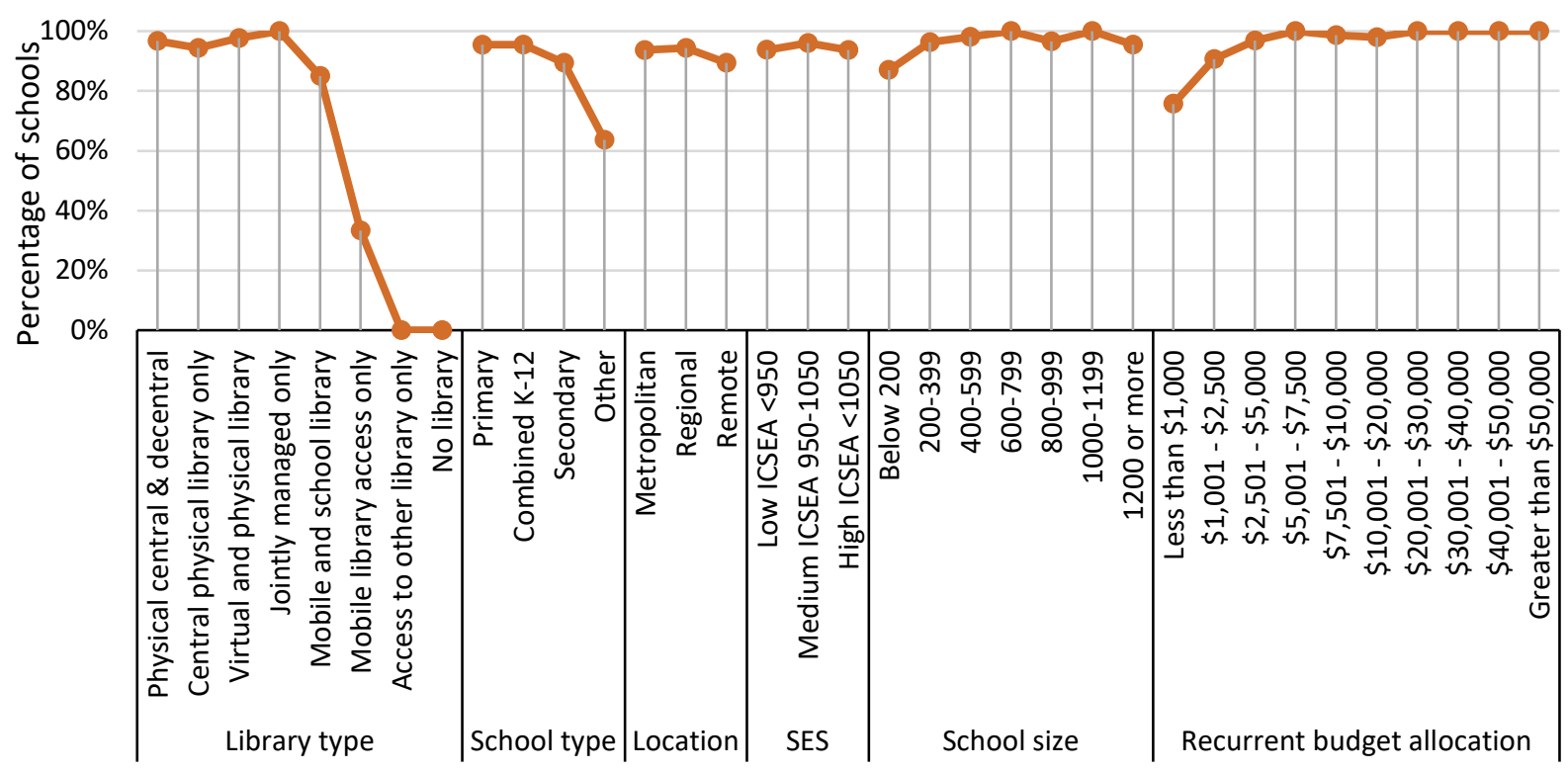

\section{Most staff managing school libraries are not library-qualified}

Schools vary significantly on library staffing in terms of full-time equivalent (FTE) staff and their qualifications. The review of literature found that in some states, government schools tend to have fewer and less well-qualified library staff than non-government schools (Merga, 2018; Hughes, 2013a). Non-government schools also tend to have more library staff overall including paraprofessional library technicians or administrative assistants, as well as a teacher librarian (Hughes, 2013a). The 2011 Inquiry into School libraries and teacher librarians in 21st century Australia, identified an information gap about provision and staffing of school libraries across Australian schools (Hughes et al., 2014). As a result, a report on the Staff in Australia's Schools (SiAS) survey of primary and secondary teachers analysed data from 2007, 2010 and 2013, and found evidence of fewer primary school teachers in library settings, less teachers working in libraries in low SES schools compared to high SES schools; and also reported that over one-third of primary teachers and one-quarter of secondary teachers working in school libraries had no tertiary degree in that area (Weldon, 2016; Mitchell \& Weldon, 2016). A study in the Gold Coast region of Queensland identified that while non-government schools had at least one part-time teacher librarian, many government schools had no teacher librarian (Hughes, 2013a).

In the same study (Hughes, 2013a) it was found that two of these government school libraries were run by library assistants with no professional qualifications in education or librarianship, three were run by a teacher (without librarianship qualification), and one was run by a library technician (with a Certificate IV but without specialised library or teaching degree).

Results from this census suggest that of those South Australian schools that do have someone to manage library resources, less than half of these have a library qualification, either as a teacher librarian (23\%) or a library-qualified SSO/ESO (20\%). Over one-third of those managing the school library are SSO/ESO with no formal library qualifications (36\%) and one in ten are teachers (12\%). Figure 12 presents the results. 
Figure 12. What is the background of the person who manages the library? ( $n=608)$

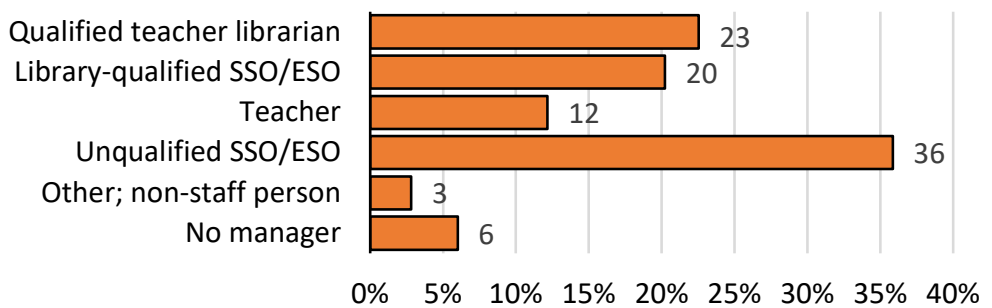

\section{Library staff qualifications matter}

Recent research from the US suggests that students' reading, writing, and graduation rates improve where schools employ registered teacher librarians (Scholastic, 2016; Lance \& Kachel, 2018). Prior research has also shown that having a well-staffed library with full-time professional librarians and support staff, have greater impact on student academic performance (Scholastic, 2008, 2016; Clark \& Teravainen, 2017).

In order to examine the relationship with the qualification of the person managing the library in the South Australian context, we linked schools' student NAPLAN 2018 literacy achievement data. Figure 13 shows that student literacy outcomes vary by Year level and by qualification of the person managing the library. However, these apparent trends in achievement may also be influenced by socio-economic background.

Accordingly, one-way ANCOVAs were conducted to test for an interaction effect between library manager type and socioeconomic status (SES) on students' averaged reading, writing, spelling, grammar and punctuation outcomes at Years 3, 5, 7 and 9. Statistically significant differences in student literacy achievement were found between schools grouped by the type of library manager they had, even after controlling for SES. For Year 3 literacy, the resulting one-way ANCOVA $(F(4,441)=3.216, p=0.013)$ was equivalent to one months' additional learning (effect size $=0.028$ ) for students in schools with a qualified teacher librarian. There was also a statistically significant effect of manager type on Year 5 literacy, accounting for $\operatorname{SES}(F(4,451)=3.451, p=$ 0.009), equivalent to one-months learning (effect size $=0.030$ ). The association was less apparent in Year 7 students $(F(4,426)=2.199, p=0.068)$ and was not statistically significant. However, the strongest association between library manager type and student literacy achievement was evident in the Year 9 cohort $(F(4,170)=5.492, p<0.001)$, equivalent to two months' additional learning (effect size $=0.114$ ) for students in schools with a qualified teacher librarian (Evidence for Learning, 2020). While these effects are very small, with about $30 \%$ of the variance in student achievement accounted for by SES, the evidence does support other research (Lance \& Kachel, 2018). The findings suggest that having a qualified teacher librarian on staff to manage the library and information services, support curriculum, and promote a love of reading, does benefit student literacy outcomes up to two months' additional learning gain. 


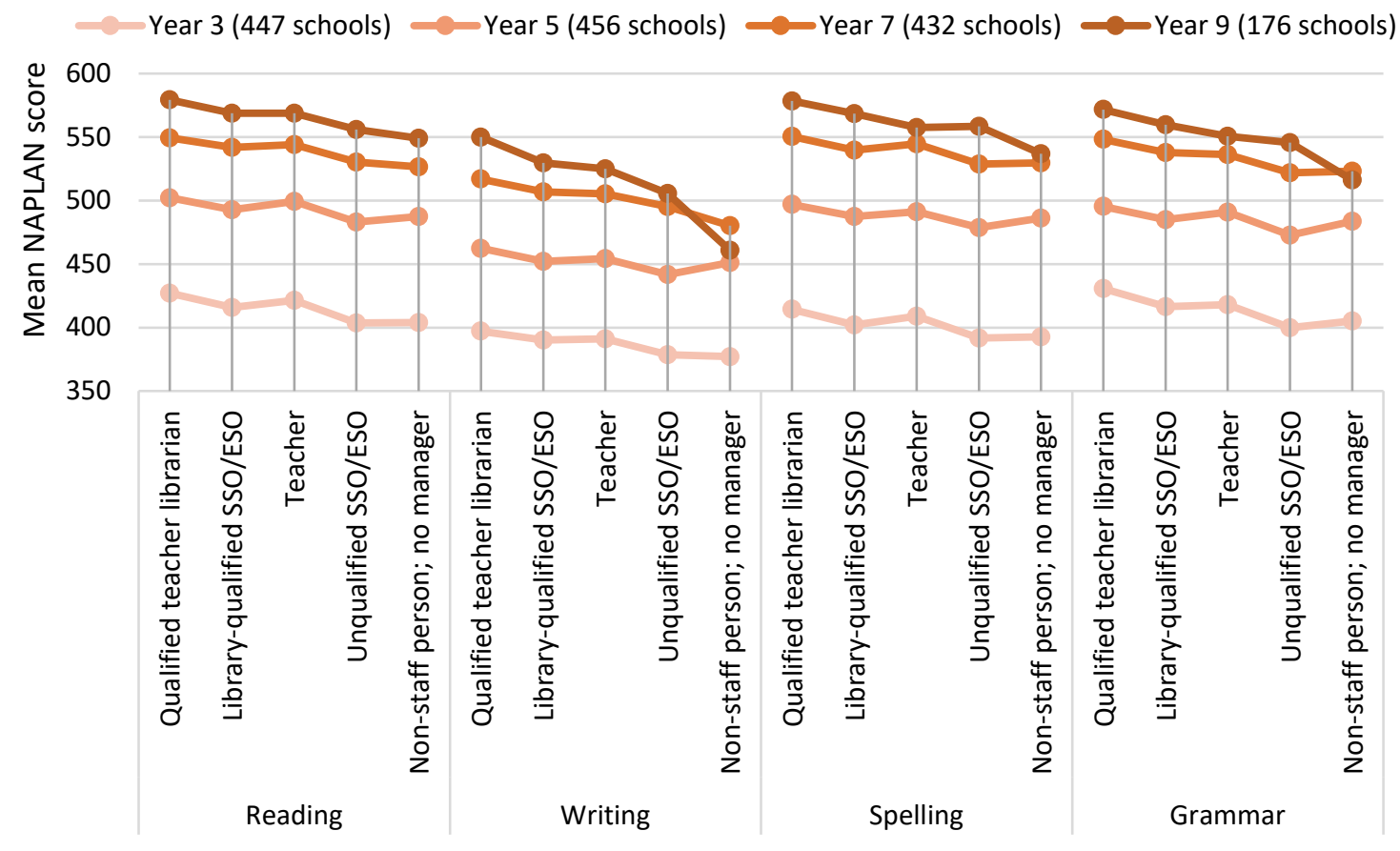

These findings point to a lack of qualified school library staff in South Australian schools. Strategies to raise the qualifications of those managing and working in school libraries include to actively recruit qualified teacher librarians to South Australian schools, support teachers managing school libraries to gain librarianship qualifications, and increase the number of libraryqualified support staff by sponsoring unqualified SSO/ESO working in libraries to gain a nationally recognised library training, available through TAFESA and other Registered Training Organisations.

\section{Levels of staffing}

While staffing the library with qualified people is important, having a sufficient number of staff to run the library and information resources is also important. Despite understanding the need for qualified staff in school libraries, a comparison of data from the annual Softlink school library surveys for the past few years show that $21 \%$ of schools reported a decrease in library staffing in 2016 (Softlink, 2017). In the more recent Softlink survey (2019), some respondents indicated that they did not have enough qualified staff in their library to support learning outcomes, particularly in the areas of digital literacy and research. Schools faced with this problem resort to a range of solutions. Although school libraries mainly focus on direct support for teachers' and students' needs than on the library and its particular practices, there are still significant technical tasks involved in managing a collection of learning resources (IFLA, 2015). In the Softlink 2017 survey, respondents indicated that they would like more staffing to support them in performing administrative functions, including catalogue and resource management, which would allow teacher librarians more time to engage with students, teach, and support curriculum objectives (Softlink, 2018). 
Considering the person managing the library, the census asked what fraction of time he or she was funded to manage the library. While $19 \%$ of those managing the library are funded full-time (1.0 FTE) in this role, another quarter (26\%) are funded between 0.6 and 0.9 FTE. Over half the school libraries (55\%) are managed on the equivalent of less than a half-time position.

To gain a deeper understanding of school library staffing, respondents were also asked how their school library was staffed (either funded or voluntary). While six categories of personnel that might work in the library were listed in the census, we focus here on the main library-qualified and unqualified staff to consider the different total FTE levels according to school type and school size. Figure 14 indicates that library-qualified SSO/ESOs in charge of a library are more likely to hold a fulltime role compared to a qualified teacher librarian. Unqualified SSO/ESO managers are, on average, employed for the same FTE as qualified teacher librarians.

Figure 14. Comparison of FTE staffing levels by school type and size against AEU SA staffing policy

\begin{tabular}{|c|c|c|c|c|c|c|c|c|c|c|c|c|c|c|c|c|}
\hline & & \multicolumn{4}{|c|}{ School Type \% } & \multicolumn{4}{|c|}{ Manager FTE } & \multicolumn{6}{|c|}{ FTE Staffing Levels } \\
\hline & & & 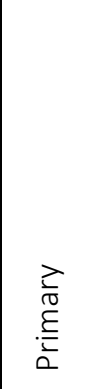 & 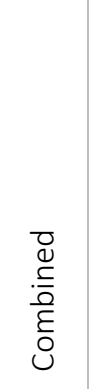 & $\begin{array}{l}\frac{Z}{0} \\
\frac{0}{0} \\
0 \\
0 \\
\mathbb{U} \\
\sim\end{array}$ & 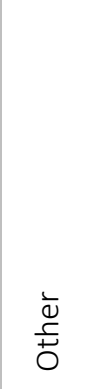 & 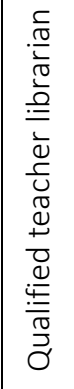 & 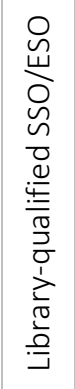 & 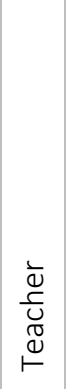 & 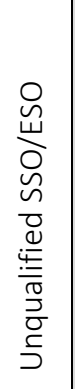 & 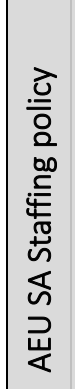 & 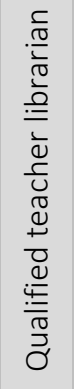 & 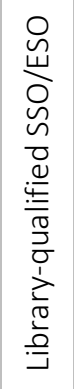 & 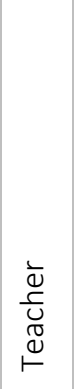 & 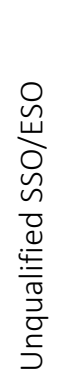 & 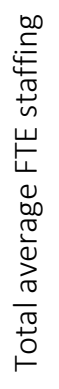 \\
\hline & & $n$ & 466 & 151 & 86 & 25 & 129 & 111 & 61 & 193 & & 165 & 222 & 127 & 398 & 623 \\
\hline \multirow{8}{*}{ 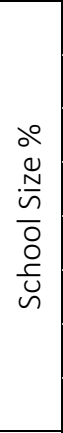 } & Below 200 & 279 & $27 \%$ & $6.3 \%$ & $1.8 \%$ & $3.0 \%$ & 0.3 & 0.4 & 0.2 & 0.3 & 0.3 & 0.6 & 0.7 & 0.7 & 0.5 & 0.6 \\
\hline & 200-399 & 199 & $22 \%$ & $4.3 \%$ & $1.4 \%$ & $0.1 \%$ & 0.6 & 0.7 & 0.5 & 0.6 & 0.7 & 0.7 & 1.1 & 0.8 & 0.6 & 1.1 \\
\hline & $400-599$ & | 114 & $10 \%$ & $2.3 \%$ & $2.7 \%$ & $0.1 \%$ & 0.7 & 0.8 & 0.5 & 0.7 & 1.2 & 0.9 & 1.1 & 0.7 & 1.1 & 1.6 \\
\hline & $600-799$ & 67 & $4.1 \%$ & $3.4 \%$ & $1.6 \%$ & - & 0.8 & 0.9 & 0.6 & 0.9 & 1.8 & 1.0 & 0.9 & 1.0 & 1.0 & 2.0 \\
\hline & $800-999$ & 31 & $0.7 \%$ & $1.4 \%$ & $2.1 \%$ & $0.1 \%$ & 0.9 & 1.0 & 0.8 & 0.9 & 2.3 & 1.1 & 1.4 & 1.2 & 1.3 & 3.0 \\
\hline & 1000-1199 & $\mid 15$ & - & $1.1 \%$ & $1.0 \%$ & - & 0.7 & 1.0 & - & - & 2.5 & 1.2 & 1.5 & 0.7 & 1.8 & 3.2 \\
\hline & 1200-1399 & | 14 & - & $1.4 \%$ & $0.5 \%$ & - & 0.9 & 1.0 & - & - & 3.0 & 1.3 & 1.4 & 0.4 & 1.2 & 2.7 \\
\hline & 1400 or more & 9 & - & $0.5 \%$ & $0.7 \%$ & - & 1.0 & - & - & - & 3.7 & 0.6 & 1.3 & 0.7 & 1.6 & 2.5 \\
\hline \multirow{4}{*}{ 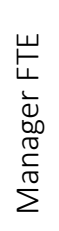 } & Qualified teacher librarian & 129 & 0.6 & 0.8 & 0.7 & 0.6 & & & & & & & & & & \\
\hline & Library-qualified SSO/ESO & $\mid 111$ & 0.6 & 0.8 & 0.9 & 0.8 & & & & & & & & & & \\
\hline & Teacher & 61 & 0.4 & 0.6 & 0.5 & - & & & & & & & & & & \\
\hline & Unqualified SSO/ESO & 193 & 0.4 & 0.7 & 0.8 & 0.4 & & & & & & & & & & \\
\hline \multirow{6}{*}{ 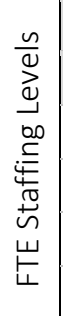 } & AEU SA Staffing policy & & 0.7 & 1.2 & 1.6 & 0.3 & & & & & & & & & & \\
\hline & Qualified teacher librarian & 165 & 0.7 & 1.1 & 1.1 & 0.9 & & & & & & & & & & \\
\hline & Library-qualified SSO/ESO & | 222 & 0.8 & 1.2 & 1.4 & 0.7 & & & & & & & & & & \\
\hline & Teacher & 127 & 0.6 & 1.0 & 0.7 & 0.3 & & & & & & & & & & \\
\hline & Unqualified SSO/ESO & | 398 & 0.6 & 1.1 & 1.3 & 0.6 & & & & & & & & & & \\
\hline & Total average FTE staffing & 623 & 0.9 & 2.2 & 1.9 & 0.5 & & & & & & & & & & \\
\hline
\end{tabular}


Figure 15. Average number of staff by school size

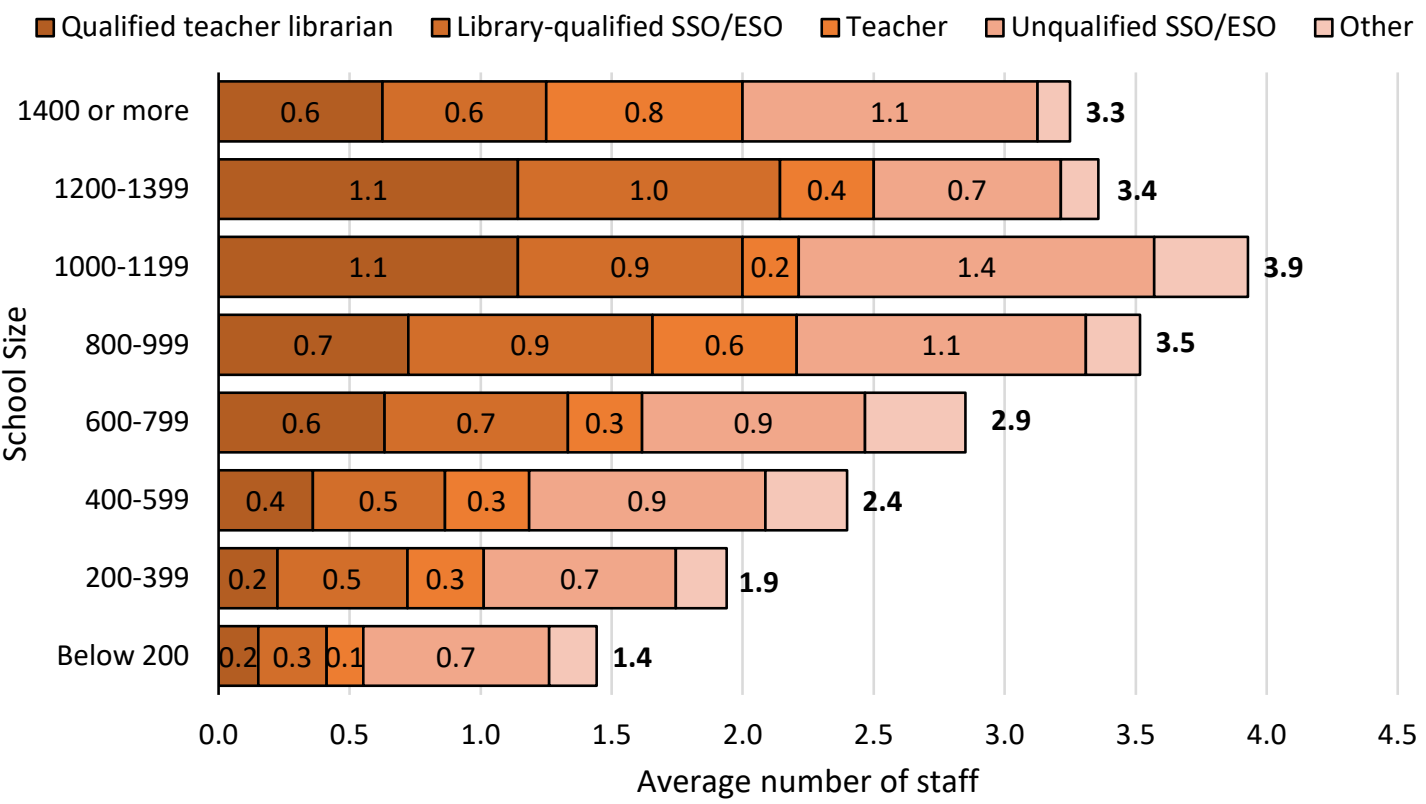

For $55 \%$ of schools, SSO/ESOs with no formal library qualifications are the most common member of the library staff. Around a quarter of school libraries have one Library-qualified SSO/ESO, with a further $5 \%$ having more than one staff member with this qualification.

Figure 16 Qualified teacher librarian allocation by school size compared to AEU SA 2013 policy

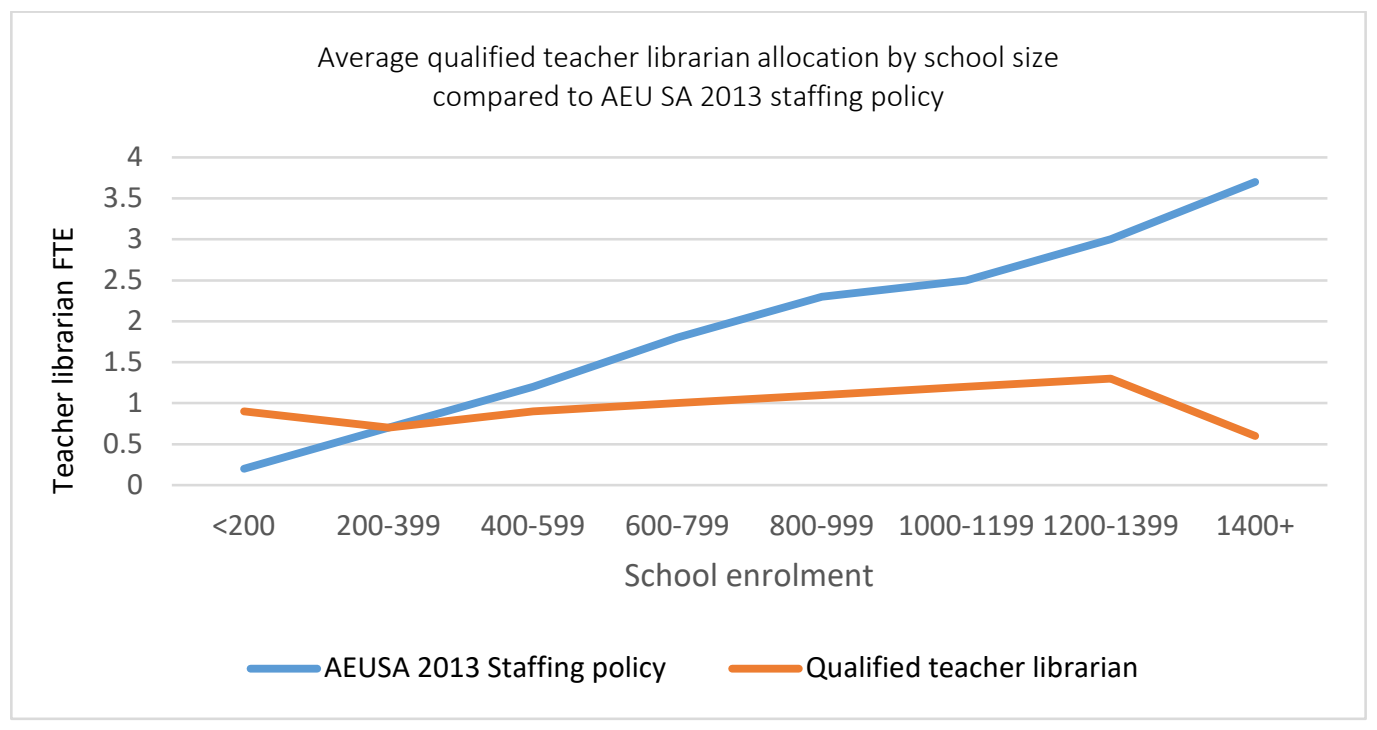

Figure 14 also presents for comparison, the FTE staffing levels of qualified teacher librarians recommended by the AEU SA (2013), against the total FTE staffing levels schools reported for each staff type. Figure 16 extracts the data for teacher librarians to show the comparison of qualified teacher librarians in South Australian schools compared to the AEU SA staffing policy. For example, while the AEU SA staffing policy recommends that a large school of between 10001200 students should have 2.5 FTE qualified teacher librarians on staff, an average of 1.2 FTE qualified teacher librarians are reported in these schools. 
When interpreting and comparing the average FTE results in Figure 14, it should be noted that respondents found this survey question challenging to answer and inaccuracy in reporting is possible. Approximations have also been introduced in the conversion of the categories of FTE range given in the AEU SA tables (2013) to an FTE value for use in Figures 14 and 16 to report an average FTE.

The results suggest that while smaller primary schools may be adequately staffed with a qualified teacher librarian, moderate to larger sized combined K-12 schools and secondary schools may be under-staffed according to AEU SA policy recommendations. The fact that large schools with more than 1200 students currently employ significantly less library staff per student than other schools, raises questions about the quality of library service and resource management in these large schools. Given these schools receive similar per student funding as schools in the 800-1200 size range, parents and the community would be entitled to question why students attending these schools are less well-resourced, and what the funds that others school allocate to library services is being spent on in these larger schools.

\section{Staff in school libraries tend to work in isolation}

Figure 17 presents the total number of staff on school library teams, regardless of being parttime or full-time (0.1-1.0 FTE inclusive). It suggests that $10 \%$ of schools are unstaffed and that a third of schools (34\%) only have one library staff person. Another quarter of schools (28\%) have two on the team. At the other extreme, four schools in South Australia have on staff 10 personnel of varying levels of qualification and FTE status.

Figure 17. Number of staff in library teams, including part-time roles

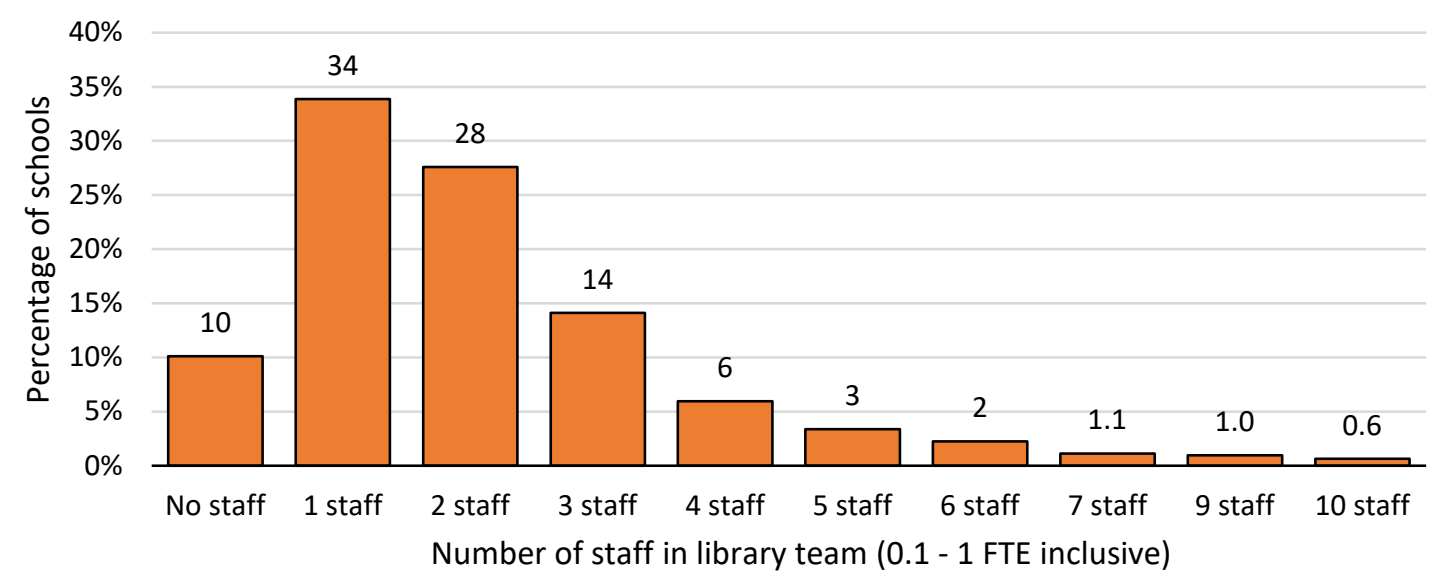

The census results suggest that the majority of library staff work in isolation and do not have the opportunity to work with others in a similar role or background to them.

The number and type of staff comprising the school library team was also considered relative to school size. In general, the larger the school, the greater the number of staff there are on teams. Figure 17 presents the results, which show that schools with 1000-1200 students have, on average, four members on staff. Small schools with 200-300 students generally have two people on the library team. It is likely that the drop in staffing for the larger schools may have be an error related to the challenges in accurately answering the question. 


\section{FACILITIES, COLLECTIONS AND ACCESS}

The advent of digital content and the technologies used to access this content have brought significant changes to school library practices in the past two decades. The impact of this change is seen most clearly in both the nature of library collections, and in the way the school community accesses these collections. There are ongoing challenges in managing digital collections to ensure effective and equitable access.

The best school libraries have a combination of physical and digital resources in their collection and, consequently, there are a range of physical and digital tasks involved in providing highquality library services. Care and maintenance of technology and the physical collection are vitally important, but can sometimes be misunderstood to be the only things required in a library. A school library with only a teacher librarian will hobble what the teacher librarian can do because s/he will have to manage the physical collection as a necessary, practical priority. In contrast, a school library run by a school assistant will likely be tidy; however, fewer digital resources will be in the collection, no information or digital literacy skills will be taught and no collaborative teaching and planning will happen. To reach their full potential, school libraries must have a team of qualified staff (Godfree \& Neilson, 2018, p. 34).

According to evidence collected from schools in the UK, the best libraries provide excellent collections and succeed to meet a wide range of demands from teachers and students (Ofsted, 2006; Clark \& Teravainen, 2017).

Alongside the integration of digital learning resources, many schools have reviewed their use of physical space. The availability of space influences the size of a library, and some schools may use classroom and common areas to display resource materials (Ofsted, 2006). Space availability influences the type of access, and impacts decisions around whether to operate a full-service library or to move to other forms of access such as, a school-community, classroom, online, or teacher reference library.

Another important factor is the frequency of access. Research shows that most effective schools try to ensure longer opening hours to accommodate different readers' needs (Ofsted, 2006; Clark \& Teravainen, 2017). Moreover, there is a link between the staffing arrangements and the level of access, as students who attend schools with on-staff qualified teacher librarians have more equitable access to technologically advanced library facilities, databases and resources for longer times during the school day and outside normal school hours (Scholastic, 2016).

Findings from the Softlink's 2017 Australian and New Zealand School Library Survey into school library budgets, staffing, library services, and future trends suggest that when asked about whether cloud-based technologies will increase library accessibility, $77 \%$ of respondents indicated that this would have a moderate to high impact (Softlink, 2018). Respondents also suggested that they would like to provide $24 / 7$ access to the library and purchase more electronic resources including eBooks and subscription databases (Softlink, 2018). There has been a growing requirement for digital and online resources and that school-wide access and integration for engaging students in learning (Softlink, 2016, 2017, 2018) and school libraries are spending more and more to set-up for this transition to digital learning (Softlink, 2016; Scholastic, 2016; Clark \& Teravainen, 2017). The 2017 Softlink survey also identified that the establishment of an "engaging and welcoming space for learning and leisure" is considered by schools to be the most important 
service that school libraries hope to provide (Softlink, 2018, p. 16). Data from previous surveys show that Australian school libraries have recognised the growing trend towards online research and responded to the demand (Softlink, 2016). Rather than just focusing on e-resources, most contemporary school libraries are blending these newer approaches with traditional approaches, rather than abandoning physical resources entirely (Softlink, 2016).

Figure 18 conceptualises the range of provisions that are available to schools and illustrates the relationship between the spaces and level of centralisation for different forms of libraries. According to the literature, the growing trend for many schools in Australia is to reconfigure their library spaces to embrace a model of integrated library services - where traditional library resources are combined with virtual resources.

Figure 18. The different forms of libraries space, collections and access

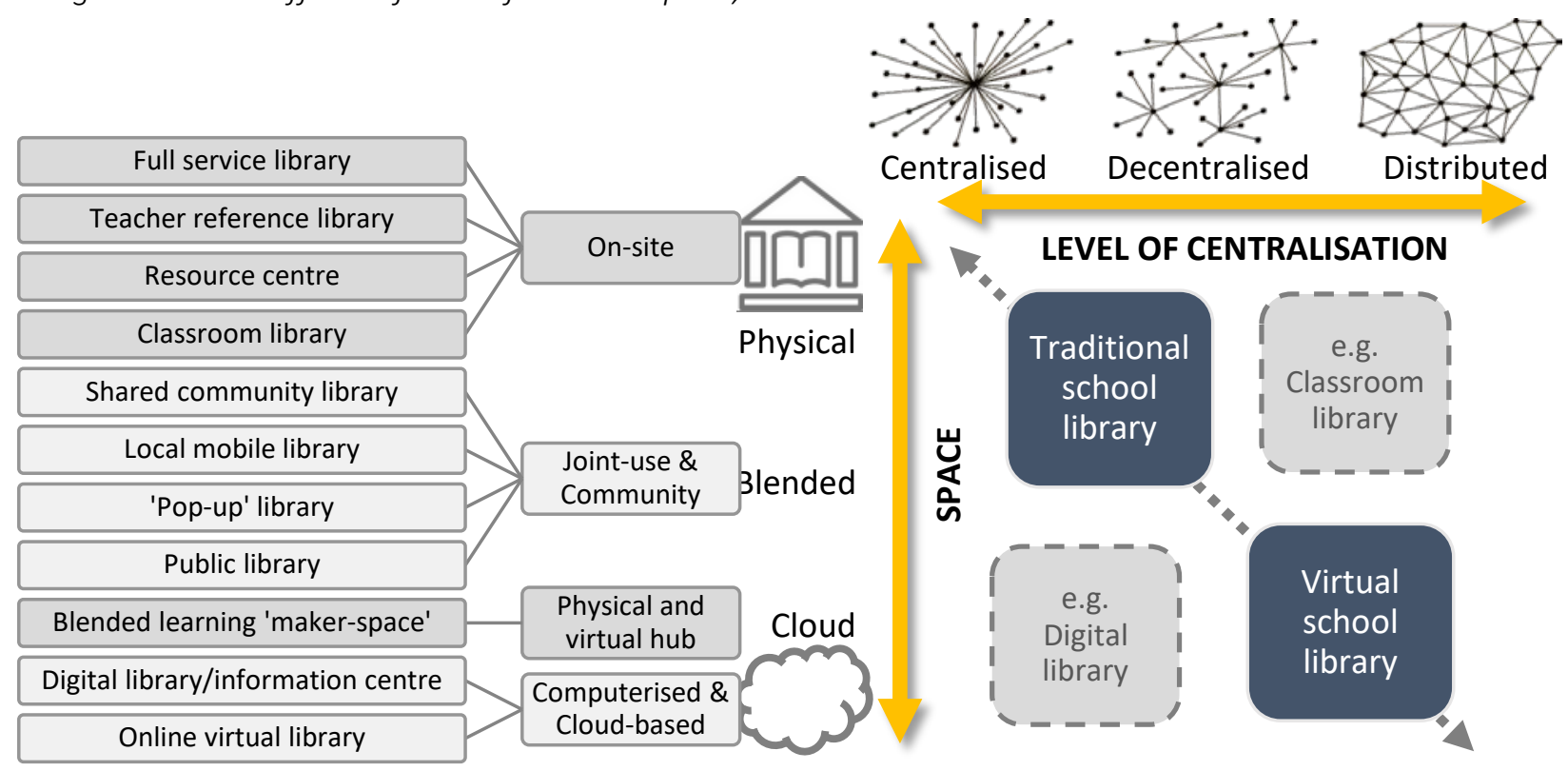

Decisions regarding the degree of centralisation and the access models range across a spectrum from purely physical to a fully virtual library. School seek a balance of formats and access models to suit their context. Even for a school whose attendance mode is fully virtual, such as Open Access College (including School of the Air), physical resources remain an integral part of their library service. Some libraries have installed technologies and materials in 'maker-spaces', where students create, produce and publish. The changing purpose of libraries, in addition to maintaining the traditional roles of promoting reading, developing information literacy and providing access to books and other resources, are now seen as fundamental to broader digital literacy, information provision and developing critical evaluation of information (Swain, 2015; Tait, Vo-Tran, Mercieca \& Reynolds, 2019). Lance and Kachel (2018) endorse this idea.

Students tend to thrive academically where library programs provide ready access to free and subscription-based online resources alongside more traditional collections of books, periodicals, and audio-visual resources (Lance \& Kachel, 2018, p. 18). 


\section{The types of libraries are diverse}

To get to the heart of the nature of school library services, without implying that a school had one, schools were asked more broadly in the census, what types of access to reading, research and curriculum resources staff and students had at their school. Many respondents chose a range of options, shown in Figure 19. While 35\% of schools indicate that they only have access to $a$ central library or resource centre, the majority of schools (86\%) have a central library or resource centre along with other ways to access reading, research and curriculum resources. Many of these also indicate they have a teacher reference library and/or multiple copy collections.

Figure 19. Percentage of schools according to type of library: Access to reading, research and curriculum resources $(n=728)$

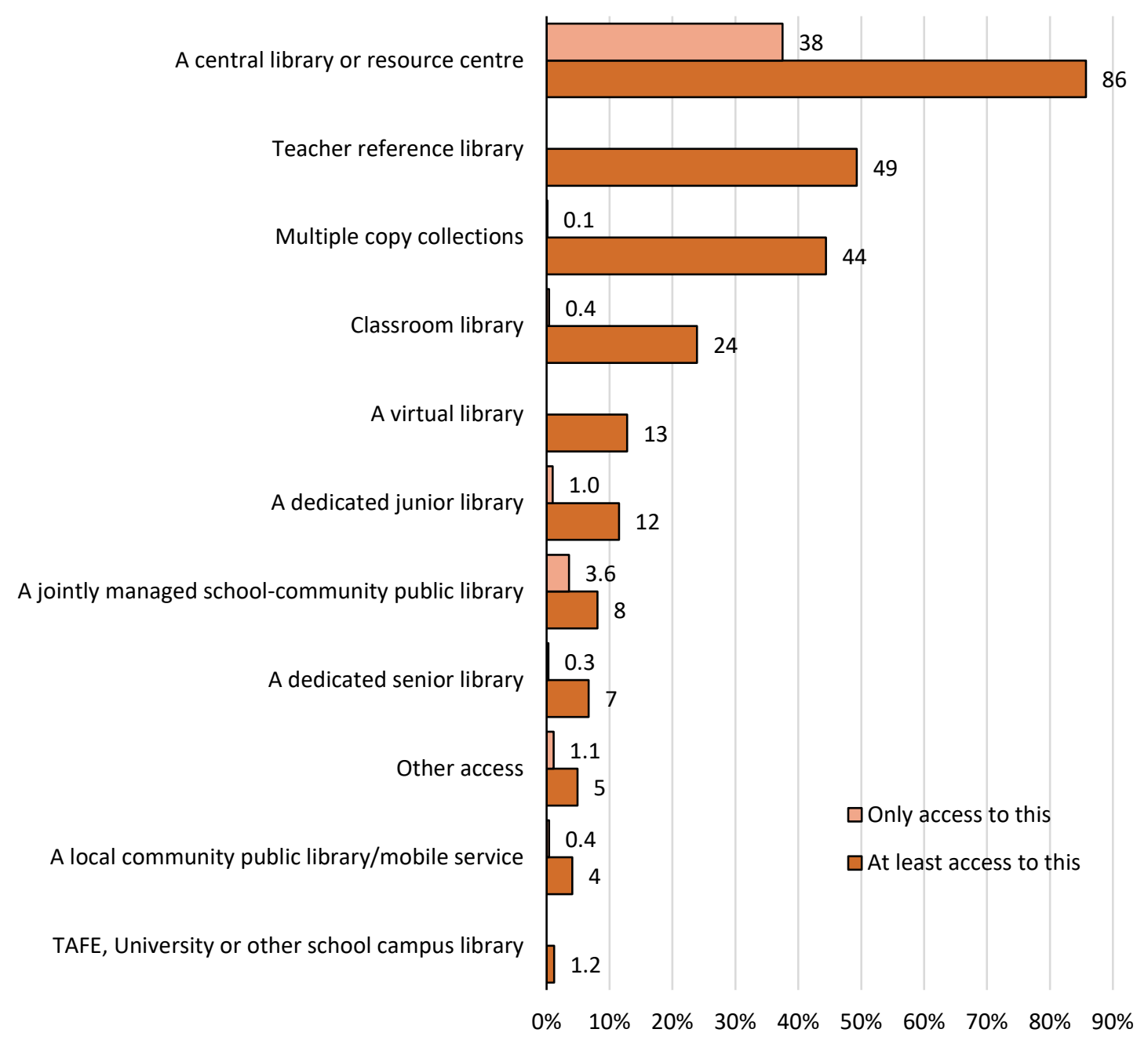

When asked to describe their school's library, Principals described this diverse range of models in more detail. A selection of the open-text responses is included in Table 2. 
Table 2 Principals description of their school's library

Our library has been designed as a hub of the school connecting classroom learning spaces. It has a flexible furniture structure which enables the space to be used according to the activities taking place.

Our library is used daily by both staff and students servicing over 600 people. Students have access to this space during break times and it is well used by all. Senior Secondary students also use this space as a quiet place to work.

Our school library was substantially changed through a STEM works redevelopment in SA. It offers a reduced physical collection, online library and ICT services. It is now called the Learning Hub and incorporates breakout rooms, tiered seating lecture space and other collaboration spaces.

Our Discovery Centre is located in the centre of our STEM facilities, one of 5 spaces within STEM. Access is gained through an online booking system where staff and students can access one or more of the spaces simultaneously depending on the type of learning they are doing and the resources they require.

Our Librarian teaches in our school one day a fortnight.

Our library is a hive of activity. Students are able to access the library before school for reading, activities, socialisation, keeping warm.

Our library is in a central location, in between our primary and secondary learning areas. Each primary class borrows regularly and has a fortnightly session discussing books with the librarian. There is a fortnightly Rockin' Readers session for playgroup, including tea/coffee for parents and the preschool visit weekly

Our library is open for borrowing two mornings per week before school.

No longer feasible to resource with teacher. SSO part time. Teachers still take groups of students to browse and borrow, use the space to do research activities, read with buddies and participate in special events. Student Leaders conduct lunchtime programs for students in the space and there is also a dedicated area for creative play.

Large space where the whole school can gather, highly resourced with fiction and nonfiction books, multimedia TV available for teaching purposes, the library is open during lunch times of students to access resources for enjoyment, relaxation and for their inquiry projects.

Just had a refurbishment and is an exciting place for teachers and students to learn. New shelving and spaces for relaxation, study, craft and library staff to work.

It is a struggle to staff our library with a qualified and/or experienced teacher librarian.

It is a new small library that we are in the process of establishing fully with the assistance of volunteers.

It has largely become redundant as students have laptops and collaborative learning spaces around the school. Re-designs have created more flexibility. We have one or two specialist programs running in annexes to the library and it does have books for loan. It is used after school as a learning support hub on one day. all student services will soon be located there (bi lingual, ICT help, Counsellors, sick room, etc)

Book Week and the Book Fairs are highlights for our school. Students have easy access to the library which is open during school hours daily.

Being a special school with a specialised program, most of our library resources are integrated into the classroom. We are a new school with limited resources and are currently in the process of setting up a new library space.

All resources are provided digitally and through learning areas. 
We have visits each month from the mobile library. Each classroom has a small library of books and we visit the local library.

We have a whole-school library with books to read and area for lessons to take place. We have an SSO working in the library on Mondays and Tuesdays. Every student takes library books home.

This joint use library is based on a secondary site and caters more for public use. In the years I have been here, classes do not come into the library for curriculum activities, library staff do not assist or lead 'library lessons' around research etc. and students are often made to feel unwelcome in the library space at break times.

The teacher Librarian also has the role for computational thinking and digital technologies.

The School Community library and provides for public access and school usage. Regular public library activities occur as well as class and teacher use during school days. School resources are also accessible and available across the One Card Network. All South Australian Public library e-subscriptions area also accessible.

The Resource Centre is staffed 0.6 by SSO2 and 0.2 teacher. Teaching space within library is shared by 0.2 teacher and a 0.4 STEM teacher. Library houses teacher resources as well as general borrowing collection. library also contains 16 desktop PCS

The library is staffed by two classroom support SSOs with 15 hours per week dedicated to library - mainly returns and borrowing plus ongoing culling of resources. Library very traditional model in layout and structures but SSOs do not have skills, knowledge or time to move forward. School plans to update layout in the future to make space more flexible and supportive of 21 st learning

Presented as a comfortable place that privileges books in a learning space. Engaging texts are read to children. Students read independently.

Overseen by a library Resource Manager, with a focus on developing a love of reading, and library as a community space, as well as managing and constantly improving library collection. Includes occasional 'pop-up' library spaces around the school in good weather.

\section{Library spaces}

The census results also indicate that half the schools (48\%) have dedicated space on-site for library activities and resources equivalent to three or more standard classrooms. How this relates to school context, is discussed in the next section. Figure 20 also shows that for $58 \%$ of schools, this space has not been recently encroached upon, while for a third of schools, their library has been encroached upon, temporarily (11\%) or permanently (22\%). 
Figure 20. Percentage of schools according to the amount of dedicated space the library has and if it has been encroached upon ( $n=700)$

$\square$ Not applicable (10\%) $\quad \square$ No (58\%) $\quad \square$ Yes, temporary (11\%) $\quad \square$ Yes, permanent (22\%)

Three or more classrooms

Two classrooms

One classroom

Less than one classroom

No dedicated space on campus

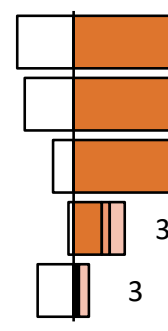

$0 \%$

\section{口Yes, temporary $(11 \%)$}

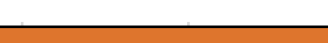

$10 \%$

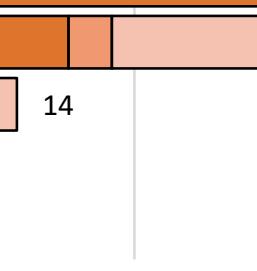

$20 \%$
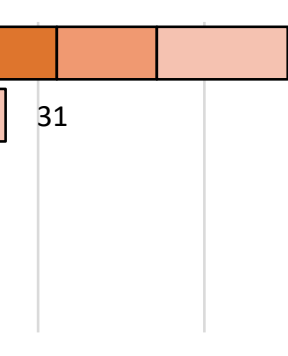

31

$30 \%$
48

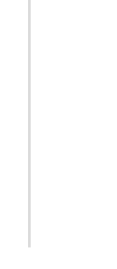

$40 \%$

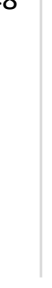

$50 \%$

When asked to describe the nature of the encroachment, those who thought it was a permanent change said it was for classroom break-out rooms, space for non-instructional time, for STEM or digital learning, or for some other use such as administration, preschool use, or as a uniform shop. Temporary encroachment was also likely to be for classroom break-out rooms or space for noninstructional time, but most often was described as a change due to construction renovation work. Table 3 presents a selection of respondents' comments arranged by the emerging themes, of the main reasons given for the loss of library space, seen as permanent for some schools and temporary for others. An indication of the frequency of comments under each theme is also provided.

Table 3. Reasons given for the temporary or permanent encroachment on library space

\begin{tabular}{|c|c|c|}
\hline Theme & Temporary encroachment & Permanent encroachment \\
\hline $\begin{array}{l}\text { STEM; Digital } \\
\text { Learning; } \\
\text { Makerspace } \\
(24 \%)\end{array}$ & $\begin{array}{l}\text { Computer room is now in the Library } \\
\text { Now holds computers for } 30 \text { students and area } \\
\text { Senior Science classes without screen/projector } \\
\text { access } \\
\text { Shared computer area } \\
\text { Small rooms used for outside agencies and } \\
\text { Makerspace and Media filming (green screen } \\
\text { STEM Classes and ICT office } \\
\text { Stem has taken over } 1 \text { area } \\
\text { Used for Lego League activities } \\
\text { We established a STEM specialist area and plans to } \\
\text { build a contemporary library as part of school } \\
\text { refurbishment in } 2021 \\
\text { We have moved because the school will have major } \\
\text { renovations/building works in } 2019 / 2020 \text { - the new } \\
\text { area will be an 'innovation centre' which will house } \\
\text { the library collection and also the STEM activities } \\
\text { We use the space for our junior primary computing } \\
\text { lessons on laptops. } \\
\text { Whilst we were having our STEM building built we } \\
\text { had to move a class in the library temporarily }\end{array}$ & $\begin{array}{l}\text { A room formerly available for classes and exams is } \\
\text { now used for the school server stack, which puts an } \\
\text { unpleasant electrical field so the room is no longer } \\
\text { used by people. } \\
\text { Change in building design due to STEM building } \\
\text { works } \\
\text { Classroom also used for STEM \& Digital technologies } \\
\text { Computer room added } \\
\text { The computers have now been moved into the } \\
\text { Library, due to our student numbers increasing and } \\
\text { the need for the extra classroom } \\
\text { One classroom equivalent space taken for FLO } \\
\text { learning centre } \\
\text { Within the resource centre there is a designated } \\
\text { computer area which we also housed part of our } \\
\text { collection. This area has been repurposed and we } \\
\text { have had to move our collection back into the } \\
\text { remaining space of approx. } 2 \text { classrooms. In the past } \\
\text { we had available } 3+ \\
\text { Digital Technology and Class Room Space with Smart } \\
\text { Board are also within the Resource Centre Space } \\
\text { ICT services have taken up residence } \\
\text { Library became STEM Centre. }\end{array}$ \\
\hline
\end{tabular}




\begin{tabular}{|c|c|c|}
\hline Theme & nment & hment \\
\hline (32\%) & $\begin{array}{l}\text { A special class is using some of the space after } \\
\text { being recently relocated } \\
\text { Currently used for making performing art props, } \\
\text { training, choir and delivering literacy and numeracy } \\
\text { support programs } \\
\text { Japanese lessons } \\
\text { Junior Primary HASS is taught in the library for this } \\
\text { year } \\
\text { Learning support and outsourced specialists (i.e. } \\
\text { speech pathologists use spaces in the library as } \\
\text { recent renovations have meant their spaces have } \\
\text { lost functionality } \\
\text { Learning Support has taken a classroom area worth } \\
\text { of space } \\
\text { Senior School study room } \\
\text { To allow for an EALD teaching space } \\
\text { Unknown if temporary or permanent - NIT is taught } \\
\text { in this space but this is not necessarily a negative } \\
\text { thing. } \\
\text { Use for German classes } 1 \text { day per week } \\
\text { Used for music lessons and small group work } \\
\text { throughout the day } \\
\text { Used for OAC lessons } \\
\text { Year } 5,6,7 \text { classes use the library's senior fiction } \\
\text { area as a breakout area for class projects on a daily } \\
\text { basis for } 2 \text { or } 3 \text { lessons a day. }\end{array}$ & $\begin{array}{l}\text { All resources from the room dedicated to support } \\
\text { staff to rub small group reading which included } \\
\text { multiple copies of reading program books and } \\
\text { language/literacy-based resources were moved into } \\
\text { the library to accommodate an alternative use for the } \\
\text { room. } \\
\text { Also used for space for OSHC - limited spaces in } \\
\text { school } \\
\text { Book room has been added to our space } \\
\text { Career Hub } \\
\text { Choir practice, staff meetings, Training and } \\
\text { development } \\
\text { Currently the library has been moved to Meeting } \\
\text { Room, restricting use of this space, due to student } \\
\text { behaviours where accessible books were ripped, torn } \\
\text { and thrown during repetitive meltdowns. } \\
\text { Emphasis has moved to more a Student Hub than a } \\
\text { Library. } \\
\text { Green screen room. Textbook room. Uniform Room. } \\
\text { Administration Room. } \\
\text { Learner Wellbeing and Engagement Hub } \\
\text { More open space for visitors; sitting area for students } \\
\text { Music, Assemblies, performance, drama } \\
\text { One third will be removed to accommodate children } \\
\text { with special needs } \\
\text { Resource area was cleared for a Wellbeing } \\
\text { counselling room }\end{array}$ \\
\hline $\begin{array}{l}\text { Additional } \\
\text { classroom } \\
\text { space needed } \\
(21 \%)\end{array}$ & $\begin{array}{l}1 \text { class moved in due to renovations in a classroom } \\
\text { A class is based in one of the rooms } \\
\text { A classroom was housed in the library for a year. } \\
\text { classroom size space allocated to tutors and } \\
\text { therapist learning } \\
\text { Classroom use } \\
\text { Classroom using one class size area with the ability } \\
\text { to restore this space to library if the enrolments } \\
\text { drop and a classroom becomes available } \\
\text { Extra classroom for two years } \\
\text { Increase in school enrolments } \\
\text { increased student enrolments meant we had to add } \\
\text { a classroom, so Spanish now shares the library } \\
\text { space } \\
\text { It is a classroom while another is being built, (It is a } \\
\text { classroom while another is being built } \\
\text { One of our rooms is now a permanent Radio Station } \\
\text { and our Teacher Resources Area is being used a } \\
\text { temporary classroom }\end{array}$ & $\begin{array}{l}\text { break out work space for adjacent classroom } \\
\text { Class space needed } \\
\text { Classroom and staff meetings } \\
\text { Classroom sized area now dedicated Music Room } \\
\text { classroom, music area, special literacy area } \\
\text { Due to increased enrolments } \\
\text { It was moved from a dedicated library space to a } \\
\text { classroom } \\
\text { Library was re-purposed for classroom and special ed } \\
\text { space. Library moved into a centralised space about } \\
\text { half the size } \\
\text { Main library space repurposed for classroom use due } \\
\text { to increased enrolments. Library moved to alternative } \\
\text { space. } \\
\text { moved from previous space to smaller classroom to } \\
\text { make way for duel classrooms } \\
\text { moved to a smaller location to accommodate } \\
\text { students in the previous larger space }\end{array}$ \\
\hline $\begin{array}{l}\text { Building } \\
\text { construct } \\
\text { or renova }\end{array}$ & $\begin{array}{l}\text { Due to building works, classes have been } \\
\text { timetabled to the Library space for } 12 \text { lessons a } \\
\text { week. }\end{array}$ & $\begin{array}{l}\text { Refurbishment } \\
\text { We have an extra class this year, so the library was } \\
\text { halved to accommodate this, it will probably stay that }\end{array}$ \\
\hline
\end{tabular}




\begin{tabular}{|c|c|c|}
\hline Theme & Temporary encroachment & Permanent encroachment \\
\hline (9\%) & $\begin{array}{l}\text { Has been used as classrooms during building works. } \\
\text { Currently back to original use as a library. } \\
\text { Has been used for } 2 \text { classrooms while a building } \\
\text { program is in progress } \\
\text { Learning support and Aboriginal Education are now } \\
\text { housed in back of library until new building is } \\
\text { completed } \\
\text { New Building for Junior School in development } \\
\text { New building space for } 2020 \text { includes expansion } \\
\text { space for Learning Hub } \\
\text { Re fit of current Yr } 7-12 \text { space to make way for new } \\
\text { Middle School Teaching and Learning Building. } \\
\text { New Resource Centre part of Master Plan for future } \\
\text { build }\end{array}$ & $\begin{array}{l}\text { way for the time being while we embark on a building } \\
\text { program. }\end{array}$ \\
\hline $\begin{array}{l}\text { Staff needs } \\
(9 \%)\end{array}$ & $\begin{array}{l}\text { People keep putting stuff they don't need into the } \\
\text { library porch. I am then left to clean up or work out } \\
\text { where to put these things. } \\
\text { Space used for teacher intervention programs } \\
\text { To add extra teacher desks } \\
\text { Two staff offices }\end{array}$ & $\begin{array}{l}\text { Meeting room office taken out of space } \\
\text { NIT lessons take place in there } \\
\text { Office space } \\
\text { Some of the area has been changed to staff offices } \\
\text { Teacher resource area cut significantly, also library } \\
\text { office space being used for storage of broken/out-of- } \\
\text { date computer equipment. } \\
\text { Teacher Resources room given to students to relax in. } \\
\text { Yes, to make more office space } \\
\text { Yr } 12 \text { study room and senior staff office }\end{array}$ \\
\hline $\begin{array}{l}\text { Downsized } \\
(5 \%)\end{array}$ & Limited space in current location & $\begin{array}{l}2 \text { years ago we downsized from a three or more } \\
\text { standard classroom size to a } 1 \text { standard classroom } \\
\text { size. } \\
\text { Has been moved within the school permanently to a } \\
\text { smaller location. Has happened twice in the last } 6 \\
\text { years } \\
\text { Junior \& Middle/Senior separate libraries were } \\
\text { combined \& condensed into a much smaller space } \\
\text { Relocated } \\
\text { School merger to one campus } R \text { - } 12 \text { JS Library much } \\
\text { smaller } \\
\text { We now share the library space with the school next } \\
\text { door. We have half the library space each. }\end{array}$ \\
\hline
\end{tabular}

\section{Profile of a 'typical' school library emerges}

Earlier, we considered the range of provisions that are available to schools, and illustrated in Figure 18 the possible relationship between the space and level of centralisation for different forms of libraries. The results from the census clarify the picture for South Australia. Rather than the degree of centralisation being a main theme, the spectrum of differing provision styles available ranged from a purely physical space on-site, through to a physical and virtual offering, through to nothing on-site at all. From this analysis of space (see Figure 18) and library type (see Figure 19), eight clear profiles of library emerge. Accordingly, all schools are categorised into one 
of these eight forms of library provision, based on the types of access to reading, research and curriculum resources staff and students have at their school and the amount of dedicated space on-site for library activities and resources. Figure 21 presents the profiles of library provision.

The census results report that, overall, $38 \%$ of all schools in South Australia only have access to a central physical library on-site. It suggests that schools with only a central library, tended to be a primary school with less than 800 students. In other words, $42 \%$ of primary schools in South Australia service their community through a central library. A further $40 \%$ of all schools have a physical library on-site, which includes central and decentralised resources (such as in classrooms). These schools tended to be low SES, remote, primary schools. This suggests that the 'typical' profile of around three-quarters of South Australian schools still follows a traditional format that does not substantively use online resources.

The next level of category reflects hybrid schools with both physical on-site resources and virtual access to library resources (13\%). There were no schools reporting only virtual access to library resources. These schools tend to be large secondary schools in high SES metropolitan areas. In other words, $67 \%$ of large schools catering for over 1400 students and $30 \%$ of secondary schools, offer this mode of library service provision.

Figure 21. Categories of 'typical' access to reading, research and curriculum resources by school context $(n=728)$

\begin{tabular}{|c|c|c|c|c|c|c|c|c|c|c|}
\hline & & & & ysical on-site sc & nool libra & & Mo & Jointly & Access to & \\
\hline & & $\begin{array}{l}\text { or } \\
\text { evidence } \\
\text { of library }\end{array}$ & $\begin{array}{c}\text { Central } \\
\text { library } \\
\text { only }\end{array}$ & $\begin{array}{c}\text { Central \& } \\
\text { decentralised }\end{array}$ & $\begin{array}{l}\text { With } \\
\text { virtual } \\
\text { access }\end{array}$ & $\begin{array}{l}\text { With } \\
\text { mobile } \\
\text { access }\end{array}$ & $\begin{array}{l}\text { library } \\
\text { access } \\
\text { only }\end{array}$ & $\begin{array}{l}\text { managed } \\
\text { school- } \\
\text { community } \\
\text { library only }\end{array}$ & $\begin{array}{l}\text { other } \\
\text { off-site } \\
\text { library } \\
\text { only }\end{array}$ & $\begin{array}{c}\text { Average } \\
\text { 'classroom' } \\
\text { space }\end{array}$ \\
\hline $\begin{array}{l}\text { Percentage } \\
\text { are relati } \\
\end{array}$ & $\begin{array}{l}\text { ereported below } \\
\text { ve to category }\end{array}$ & $2.7 \%$ & $37.5 \%$ & $39.8 \%$ & $12.6 \%$ & $2.7 \%$ & $0.4 \%$ & $3.6 \%$ & $0.5 \%$ & \\
\hline & Primary & $0.6 \%$ & $41.8 \%$ & $45.5 \%$ & $6.4 \%$ & $3.6 \%$ & $0.2 \%$ & $1.5 \%$ & $0.2 \%$ & 2.2 \\
\hline School & Combined & $3.3 \%$ & $28.5 \%$ & $34.4 \%$ & $22.5 \%$ & $0.7 \%$ & $0.7 \%$ & $9.9 \%$ & & 2.7 \\
\hline type & Secondary & $7.0 \%$ & $31.4 \%$ & $24.4 \%$ & $30.2 \%$ & & & $3.5 \%$ & $3.5 \%$ & 2.8 \\
\hline & Other/Special & $24.0 \%$ & $32.0 \%$ & $20.0 \%$ & $8.0 \%$ & $8.0 \%$ & $4.0 \%$ & $4.0 \%$ & & 1.0 \\
\hline & Below 200 & $5.4 \%$ & $39.4 \%$ & $36.9 \%$ & $4.7 \%$ & $5.7 \%$ & $1.1 \%$ & $6.1 \%$ & $0.7 \%$ & 1.7 \\
\hline & 200-399 & & $38.7 \%$ & $49.2 \%$ & $5.5 \%$ & $2.0 \%$ & & $3.5 \%$ & $1.0 \%$ & 2.4 \\
\hline School & 400-599 & $1.8 \%$ & $36.8 \%$ & $38.6 \%$ & $21.9 \%$ & & & $0.9 \%$ & & 2.6 \\
\hline size & $600-799$ & $3.0 \%$ & $41.8 \%$ & $38.8 \%$ & $16.4 \%$ & & & & & 3.2 \\
\hline No. of & 800-999 & & $29.0 \%$ & $35.5 \%$ & $32.3 \%$ & & & $3.2 \%$ & & 3.3 \\
\hline ents & 1000-1199 & & $33.3 \%$ & $13.3 \%$ & $53.3 \%$ & & & & & 3.6 \\
\hline & 1200-1399 & & $7.1 \%$ & $35.7 \%$ & $57.1 \%$ & & & & & 3.8 \\
\hline & $1400+$ & $11.1 \%$ & $11.1 \%$ & $11.1 \%$ & $66.7 \%$ & & & & & 3.5 \\
\hline & Metro & $3.8 \%$ & $35.8 \%$ & $40.0 \%$ & $16.6 \%$ & $1.7 \%$ & $0.5 \%$ & $0.7 \%$ & $0.9 \%$ & 2.5 \\
\hline Location & Regional & $1.2 \%$ & $40.3 \%$ & $37.5 \%$ & $7.9 \%$ & $5.1 \%$ & $0.4 \%$ & $7.5 \%$ & & 2.1 \\
\hline & Remote & $1.9 \%$ & $37.7 \%$ & $49.1 \%$ & $3.8 \%$ & & & $7.5 \%$ & & 2.1 \\
\hline & Low $<950$ & $2.6 \%$ & $39.6 \%$ & $44.8 \%$ & $5.8 \%$ & $2.6 \%$ & $0.6 \%$ & $3.2 \%$ & $0.6 \%$ & 2.2 \\
\hline SES Med & ium 950-1050 & $2.8 \%$ & $39.5 \%$ & $37.9 \%$ & $11.5 \%$ & $3.1 \%$ & & $5.1 \%$ & & 2.3 \\
\hline & High > 1050 & $2.7 \%$ & $31.5 \%$ & $39.7 \%$ & $20.7 \%$ & $2.2 \%$ & $1.1 \%$ & $0.5 \%$ & $1.6 \%$ & 2.5 \\
\hline
\end{tabular}


Figure 19 and Figure 21 also show that 4\% of schools indicate access only to a jointly managed school-community library that might be located near, adjacent to, or within the school but with access to the public outside of school hours. Schools with only a jointly managed schoolcommunity library tend to be a combined K-12 school with less than 200 students, in a regional or remote location.

A small number of schools have mobile and school library access (3\%) or only access to a mobile library (0.4\%). These schools are more likely than other schools to say that any physical space has been permanently encroached upon and repurposed. These schools are more likely to be small regional special schools.

About 3\% of schools are without a library, or don't give any information about a library resource. This matches closely to the information found via the school website review and tends to be metropolitan special schools.

The far right column of Figure 21 takes the results presented in Figure 20 to investigate the average amount of space dedicated to school library activities and resources, in terms of equivalent 'classroom' size. There is a clear relationship with school size - bigger schools have, on average, more dedicated space - ranging from almost two classrooms' worth up to almost four classrooms' worth. High SES schools, secondary schools and metropolitan schools tend to have more dedicated space than Low SES schools, special schools and school located in nonmetropolitan regions.

Figure 22 presents the emergent model of school libraries in South Australia. It shows that most schools (94\%) have a centralised library space, and of these $40 \%$ also have decentralised resource with $13 \%$ also having access to virtual online resources.

Figure 22. Profile of South Australia's school library and information services

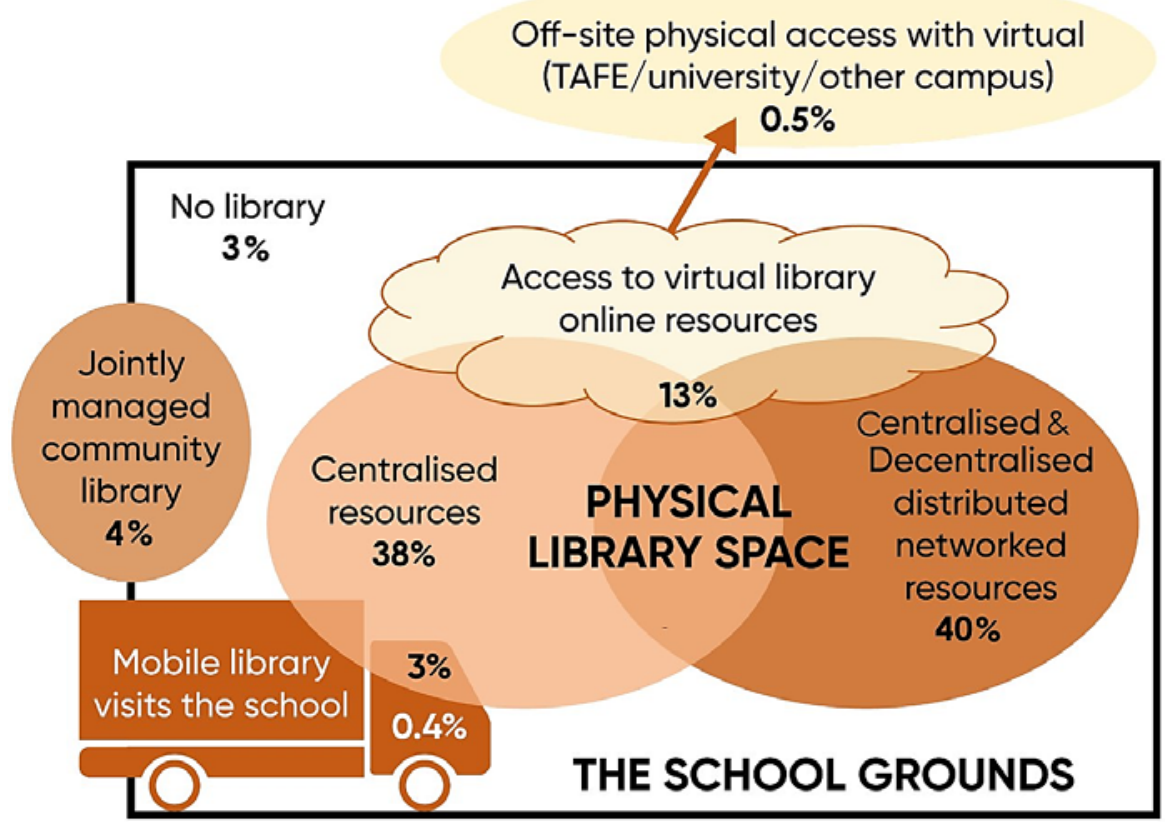




\section{Schools provide access to physical and networked resources}

Respondents were asked to describe what physical and networked resources their school provided in a dedicated area (excluding classrooms) for staff and students. Over $90 \%$ of schools have shelving and storage for shared resources, reading space or a service point for borrowing resources. Some $87 \%$ have a library staff work space and $82 \%$ have display space, while a quarter have a maker-space. Figure 23 presents the results. The number of physical resources in school libraries ranges from access to one physical resource in $2 \%$ of schools, to nine physical resources in $20 \%$ of schools. The majority of schools (86\%) have laptops, tablets or other portable digital devices. Other networked resources provided by schools are desktop computers: in labs or the library (52\%); in classrooms for staff use (32\%); and in classrooms for student use (30\%). A quarter of schools (24\%) use Bring Your Own Device.

The related line-graph in Figure 24 shows a significant relationship between the number of physical resources that a school has with how big it is $(r=0.25, p<0.01)$, such that larger schools tended to have more resources. Half the schools (50\%) provide 8-10 physical resources. Just over half the schools (54\%) provide 2-3 networked resources, with a further $27 \%$ providing only one type, resulting in a weaker relationship $(r=0.10, p<0.03)$ with school size regarding the average number of networked resources provided.

Figure 23. Percentage of schools having physical and networked resources provided in a dedicated area for staff and students ( $n=628$ )

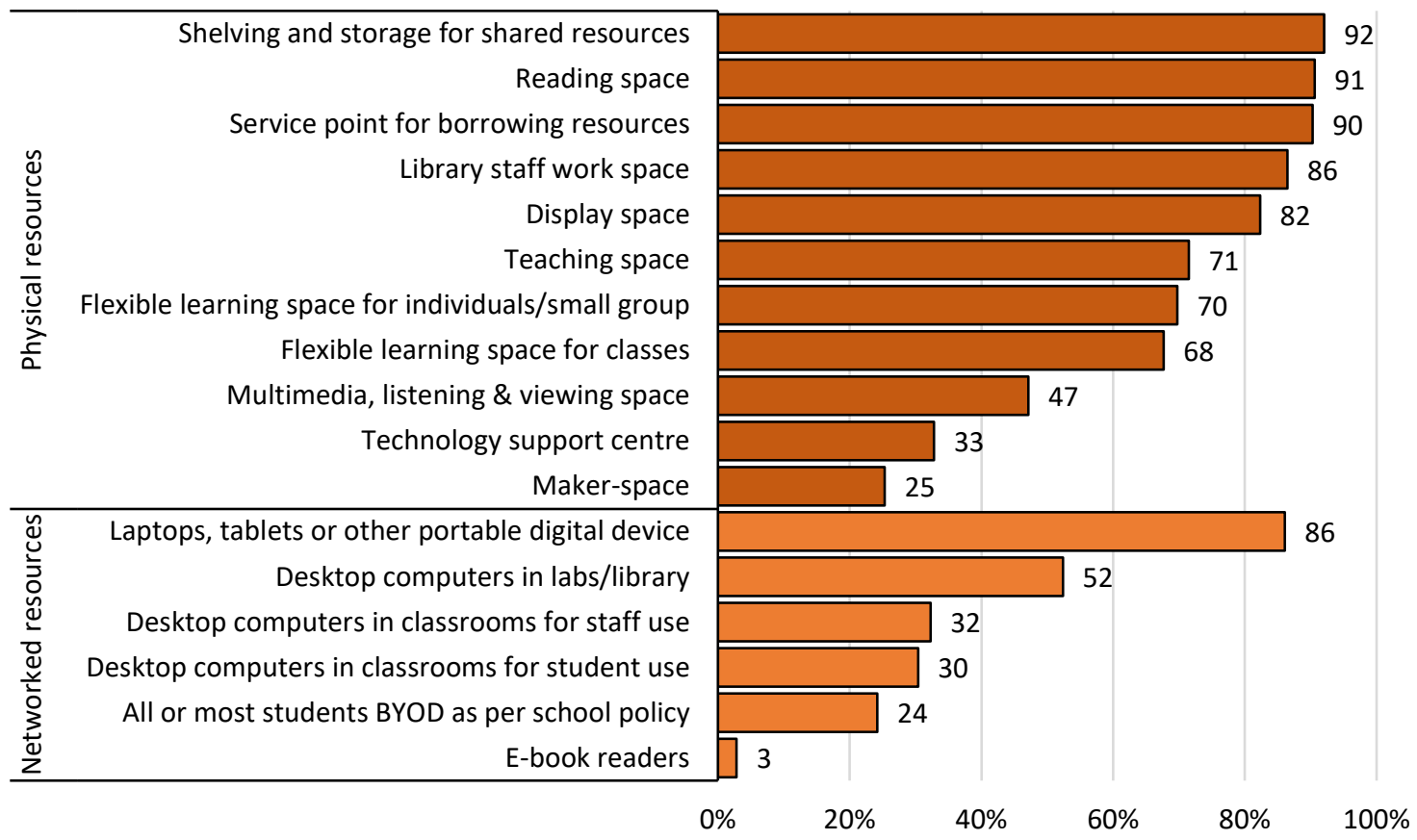


Figure 24. Average number of physical and networked resources provided in a dedicated area for staff and students by size of school $(n=628)$

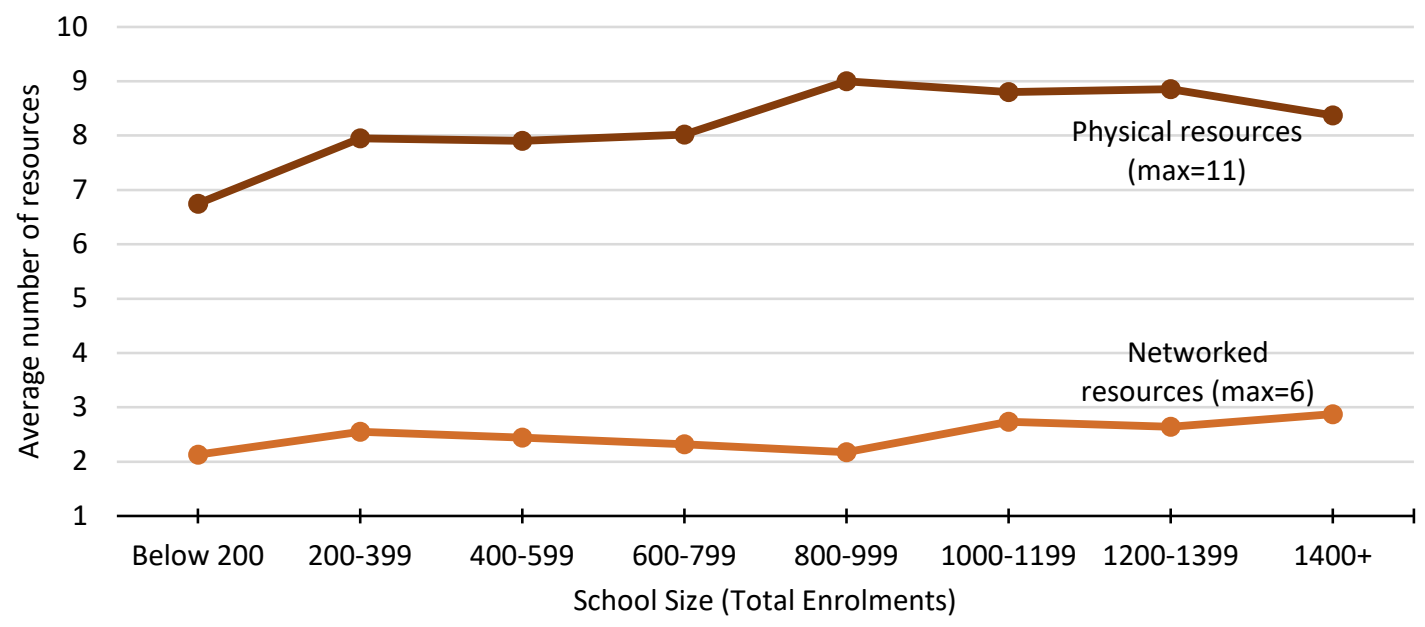

\section{Most schools use Bookmark and some have a dedicated library website}

While Figure 24 shows that almost $62 \%$ of schools, on average, use Bookmark as their library management system, the majority of schools are smaller primary schools (82\%). This is not surprising given that Bookmark library management software is created and owned by the South Australian Department for Education and supported for free to their schools. ${ }^{1}$ This dependence of South Australian schools on the Bookmark library management system, and the value it provides particularly to small, under-resourced schools, is worth noting. Centralised provision and support is cost-effective if the system supports contemporary resource management. There would be significant cost in staff time and professional development involved in implementing a new system across so many schools should this be required. The system used in school community libraries was variously reported as Sirsi Dynix, Symphony and One Card.

Larger secondary schools and combined K-12 schools are more likely to use Access-it (11\%). The system, Oliver, developed by Softlink, is used in 7\% of schools, in comparison to some other states (i.e. ACT, NSW and QLD) where it is provided to all schools in some jurisdictions.

\footnotetext{
1 http://bookmark.central.sa.edu.au/Support.htm
} 
Figure 25. What library management systems and digital learning resource services does your school have? ( $n=634)$

\begin{tabular}{|c|c|c|c|c|c|c|c|c|c|c|c|c|c|}
\hline & & & & & & & & & & & & & \\
\hline & \multicolumn{8}{|c|}{ School Size (Total Enrolments) } & \multicolumn{4}{|c|}{ School Type } & \multirow[b]{2}{*}{$\begin{array}{l}\text { Average } \\
\text { percentage } \\
\text { of schools }\end{array}$} \\
\hline & $\begin{array}{l}\text { 尺 } \\
\text { J } \\
3 \\
\frac{0}{0} \\
\infty\end{array}$ & $\begin{array}{l}\text { 尺े } \\
\text { } \\
\stackrel{1}{0} \\
\stackrel{\gamma}{ }\end{array}$ & 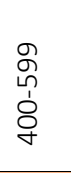 & $\begin{array}{l}\text { হ } \\
\text { 1 } \\
8 \\
8\end{array}$ & $\begin{array}{l}\text { बे } \\
\text { के } \\
\text { ᄋे } \\
\infty\end{array}$ & 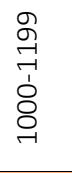 & 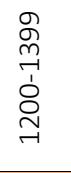 & 竎 & 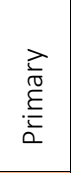 & 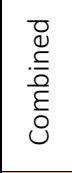 & $\begin{array}{l}\geq \\
\frac{\lambda}{\pi} \\
\frac{0}{0} \\
0 \\
0 \\
\dot{U} \\
\sim\end{array}$ & $\frac{\bar{d}}{\frac{1}{ \pm}}$ & \\
\hline \multicolumn{13}{|c|}{ Library management systems } & \multirow[b]{2}{*}{$3.3 \%$} \\
\hline None or not applicable & 6.0 & 1.2 & & 1.6 & 3.4 & 6.7 & 7.1 & 12.5 & 0.7 & 5.2 & 6.6 & 26.1 & \\
\hline Bookmark & 75.6 & 74.1 & 56.3 & 41.0 & 13.8 & 13.3 & 7.1 & 12.5 & 82.3 & 26.1 & 19.7 & 60.9 & $62.1 \%$ \\
\hline Access-it & 1.3 & 2.4 & 17.5 & 31.1 & 41.4 & 26.7 & 35.7 & 50.0 & 3.5 & 23.9 & 30.3 & & $10.9 \%$ \\
\hline Oliver & 1.7 & 7.1 & 10.7 & 8.2 & 17.2 & 13.3 & 35.7 & 12.5 & 5.2 & 11.2 & 10.5 & 4.3 & $7.1 \%$ \\
\hline Symphony/Workflows & 7.7 & 7.1 & 1.9 & 1.6 & & 6.7 & & & 1.0 & 19.4 & 5.3 & & $5.4 \%$ \\
\hline SmartSuite & 0.9 & 2.9 & 4.9 & 11.5 & 20.7 & 6.7 & & 12.5 & 2.5 & 4.5 & 14.5 & & $4.3 \%$ \\
\hline Amlib & 1.3 & 1.8 & 4.9 & 1.6 & 6.9 & 20.0 & 14.3 & & 1.7 & 5.2 & 6.6 & & $3.0 \%$ \\
\hline SirsiDynix/One Card & 2.6 & 2.9 & 1.0 & & & & & & 0.2 & 6.7 & 2.6 & & $1.9 \%$ \\
\hline Spydus & & 0.6 & 1.9 & & & 6.7 & & & 0.2 & & 3.9 & & $0.6 \%$ \\
\hline Destiny & & & 2.9 & & & & & & 0.5 & & 1.3 & & $0.5 \%$ \\
\hline OCLC Worldshare & 0.4 & & & & 3.4 & & & & & & 2.6 & & $0.3 \%$ \\
\hline Infiniti & 0.4 & & & & & & & & 0.2 & & & & $0.2 \%$ \\
\hline \multicolumn{13}{|c|}{ Digital learning resource services } & \\
\hline None or not applicable & 54.3 & 38.3 & 29.1 & 16.4 & 3.4 & & 7.1 & & 46.9 & 17.3 & 11.8 & 60.9 & $36.9 \%$ \\
\hline Library website & 15.1 & 20.4 & 27.2 & 45.9 & 58.6 & 66.7 & 71.4 & 62.5 & 16.6 & 49.6 & 42.1 & 13.0 & $26.6 \%$ \\
\hline Digital video platforms & 6.0 & 14.4 & 33.0 & 42.6 & 58.6 & 80.0 & 85.7 & 87.5 & 7.8 & 48.9 & 63.2 & 8.7 & $23.2 \%$ \\
\hline Apps management & 12.5 & 28.1 & 16.5 & 19.7 & 17.2 & 13.3 & 14.3 & 25.0 & 20.2 & 21.8 & 6.6 & 8.7 & $18.4 \%$ \\
\hline Subscription databases & 2.6 & 6.6 & 26.2 & 41.0 & 65.5 & 53.3 & 78.6 & 87.5 & 6.3 & 37.6 & 48.7 & 8.7 & $18.1 \%$ \\
\hline Ebook platforms & 4.7 & 9.6 & 14.6 & 23.0 & 31.0 & 40.0 & 42.9 & 50.0 & 5.0 & 30.8 & 25.0 & 4.3 & $12.9 \%$ \\
\hline Digital textbook services & 2.6 & 8.4 & 14.6 & 19.7 & 41.4 & 40.0 & 50.0 & 25.0 & 3.3 & 27.1 & 30.3 & 8.7 & $11.8 \%$ \\
\hline Digital magazines & 4.7 & 8.4 & 8.7 & 13.1 & 24.1 & 26.7 & 35.7 & 12.5 & 2.3 & 27.1 & 17.1 & 4.3 & $9.4 \%$ \\
\hline Library presence on social media & 5.2 & 10.2 & 10.7 & 9.8 & 17.2 & 6.7 & 28.6 & 25.0 & 4.5 & 20.3 & 15.8 & 4.3 & $9.2 \%$ \\
\hline Audiobook platforms & 5.6 & 5.4 & 6.8 & 9.8 & 27.6 & 33.3 & 35.7 & 25.0 & 2.5 & 26.3 & 11.8 & 4.3 & $8.7 \%$ \\
\hline Website curation & & 1.8 & 12.6 & 16.4 & 34.5 & 33.3 & 50.0 & 37.5 & 2.3 & 16.5 & 25.0 & 4.3 & $8.1 \%$ \\
\hline Services through SA public libraries & 0.9 & 1.8 & & & & & & & & 3.8 & & & $0.8 \%$ \\
\hline
\end{tabular}

Figure 25 also presents the digital learning resources and services that schools provide. Around $37 \%$ of respondents said that their school does not have digital learning resource services. However, $27 \%$ of schools report having a dedicated library website. This is similar to the number of schools reported earlier, as having a dedicated page (16\%) or subsection (11\%) about the library on their school public-facing website. This may reflect that schools have a 'private' library website, fire-walled and only visible once logged in through the school portal, as is more common and evident in the larger combined and secondary schools.

Direct comparison with the evidence of a school library based on the review of public-facing school websites offers further insight. Of the schools that highly promote their library on the public-facing school website (i.e. have a direct link to a dedicated page) or have a prominent or miscellaneous mention in a subsection, $68 \%$ report having a library website. For schools in which evidence of a library can only be found in parent handbooks or context statements, $30 \%$ have a library website. In comparison, for only $2 \%$ of schools with a library website, no evidence of an on-site library could be found on their public-facing school website. 
As Figure 25 also shows, $23 \%$ of schools use digital video platforms, while $18 \%$ provide apps management, and subscription databases (18\%), particularly if they are a large school. Access to these digital resources are also closely associated with the socio-economic status of the school, with high SES schools more likely to have library websites, digital video platforms and subscription databases. To ensure all students in the state have equitable access to core digital learning resources, there is scope for the South Australian government to negotiate state-wide subscriptions, such as those already in place for school community libraries through the South Australian Public Library Network.

\section{School libraries play their part in supporting curriculum priorities}

To further demonstrate the diversity of support and experience in what school libraries offer, Figure 26 shows that planning and managing school curriculum priorities is also part of the job. While classroom teachers and school leadership are the main planners and managers of curriculum, teacher librarians also contribute (keeping in mind that most people who manage the library are not qualified teacher librarians, as discussed in the next section). Five curriculum priority areas mainly managed by classroom teachers or curriculum leaders are: literacy and reading programs, information and digital literacy, digital technologies/STEM, cyber-safety and digital wellbeing, and enrichment learning. Whether the area is planned and managed by a classroom teacher or curriculum leader is associated with school type - typically a classroom teacher in primary school and a curriculum leader or faculty head in secondary or combined schools.

Figure 26. Percentage of schools in which various staff are mainly responsible for planning and managing the following curriculum areas $(n=560)$

\begin{tabular}{|c|c|c|c|c|c|c|}
\hline & $\begin{array}{l}\text { Teacher } \\
\text { Librarian }\end{array}$ & $\begin{array}{l}\text { Curriculum } \\
\text { leader or } \\
\text { Faculty head }\end{array}$ & $\begin{array}{l}\text { Classroom } \\
\text { teacher }\end{array}$ & $\begin{array}{c}\text { Shared } \\
\text { planning \& } \\
\text { instruction }\end{array}$ & Other & $\begin{array}{c}\text { No one, } \\
\text { it's not a } \\
\text { priority }\end{array}$ \\
\hline Average & $12 \%$ & $21 \%$ & $40 \%$ & $13 \%$ & $8 \%$ & $7 \%$ \\
\hline Digital technologies/STEM & $2 \%$ & $33 \%$ & $45 \%$ & $12 \%$ & $6 \%$ & $2 \%$ \\
\hline Literacy and reading program & $6 \%$ & $39 \%$ & $35 \%$ & $14 \%$ & $4 \%$ & $2 \%$ \\
\hline $\begin{array}{l}\text { Cyber-safety and digital } \\
\text { wellbeing }\end{array}$ & $3 \%$ & $34 \%$ & $34 \%$ & $11 \%$ & $15 \%$ & $3 \%$ \\
\hline $\begin{array}{l}\text { Research, study skills, inquiry } \\
\text { learning }\end{array}$ & $18 \%$ & $9 \%$ & $55 \%$ & $13 \%$ & $3 \%$ & $3 \%$ \\
\hline Information and digital literacy & $10 \%$ & $24 \%$ & $41 \%$ & $14 \%$ & $7 \%$ & $4 \%$ \\
\hline Referencing skills & $20 \%$ & $4 \%$ & $52 \%$ & $11 \%$ & $4 \%$ & $9 \%$ \\
\hline Enrichment learning & $11 \%$ & $17 \%$ & $23 \%$ & $18 \%$ & $16 \%$ & $15 \%$ \\
\hline $\begin{array}{l}\text { Copyright/Creative Commons } \\
\text { and ethical use of information }\end{array}$ & $23 \%$ & $10 \%$ & $33 \%$ & $8 \%$ & $11 \%$ & $15 \%$ \\
\hline
\end{tabular}


The three curriculum priority areas of research, study skills, inquiry learning (18\%); referencing skills (20\%); and, copyright/Creative Commons and ethical use of information (23\%) are more likely to be planned and managed by a teacher librarian. This is more likely to be true in high socio-economic status secondary or combined K-12 schools. There is also an association with library-type and the curriculum priority areas of information and digital literacy, referencing skills and, copyright/Creative Commons and ethical use of information. Respondents from schools with mobile library access (either alongside on-site access or solely mobile access) are far more likely to say that both information and digital literacy and referencing skills are mainly managed by a classroom teacher. Respondents from schools with virtual and on-site library access are more likely to say that information and digital literacy, referencing skills and copyright/Creative Commons and ethical use of information are mainly managed by a teacher librarian. Those respondents from schools with decentralised (non-central) on-site library resources are more likely to say that referencing skills are mainly managed by a curriculum leader or faculty head.

\section{School libraries are a safe place and a central hub that support curriculum}

School libraries typically provide a central hub for the school, along with a range of supporting activities. This is captured in the following comment.

The library is a hub for students to enjoy the love of reading and students are pointed in directions of books of interest and research. It is a multi-use area that is enjoyed and used at all times by students and teachers (Regional primary school).

The census results in Figure 27 show that almost all school libraries offer a safe space for students (91\%), and host special events (88\%). More than four in five school libraries arrange the selection and purchasing of relevant, quality learning resources on behalf of the wider school community (84\%), or manage access to the school's resource collection (including multi-media, 84\%). Twothirds of libraries provide a central learning hub for the school (63\%) and support students to develop a love of reading through reading programs (62\%).

Figure 27 also shows other services the library provides to the school, related to supporting curriculum and teaching. Around $84 \%$ of schools provide curriculum resource support to teachers. Half the schools report that their library teaches research/inquiry skills, information and digital literacy to students (51\%), and one-third support collaborative planning and instruction of learning and assessment (32\%).

When asked what other teaching-related activities occurred as part of their library services in the school, many libraries offer other supporting activities, as Figure 27 also shows. Half the libraries offer flexibly timetabled lessons with library staff as required (52\%), and 39\% of libraries offer collaborative planning with teachers. Fewer libraries provide professional learning for staff (34\%) or engage in supporting action research (32\%). These activities are associated with school context, as the following comment depicts.

The library houses around 27000 books in the Middle/Senior School and around half that number in the Junior School. The library hosts relevant activities (Book Weeks, PRC etc) and supports the 7-12 reading programme. The library is popular as a study space and borrowing has increased in the last couple of years (Metropolitan College). 
Figure 27. Which services and support does your library provide? Percentage of schools ( $n=632$ )
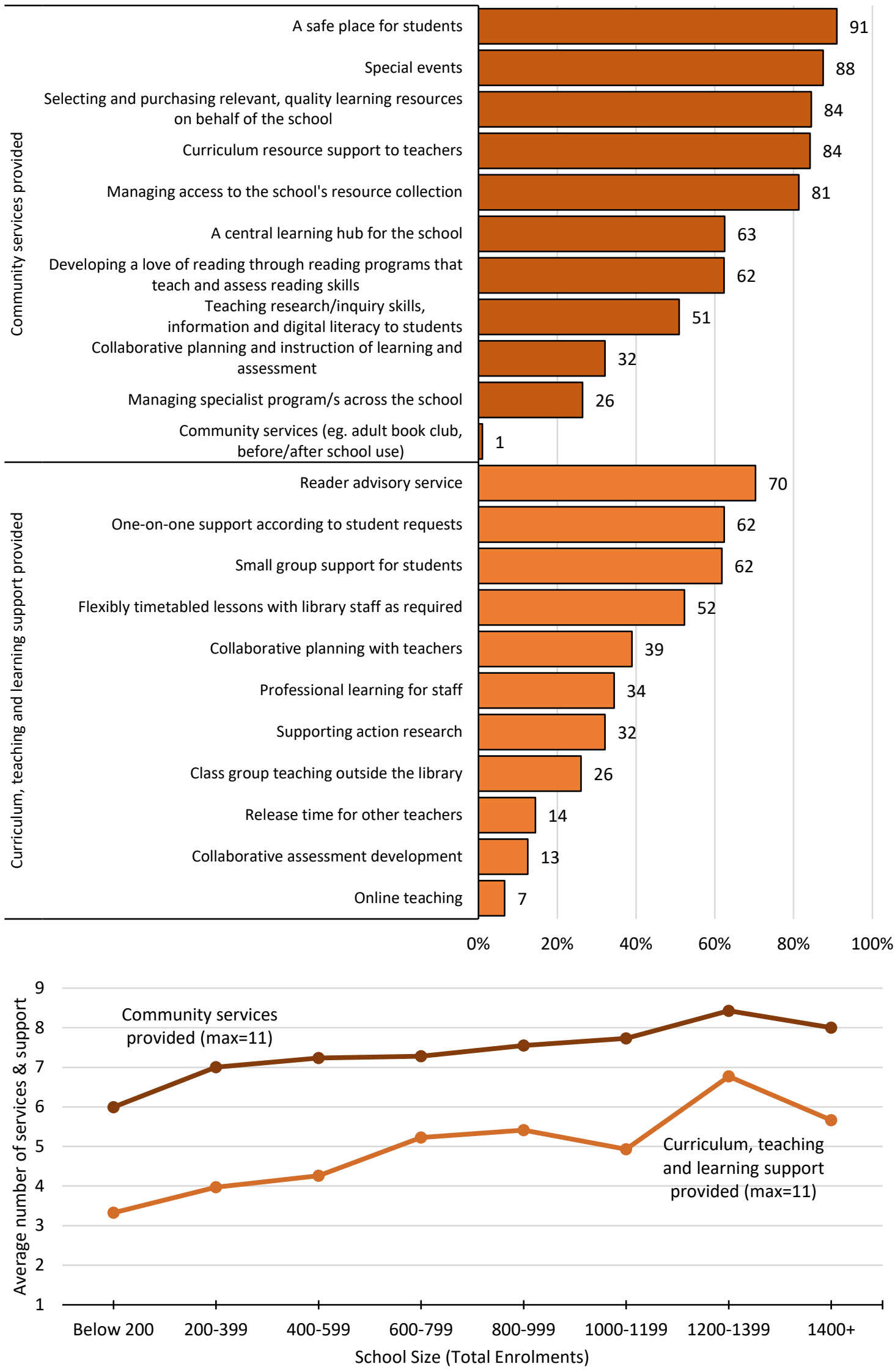
High SES schools in metropolitan areas are more likely to offer flexibly timetabled lessons with library staff and collaborative planning with teachers. Whereas secondary or combined schools in metropolitan areas are more likely to offer professional learning for staff and support action research. In addition to supporting teachers, libraries also supplemented student learning, with $70 \%$ offering reader advisory services (helping students to find their next book), and $62 \%$ offering one-on-one support according to student requests, or small group support for students.

The related line-graph also shown in Figure 27, indicates there is a significant relationship between school size and the number of community services $(r=0.26, p<0.01)$ and curriculum, teaching and learning support $(r=0.32, p<0.01)$ the school library provides. Larger schools tend to provide more services and support. Around half the schools provide 4-7 types of service (50\%) and 3-6 types of support (52\% of schools). Schools with 1200-1400 students provide eight services and seven types of support, on average, all of which are implemented by dedicated library staff as the following comment indicates.

The library staff act as 'teachers' in one sense, offering advice in timetabled lessons about resourcing and referencing to multiple year levels. The library also offers sessions for teachers, educating them on the features that are offered, on-line and within the four walls of the library (Metropolitan combined $\mathrm{K}-12$ school). 


\section{A CULTURE OF SUPPORT}

The school library acts as a centre for learning, research and student wellbeing managed by committed, experienced and keen staff and professionals who are adapting, transforming, trialling and collaborating, more than ever before, to embrace challenge and change to harness opportunities that improve educational outcomes (Curtis, 2017). Research indicates that knowledgeable principals who are supportive leaders recognise how libraries can contribute to learning (Hartzell, 2002a, 2002b). In effective schools, library managers are a respected and valued member of the school leadership team with the mandate to promote reading and library use, and directly drive school-wide programs to support reading and literacy (Ofsted, 2006; IFLA, 2015).

\section{School leadership support}

Principals' perceptions of school libraries and teacher librarians are vital for creating a positive, collaborative climate and rethinking the role a library can play for improving young people's life outcomes (Church, 2010; Hartzell, 2002b; Lupton, 2016; Shannon, 2009). Research has shown a strong relationship between student attainment and the degree to which the principal values and supports the library media program (Lance, Rodney \& Russell, 2007; Scholastic, 2016). As "everybody's teacher" (Gavigan \& Lance, 2015) in the "biggest classroom in the building" (Kuon, Flores \& Pickett, 2014, p. 65), the teacher librarian and school library warrant particular attention from school leaders. Four aspects tend to shape the way principals think about their school's library: their own experiences in school libraries as children, in which they presumed the library to be peripheral to the classroom; their professional training on the library's connection to curriculum and teaching; the nature of the teacher librarian's work, which is to support and empower others; and the low profile teacher librarians and school libraries have in literature read by pedagogical staff, which restricts their sense of what the library really is and can do (Hartzell, 2002a).

In order to broadly gauge the school library and information services in terms of how effective and valued they were by their community, respondents were asked to rate four statements about whether the library was supported by leadership, effectively managed, staffed and funded.

Figure 28 presents the results and suggests that 60\% of respondents (some of which are principals) rate the services as 'completely' supported and backed by school leadership. A further $27 \%$ feel that their library is 'moderately' supported by school leadership. This is reflected in the following comment.

Our library is a hub for students across all year levels. Primary students have scheduled lesson times where they are encouraged to develop their reading skills for proficiency and enjoyment. Our library also facilitates programs such as Literacy Pro (Lexiles), conducts maker-space sessions, supports curriculum with relevant material, promotes reading with activities such as Premier's Reading Challenge and Book Week. The library is utilised by many students at lunchtimes for a safe, familiar place to enjoy quiet time, activities and interaction with library staff. Our library is well resourced and supported by school management (Regional College). 
Over half the schools report that their library is completely effectively managed (56\%) and a third are effectively funded (36\%) and staffed (31\%).

Figure 28. Percentage of school library services supported by school leadership ( $n=623$ )

\begin{tabular}{|c|c|c|c|c|c|}
\hline \multirow[b]{2}{*}{ Supported and backed by school leadership } & \multicolumn{2}{|c|}{$\square$ Somewhat } & \multicolumn{2}{|c|}{$\square$ Moderately well } & $\square$ Completely \\
\hline & 11 & 27 & & 60 & \\
\hline Effectively managed & 7 & 36 & & 56 & \\
\hline Effectively funded & 4 & 20 & 39 & & 36 \\
\hline Effectively staffed & 5 & 21 & 43 & & 31 \\
\hline
\end{tabular}

\section{School library and information services are valued}

In an ideal world, principals want their library staff to collaborate and teach $21^{\text {st }}$ century skills (Lance \& Kachel, 2018), know and understand the Australian Curriculum standards, connect library teaching with classroom instruction, promote reading and literacy (Merga \& Gardiner, 2018), teach technology skills, provide professional development for educators, create welcoming learning environments in their libraries, be approachable, enthusiastic, and innovative; and interact positively and proactively with the staff (Church, 2010). A more recent study in Australia has found that principals value the role of teacher librarians but often see them as a teacher first and then as a librarian (Lupton, 2016). However, as the author points out, this simplified view of the role can cause some confusion as teacher librarians are evaluated using the Australian Professional Standard for Teachers (AITSL, 2018), which are based on a generic profile that does not take into account the specialised role of a teacher librarian (Lupton, 2016).

There is a growing realisation of the importance of reading culture and habits in developing literacy (Loh, Ellis, Paculdar \& Wan, 2017; Mangen \& van der Weel, 2016).

Students who are highly engaged in a wide range of reading activities and use learning strategies that facilitate deeper levels of learning are more likely than other students to be effective learners and perform well at school (Thomson, Hillman \& De Bortoli, 2013, p. 45).

To gain a picture of how school library and information services are valued by their community, respondents were asked to rate four statements about whether the library was valued by community, well resourced, and contributed to improved student outcomes. Figure 29 presents the results. Half the schools 'completely' agree that their library services provide resources equitably across the school community, and a similar proportion (49\%) completely agree that their library is valued by the school community. Around $40 \%$ report that their library is completely contributing effectively to student learning, while $35 \%$ believe it to be well-resourced and current. 
Figure 29. School library and information services valued by the community ( $n=623$ )

\begin{tabular}{|c|c|c|c|c|}
\hline$\square$ Not at all & \multicolumn{2}{|c|}{$\square$ Somewhat } & $\square$ Moderately well & $\square$ Completely \\
\hline $\begin{array}{l}\text { Providing resources equitably across the school } \\
\text { community }\end{array}$ & 9 & 41 & & 50 \\
\hline Valued by the school community & 13 & 38 & & 49 \\
\hline Contributing effectively to student learning & 13 & & 45 & 41 \\
\hline Well-resourced and current & 15 & & 48 & 35 \\
\hline
\end{tabular}

\section{Factors affecting or reflecting being supported and valued}

Throughout this report we have considered to what extent contextual factors influence school libraries and their staffing. Earlier, we also hypothesised that library and information services valued by schools may be reflected in their presences and promotion on the school public-facing website. To test this and other contextual factors, we examined to what extent the views about being supported by school leadership and valued by community are affected or reflected by context. Figure 30 presents the results of respondents' average overall rating across the respective items comprising the two measures. It presents clear relationships between views and school size, school type, SES, budget allocation, library management, and website visibility. The strengths of association were tested using Pearson correlation. The results suggest that school library and information services are significantly more likely to be supported by school leadership if they are larger $(r=0.12, p<0.01)$, well-funded $(r=0.28, p<0.01)$, managed by a qualified teacher librarian or library-qualified SSO/ESO $(r=0.18, p<0.01)$, and are highly visible on the school website $(r=0.09, p<0.05)$. Similarly, school libraries are significantly more valued by their community if they are larger $(r=0.09, p<0.05)$, a primary school $(r=0.09, p<0.05)$, well-funded $(r=0.28, p<0.01)$, managed by a qualified teacher librarian $(r=0.17, p<0.01)$, and are highly visible on the school website $(r=0.12, p<0.01)$.

In response to Herring's (2007, p. 39) statement, this evidence does indeed suggest that libraries that "are visible as part of the school website" do reflect "the value which the school places on the school library". 


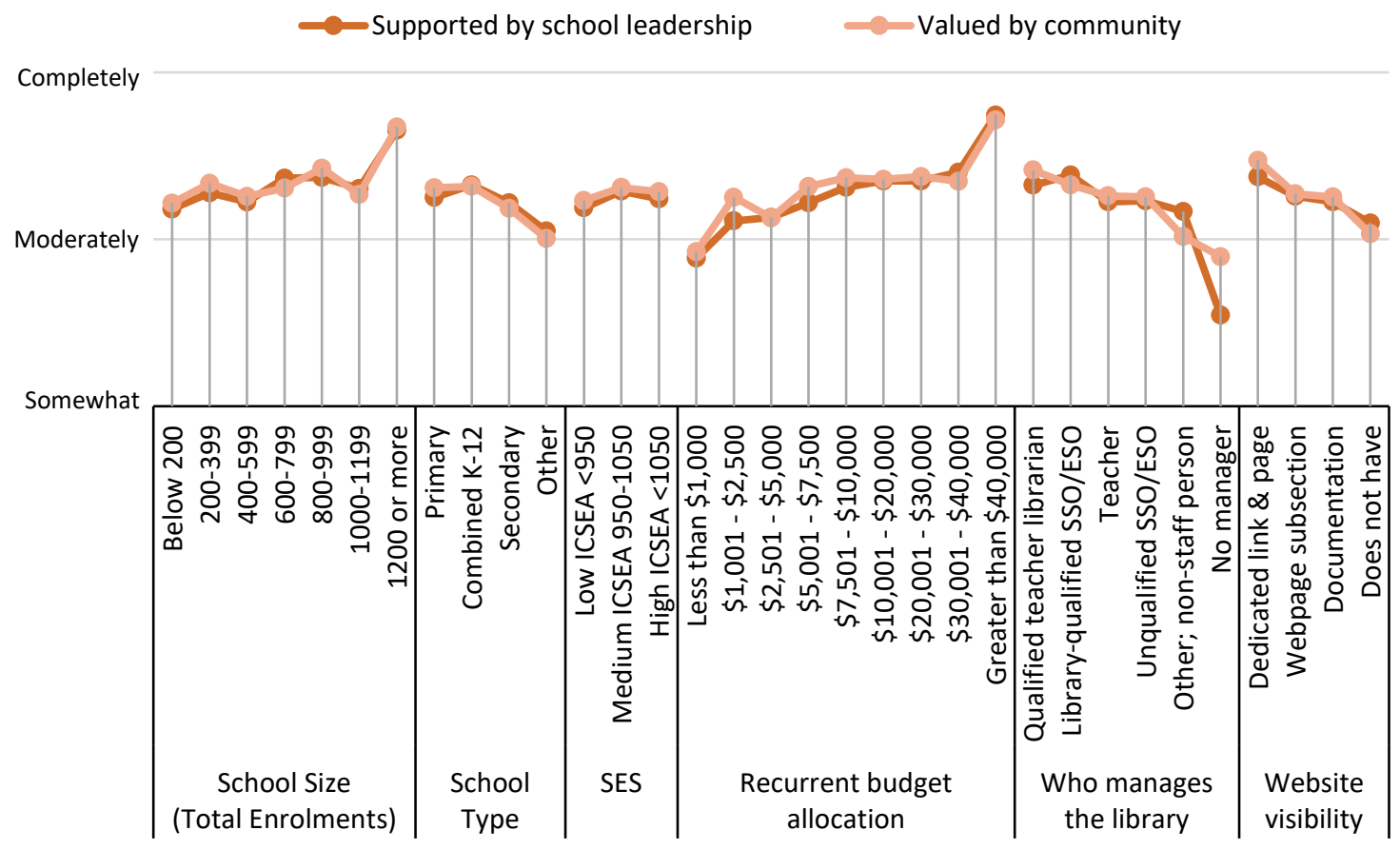

While school leadership can't influence their school's size, type, or the community's SES status, they can have influence over how their library is funded, who manages the library, and to what extent they publicly promote their library and information services on the school website. For example, it would be unusual for a 'Principal's Tour' of the school not to include the school library resource centre as part of the tour, along with the gym, art centre or other assets the school may have and wish to proudly promote. To what extent these factors are affecting or reflecting how supported and valued a school library is, remains to be answered. Either way, there is a clear opportunity for many South Australian schools to reconsider how they value and support their school library and information services. One relatively simple step is to recognise the school library and information services as an important asset to the school and reflect this in the visibility it has on the school's public-facing website. Raising the profile of the school library, may in turn, raise awareness both within and beyond the school walls. A community that supports and values its school library services, tends to support and value reading, literacy and scholarship more broadly, leading to better student academic and wellbeing outcomes. 


\section{WHAT A $21^{\text {ST }}$ CENTURY SCHOOL LIBRARY LOOKS LIKE}

The 21st century school library is a teaching and learning centre situated in a sophisticated information and technology environment that challenges learners to use information sources with help from an instructional team, and with funds allocated from school budgets and secured from external sources (Gordon, 2015, pp. 1-2).

The 2016 edition of the School Libraries Work! acknowledges that school libraries can be at the core of today's rapid innovation and changes by promoting and facilitating the learning of essential and evolving 21st century skills (Scholastic, 2016). ALIA (2017) describes ten ways that libraries power high performance schools.

1. Create a modern learning environment

2. Build a digital hub

3. Improve research skills

4. Encourage reading for pleasure

5. Provide curriculum support
6. Advice on cyber safety

7. Support diversity

8. Promote participation and access

9. Coordinate special programs

10. Build the community

For a library to add value to the teaching and learning program in a school, it is important that in addition to being adequately funded and properly resourced, it is staffed with teacher librarians who have a thorough understanding of the Australian Curriculum, and are able to interact with teachers and learners using current technology by acting as partners, educators, resource aggregators, literacy advocates, and technology innovators (ASLA, 2013). Therefore, the main elements for an effective school library learning space comprise a combination of physical spaces and virtual collections, staff and the roles they play, funding and budget support - all of which are influenced by the school's background characteristics. With the current pace of innovation and change students and teachers are discovering new ways to use technology to collaborate, teach, and learn and the school library is expected to support this transformation. This may involve a traditional library evolving to a learning commons for teaching and learning of 21st century skills (CSL, 2018, 2019; Scholastic, 2016).

Modern school libraries also train teachers and students to develop independent searching skills and become "discerning users of resources" (Mitchell, 2011). The role of the teacher librarian is important if this is to be effective. In an information age with the easy convenience of free access platforms, a core responsibility for a school library is to educate the students about internet safety, trustworthy sourcing and responsible and safe use of easily accessible data. Qualified teacher librarians can be that guide for students and staff. Additionally, they can work with other teachers and train students in research-based learning techniques which support the curriculum.

In an ideal world, a teacher librarian co-teaches with other members of the pedagogical staff and adds their expertise to the planning and application of teaching and learning activities (IFLA, 2015). A model of how teacher librarians can contribute to teaching and learning is presented in Figure 31. Importantly, teachers may need to be reminded that librarians can serve as instructional partners, and training in joint-instruction is required to achieve this collaboration (Montiel-Overall \& Grimes, 2013). 
Figure 31. How teacher librarians can support classroom activities

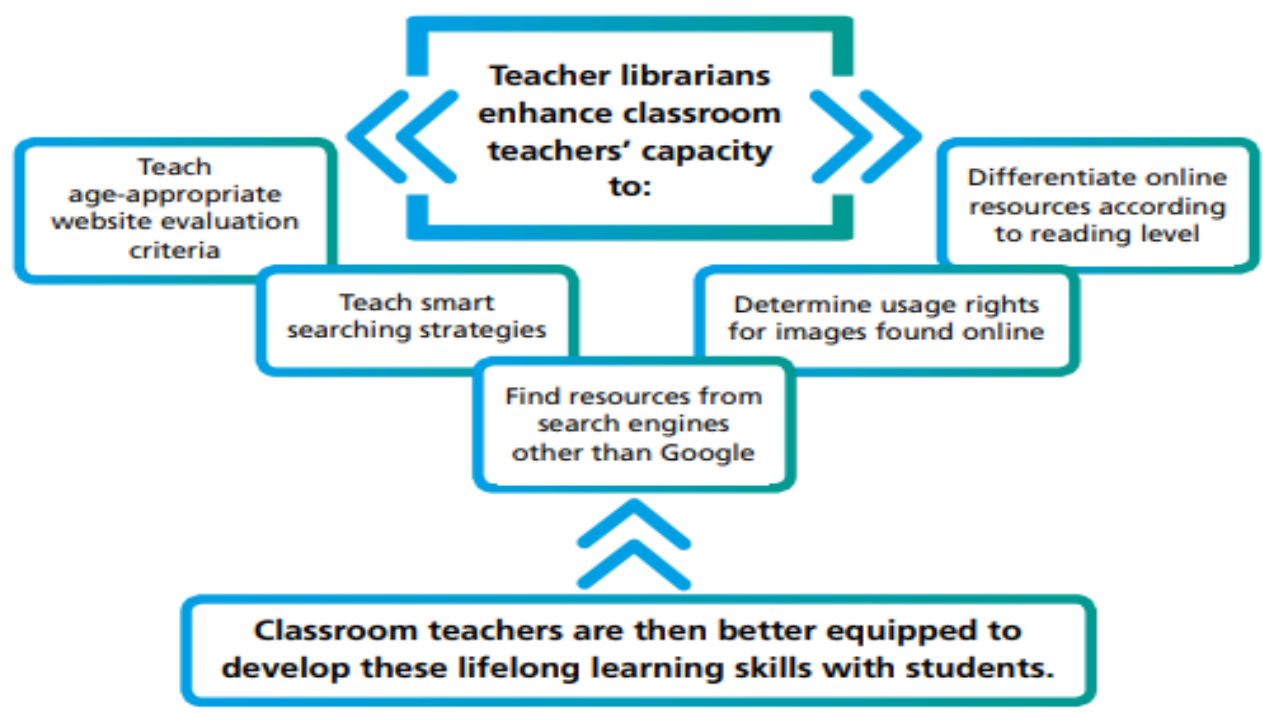

Source: (C) Australian Capital Territory (2019, p. 8)

Rather than teacher librarians operating as independent silos it is important for principals, learning coordinators and teacher librarians to meet, plan, and frame strategies for getting teacher librarians involved in meeting school curriculum goals (Lance \& Kachel, 2018) to realise their capacity to support schools to achieve their curriculum goals.

Teacher librarians are in a unique position to see the big picture of the curriculum, and by making the most of this 'helicopter view' can help identify silos and make connections 'on the ground' (Mitchell, 2011, p. 13).

A teacher librarian's broad overview of the curriculum is useful to the entire school community as they can provide tailored and differentiated resourcing support to the staff, students and parents (ACT Government Education, 2016). A teacher librarian with welldeveloped skills of leadership, collaboration and communication, combined with strong interpersonal skills can build a good relationship with key stakeholders in the school community. Another key role of school libraries and teacher librarians play is to help people engage in conversations regarding resourcing the curriculum. Their dual-qualification provides specialist knowledge in the selection and promotion of resources for educational purposes, including literacy development, digital resources and reading for enjoyment, and wellbeing (Mitchell, 2018).

The information needs and technological advances of current times have created additional roles for the library staff. For example, new positions are being created in schools to support and coach classroom teachers in using digital resources and emerging technologies; and these new positions come with titles such as "digital integrationist, innovation specialist, digital learning specialist, reading interventionist, and technology integration coach" (Lance \& Kachel, 2018). A teacher librarian's familiarity with current and emerging digital technologies and understanding of research skills, can influence teaching and learning within the school (ASLA, 2013). Library staff in schools are in an excellent position to support other staff and students in use of technology. 
And because librarians work directly with all teachers and all students, they have a big picture view that can make them major assets on leadership committees that assess curriculum, technology, and other programs that affect the entire school community (Lance \& Kachel, 2018, p. 18).

These ideas about the functions of a school library and school-librarian were summarised by Todd and Kuhlthau (2004) in their model of school library as a dynamic agent of learning, depicted in Figure 32. This model covers the major functions of a school library which include acting as informational, transformational and formational space (Scholastic, 2008).

- Informational - this includes physical/digital collections and information technology infrastructure. School libraries keep the curriculum and reader groups in mind when gathering their collections.

- Transformational - which includes collaborations with other pedagogical staff to develop instructional interventions. Building technological skills for students and staff is a part of this function as is planning strategies to promote and encourage reading. Overall, this function plays the central role in creating good library programs.

- Formational - this is a longer-term function which is attained through the effective implementation of the other functions. Student outcomes such as knowledge creation, use and dissemination when students apply their acquired skills to undertake research or inquiry-based learning is the main goal here.

Figure 32. Todd \& Kuhlthau's Model of school library as a dynamic agent of learning

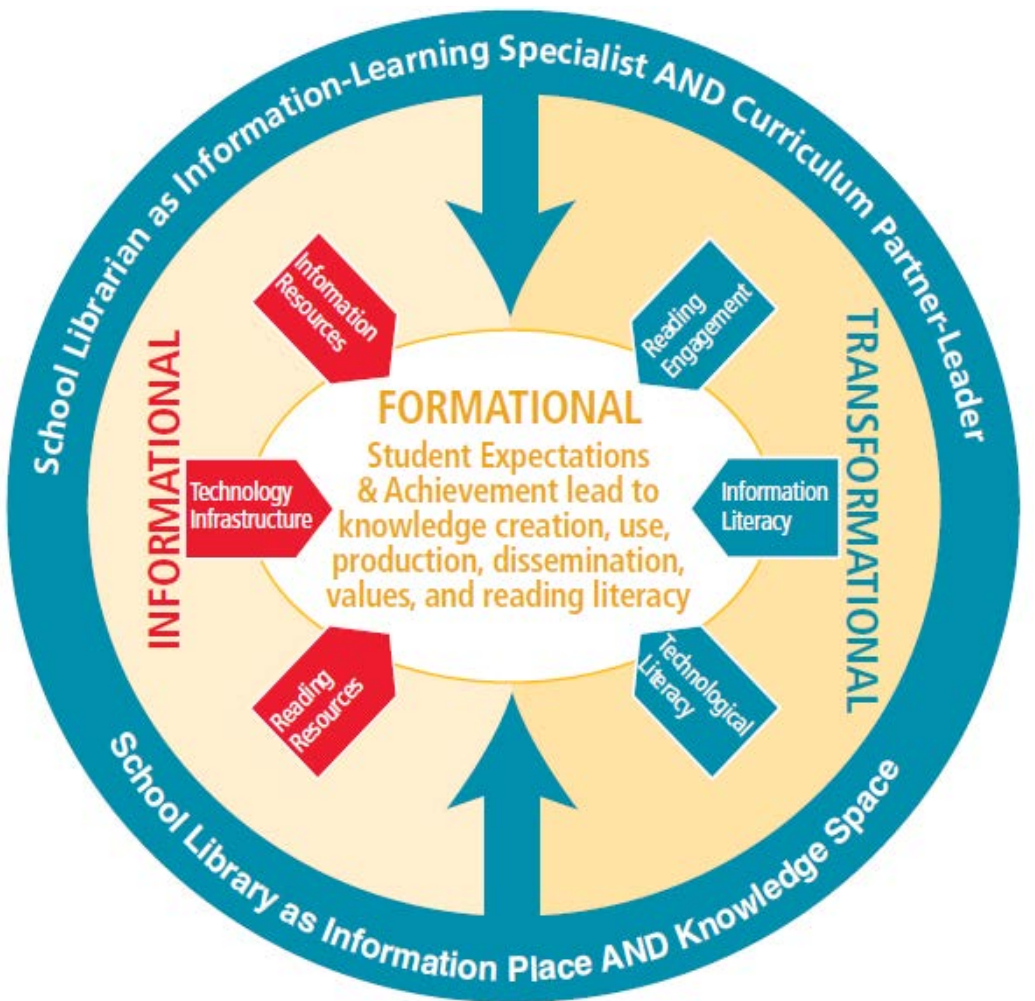

Source: (CTodd, Kuhlthau \& OELMA. (2004). Reproduced from Scholastic (2008, p. 22). 
Figure 33 shows a similar model, developed in Canada more recently, which also takes into account technological influences. The main idea is that learners of the $21^{\text {st }}$ century need an "excellent physical and virtual school library learning commons" which provides a safe environment with diverse resources and at the same time is well equipped with staff to provide active learning experiences through collaboration with the teaching staff and a thorough understanding of the school curriculum (CSL, 2019). This model is based on the Leading Learning Standards of Practice for Effective School Library Learning Commons in Canada (CSL, 2018).

Figure 33. Student Success and the School Library Learning Commons

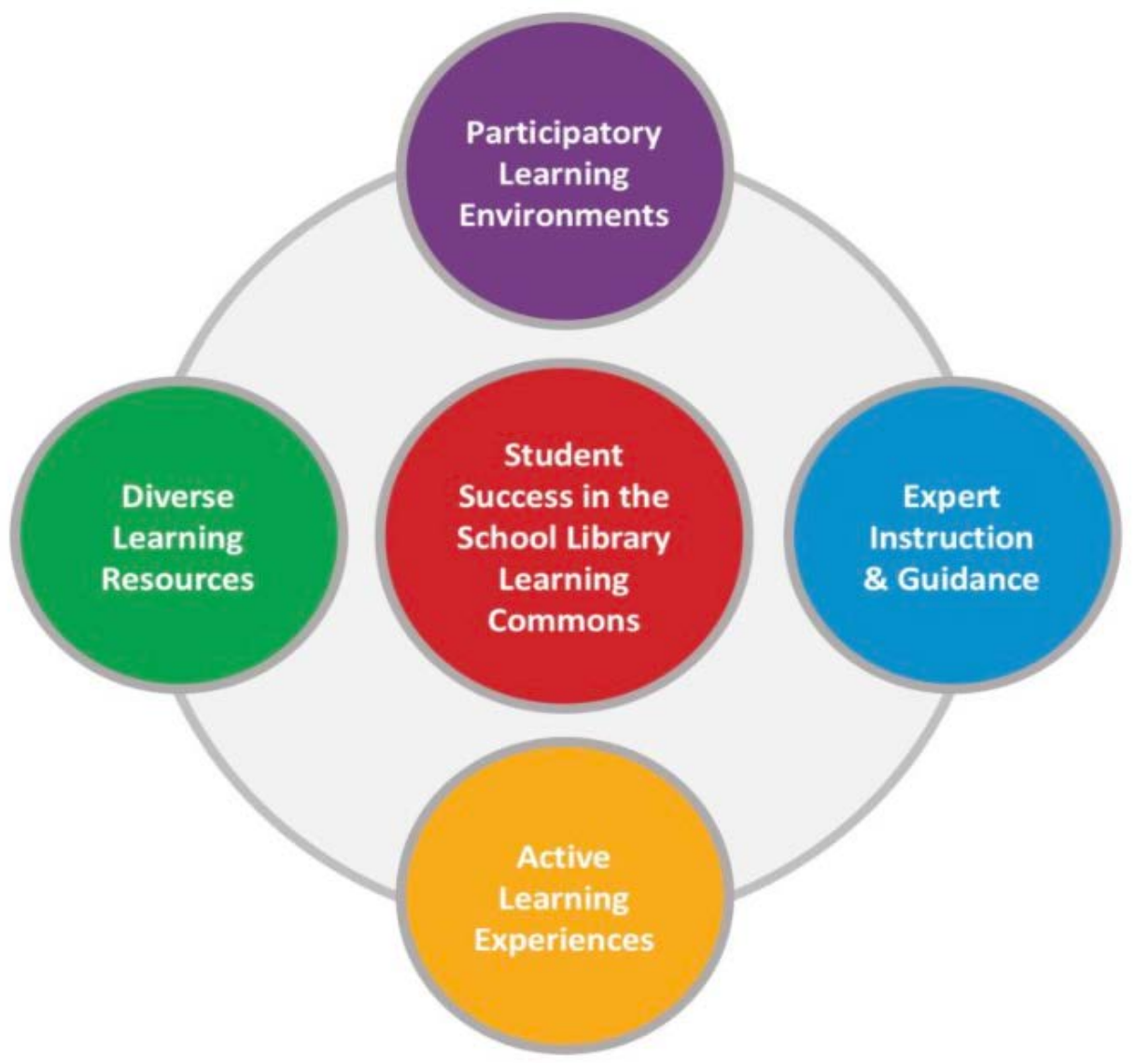

Source: Canadian School Libraries (2019). Excellent school libraries. CC-by-nc 4.0

Based on the literature and the models developed in other countries, a guideline is presented in Table 4, which summarises key features that are present in an effective school library. The development of this guideline was mainly built on the recommendations from the 2016 edition of the School Libraries Work! (Scholastic, 2016). 
Table 4. A guideline for an effective contemporary school library

\begin{tabular}{|c|c|c|}
\hline \multicolumn{2}{|l|}{ Factors } & Functions and roles of a contemporary library \\
\hline $\begin{array}{l}\text { School } \\
\text { background } \\
\text { and funding }\end{array}$ & $\begin{array}{l}\text { - School type and sector } \\
\text { - School location } \\
\text { - School SES } \\
\text { - School size } \\
\text { - Funding (budget allocations, } \\
\text { voluntary parent } \\
\text { contributions or other } \\
\text { donations, fundraising) }\end{array}$ & $\begin{array}{l}\text { School type, sector, location, size, SES all influence the quality } \\
\text { of students the school will attract, which in turn affects funding } \\
\text { - Financial and programmatic support by the educational } \\
\text { community to achieve the mission of the school }\end{array}$ \\
\hline $\begin{array}{l}\text { Senior } \\
\text { management } \\
\text { support }\end{array}$ & $\begin{array}{l}\text { - Supportive leadership } \\
\text { - Professional development }\end{array}$ & $\begin{array}{l}\text { Provide leadership for achieving school missions, objectives, } \\
\text { and policies for building a participatory school culture } \\
\text { Create opportunities for teachers and school librarians to } \\
\text { collaborate on projects that help students use a variety of } \\
\text { resources, conduct research, and present their findings }\end{array}$ \\
\hline $\begin{array}{l}\text { Facilities \& } \\
\text { collections }\end{array}$ & $\begin{array}{l}\text { - Physical and virtual space } \\
\text { - Collection } \\
\text { Technology and equipment }\end{array}$ & $\begin{array}{l}\text { A safe supportive and nurturing setting and network } \\
\text { environment } \\
\text { A virtual learning area available to everyone from any place and } \\
\text { from any device } \\
\text { - Combination of technology, teaching, and learning resources/ } \\
\text { equipment } \\
\text { - Access to the physical space before, during and after school } \\
\text { hours } \\
\text { - Resources based on the learning needs of all students } \\
\text { - Resources to build on state and national standards } \\
\text { Resources that supplement the school curriculum }\end{array}$ \\
\hline Staffing & $\begin{array}{l}\text { Number of full-time/part } \\
\text { time library staff } \\
\text { Qualifications and } \\
\text { experience } \\
\text { - Additional library support } \\
\text { staff }\end{array}$ & $\begin{array}{l}\text { Promote reading by matching students to books/ resources } \\
\text { (including print, audio, and e-books) } \\
\text { - Organize, manage, and maintain a collection of valuable } \\
\text { resources that are also useful for the future } \\
\text { - Share the findings of reading research with teachers } \\
\text { - Promote resources and activities that spark student interest in } \\
\text { reading, learning, and achievement for all school years } \\
\text { - Teach information skills and inspire students to independently } \\
\text { seek, access, and use information } \\
\text { - Manage information by providing intellectual and physical } \\
\text { access to information in print, media, and online resources, } \\
\text { either local or web-based } \\
\text { - Train staff and students on responsible information use and } \\
\text { cyber safety } \\
\text { - Encourage classroom teachers to incorporate literature and } \\
\text { information skills into the curriculum } \\
\text { - Provide combined programs for reading instruction } \\
\text { Work together with teachers regularly to provide resources and } \\
\text { activities for course, unit, and lesson integration } \\
\text { Work in partnership with teachers to meet the intellectual } \\
\text { needs of students }\end{array}$ \\
\hline
\end{tabular}

Source: Based on information from School Libraries Work! (Scholastic, 2016). 
Ultimately, the role of school libraries is to encourage young people to create new knowledge and meaning from the world around them and this is done effectively by extending the physical space with digital resources and up-to-date technology to create innovative learning hubs (Holland, 2015), as reflected in this comment from a South Australian census school.

Our library is an R-10 library that caters for approx. 650 students, 40 teachers/staff and some parents when applicable. We also manage the maths equipment, readers, class sets, cameras, photocopiers, laptops, lunchtime activities, before and after school borrowing, learning spaces, book week activities, daily collection and delivery of library resources to/from classrooms, book club, and Premier's Reading Challenge. Along with purchasing and processing all resources for borrowing for both staff and students. The library is an integral part of our school as it provides a safe space for all who use it and the staff who work there are respected for the job they do (SA metropolitan college). 


\section{CONCLUSION}

The census specifically aimed to collect data on areas related to staffing, support, facilities, and funding, guided by two overarching research questions:

1. What is the profile of school library staffing in South Australia?

2. What are the factors that influence school libraries and their staffing?

The 2019 snapshot has yielded, for the first time, reliable and representative 'hard data' about school library and information services in South Australia, with the view to informing future policy and funding decisions.

It is surprising that this data is not already available. It is strongly recommended that South Australian education systems update their reporting requirements so that schools provide specific data on school library staffing and resourcing on a regular basis. This will allow all stakeholders to identify trends in the provision of school libraries locally and facilitate policy decisions based on data.

\section{RECOMMENDATIONS}

\section{Staffing}

1. In order to ensure equitable resourcing to support quality student learning across all South Australian schools, it is a priority that the School Library Association of South Australia (SLASA) work with education jurisdictions to develop frameworks for staffing relevant to the models of school library provision identified in this report, noting the following findings:

1.1. Small schools require additional assistance to achieve a viable level of library staffing and acceptable resource budget per student

1.2. Large schools with more than 1200 students currently employ significantly less library staff per student than other schools, raising questions about the quality of library service and resource management in these schools.

1.3. Special schools lack school library services. Library provision for special needs students must be improved to ensure equity of access for all South Australian students.

1.4. Joint-use libraries including school-community libraries, cross-sector school libraries, and senior secondary schools' agreements with university or TAFE libraries, deliver both benefits and challenges. These need to be quantified and used to inform decisions on new school development.

1.5. Mobile library services with visits on average fortnightly represent a suboptimal level of access for students compared to school-based library models. 
2. That education jurisdictions and employers in South Australia develop strategies and invest in raising the qualifications of those managing their school libraries.

2.1 Increase the number of schools managed by qualified teacher librarians by:

2.1.1 actively recruiting qualified teacher librarians to their schools

2.1.2 supporting teachers managing school libraries to gain librarianship qualifications 2.2 Increase the number of library-qualified support staff by:

2.2.1 supporting unqualified SSO/ESO working in libraries to gain a nationally recognised library training, for example, through TAFESA.

3. That South Australian education jurisdictions update their reporting requirements so that schools provide specific data on school library staffing and resourcing on a regular basis. This will allow stakeholders to identify trends in the provision of school libraries locally and facilitate policy decisions based on data.

\section{Management of school resources}

4. That the Department for Education note the dependence of South Australian schools on the Bookmark library management system, and the value it provides particularly to small, underresourced schools. Consider in particular, the cost-effectiveness of developing the system to support contemporary resource management, the risks associated with reliance on Bookmark, and the staff time and professional development overhead involved in implementing a new system across so many schools should this be required.

5. That for equitable access for all students, the South Australian government consider extending the online digital information resources available through the SA Public Library Network to be available across all South Australian schools.

\section{Key stakeholder perspectives}

6. That SLASA review the qualitative feedback from this census which reveals what school leadership value about school libraries, and use this to engage purposefully with leaders.

7. That SLASA highlight the curriculum resourcing and skills development that can be expertly delivered by a teacher librarian to reduce the load on teachers, and develop an informational campaign for teachers and school leadership teams.

\section{National benchmarking}

8. That school library associations around Australia work with education jurisdictions in states and territories to replicate this census and thus deliver the data recommended in the 2011 House of Representatives Inquiry. This will also allow South Australian jurisdictions to benchmark these findings against other states and territories. 


\section{GLOSSARY}

\begin{tabular}{|c|c|}
\hline Term & Meaning \\
\hline ACER & Australian Council for Educational Research \\
\hline AEU SA & Australian Education Union South Australian Branch \\
\hline ALIA & Australian Library and Information Association \\
\hline B-12 & Birth to Year 12 school \\
\hline BYOD & Bring Your Own Device \\
\hline CSL & Canadian School Libraries \\
\hline ESO & Education Support Officer \\
\hline ICSEA & Index of Community Socio-Educational Advantage \\
\hline Joint-use library & $\begin{array}{l}\text { A library managed jointly by more than one organisation or library sector, } \\
\text { for instance Department for Education and local council, or school and } \\
\text { university or TAFE }\end{array}$ \\
\hline Librarian & $\begin{array}{l}\text { A staff member holding a Bachelor or post-graduate qualification in } \\
\text { librarianship that is eligible for Associate membership of the Australian } \\
\text { Library and Information Association }{ }^{2}\end{array}$ \\
\hline Library & $\begin{array}{l}\text { A managed centre of resources, expertise and support services accessible to } \\
\text { the whole school community }\end{array}$ \\
\hline Library manager & Staff member responsible for managing a library \\
\hline Library technician & $\begin{array}{l}\text { A staff member holding a nationally accredited Diploma of Library and } \\
\text { Information Services }{ }^{3}\end{array}$ \\
\hline Library-qualified & $\begin{array}{l}\text { A staff member holding a qualification as teacher librarian, librarian or library } \\
\text { technician as recognised by the Australian Library and Information } \\
\text { Association }^{4}\end{array}$ \\
\hline Maker space & Communal work space set up for hands-on creative and technical activities \\
\hline $\begin{array}{l}\text { Multiple copy } \\
\text { collections }\end{array}$ & such as textbook loan service, reading schemes \\
\hline NAPLAN & National Assessment Program - Literacy and Numeracy \\
\hline $\mathrm{R}-12$ & Reception to Year 12 school \\
\hline
\end{tabular}

2 https://www.alia.org.au/librarians-and-information-specialists

3 https://www.alia.org.au/library-technicians

$4 \underline{\text { https://www.alia.org.au/lis-careers/accredited-courses-and-qualifications }}$ 


\begin{tabular}{|c|c|}
\hline Term & Meaning \\
\hline Reader advisory & Suggesting appropriate resources for staff and students \\
\hline Resource Centre & $\begin{array}{l}\text { A managed centre of resources, expertise and support services accessible to } \\
\text { the whole school community }\end{array}$ \\
\hline $\begin{array}{l}\text { School } \\
\text { Community } \\
\text { Library }\end{array}$ & $\begin{array}{l}\text { Shared library service funded by state education department and local } \\
\text { council to serve rural areas with a population of less than 5,000 residents. }\end{array}$ \\
\hline SEIFA & Socio-Economic Indexes for Areas \\
\hline SLASA & School Library Association of South Australia \\
\hline SSO & School Services Officer \\
\hline STEM & Science Technology Engineering and Mathematics \\
\hline Teacher librarian & $\begin{array}{l}\text { A registered teacher who also holds a professional qualification in } \\
\text { librarianship that is eligible for Associate membership of } A_{L I A}\end{array}$ \\
\hline Teacher-qualified & $\begin{array}{l}\text { Staff member with a teaching qualification who is eligible for registration as } \\
\text { a teacher }\end{array}$ \\
\hline TRB SA & Teacher Registration Board South Australia \\
\hline Virtual library & Curated collection of resources available online \\
\hline Wellbeing & Condition in which physical and/or psychological needs are satisfied \\
\hline
\end{tabular}

5 https://www.alia.org.au/teacher-librarians 


\section{REFERENCES}

ACT Education Directorate. (2019). School libraries: The heart of 21st century learning. https://www.education.act.gov.au/ data/assets/pdf file/0007/1435435/School-LibrariesThe-Heart-of-21st-Century-Learning.pdf

All Party Parliamentary Group for Libraries (APPGL). (2014). The beating heart of the school: Improving educational attainment through school libraries and librarians. CILIP. https://cdn.ymaws.com/www.cilip.org.uk/resource/resmgr/cilip new website/knowledge hubs/school libraries/beatingheartoftheschool.pdf

American Library Association (ALA). (2019). Highly effective school libraries have a common set of characteristics. American Library Association.

http://www.ala.org/tools/research/librariesmatter/highly-effective-school-libraries-havecommon-set-characteristics

Australian Curriculum, Assessment and Reporting Authority (ACARA). (2018). Australian Curriculum. https://www.australiancurriculum.edu.au

Australian Curriculum, Assessment and Reporting Authority (ACARA). (2019). National report on schooling in Australia 2017. https://www.acara.edu.au/reporting/national-report-onschooling-in-australia/national-report-on-schooling-in-australia-2017

Australian Education Union (AEU) SA Branch. (2013). School Library Staffing Policy. https://slasa.asn.au/Advocacy/docs/School Library Staffing_Policy_AEU 2013.pdf

Australian Institute for Teaching and School Leadership (AITSL). (2011). Australian Professional Standards for Teachers. https://www.aitsl.edu.au/docs/default-source/national-policyframework/australian-professional-standards-for-teachers.pdf

Australian Library and Information Association (ALIA). (2017). 10 ways that libraries power high performance schools. Australian Library and Information Association.

https://read.alia.org.au/10-ways-libraries-power-high-performance-schools-0

Australian Library and Information Association (ALIA). (2018). About libraries in Australia 2018. Australian Library and Information Association.

https://www.alia.org.au/sites/default/files/About\%20Australian\%20libraries\%202018.pdf

Australian School Library Association (ASLA), \& Australian Library and Information Association (ALIA). (2001). Learning for the future: Developing information services in schools. (2nd edition). Curriculum Corporation.

Australian School Library Association (ASLA). (2013). Future learning and school libraries. Australian School Library Association. https://asla.org.au/future-Learning-paper

Australian Schools Commission. (1979). Books \& beyond: Guidelines for library resource facilities and services (2nd edition). The Schools Commission.

Bundy, A. (2002). Essential connections: school and public libraries for lifelong learning. The Australian Library Journal, 51(1), 47-70. https://doi.org/10.1080/00049670.2002.10755976

Canadian School Libraries (CSL). (2018). Leading learning: Standards of practice for school library learning commons in Canada. http://Ilsop.canadianschoollibraries.ca

Canadian School Libraries (CSL). (2019). Excellent school libraries: Learning for the future.

http://www.canadianschoollibraries.ca/wp-

content/uploads/2018/03/CSL ExcellentSchoolLibraries.pdf 
Chu, W. (2013). Library exposure from the prior years: an examination of public high school library websites. The Journal of Academic Librarianship, 39(5), 392-400.

https://doi.org/10.1016/i.acalib.2013.03.003

Church, A. P. (2010). Secondary school principals' perceptions of the school librarian's instructional role. School Library Research, 13.

http://www.ala.org/aasl/sites/ala.org.aasl/files/content/aas/pubsandjournals/slr/vol13/SLR SecondarySchool V13.pdf

Clark, C., \& Teravainen, A. (2017). Celebrating reading for enjoyment: Findings from our Annual Literacy Survey 2016. National Literacy Trust. https://literacytrust.org.uk/documents/208/201706 01 free research celebrating reading enjoyment final 4uGtNrp.pdf

Combes, B. (2008). Australian School Libraries Research Project: A snapshot of Australian school libraries, Report 1. https://ro.ecu.edu.au/ecuworks/7115

Cunningham, K. S. (1961). The Australian Council for Educational Research and library services in Australia. Australian Council for Educational Research.

Curtis, N. (2017). The role of leadership in the 'Ongoing importance of school libraries'. Access, 31(3), 42-47.

Department for Education. (2019). School resource entitlement statement, Supporting information. Government of South Australian.

https://www.education.sa.gov.au/sites/default/files/school res notes 2019.pdf

Department of Education and Training. (2018). Through growth to achievement: The report of the review to achieve educational excellence in Australian schools. Australian Government. https://docs.education.gov.au/node/50516

Dow, M. J. \& McMahon-Lakin, J. (2012). School librarian staffing levels and student achievement as represented in 2006-2009 Kansas annual yearly progress data. School Library Research, 15.

Evidence for Learning (2020). About the Toolkit: Months' impact. https://evidenceforlearning.org.au/the-toolkits/about/\#months-impact

Fenwick, S. I. (1966). School and children's libraries in Australia: a report to the Children's Libraries Section of the Library Association of Australia. FW Cheshire for the Library Association of Australia.

Francis, B. H., Lance, K. C. \& Lietzau, Z. (2010). School librarians continue to help students achieve standards: The Third Colorado Study (2010). A Closer Look. https://www.Irs.org/documents/closer_look/CO3 2010 Closer_Look_Report.pdf

Gavigan, K. \& Lance, K. C. (2015). Everybody's teacher: Administrators' and teachers' perceptions of school librarians. Findings from the South Carolina Association of School Librarians Impact Study. Teacher Librarian, 43(1), 8-11.

Godfree, H. \& Neilson, O. (2018). School libraries matter! The missing piece in the education puzzle. Access, 32(1), 28-40.

https://asla.org.au/resources/Documents/Website\%20Documents/Advocacy/school librari es matter.pdf 
Gonski, D., Boston, K., Greiner, K., Lawrence, C., Scales, B., \& Tannock, P. (2011). Review of funding for schooling. Final report.

https://docs.education.gov.au/system/files/doc/other/review-of-funding-for-schoolingfinal-report-dec-2011.pdf

Gordon, C. A. (2015). What makes a school library good? An action research casebook study. Synergy, 13(2). https://slav.vic.edu.au/index.php/Synergy/article/view/V1321512

Hartzell, G. (2002a). The principal's perceptions of school libraries and teacher librarians. School Libraries Worldwide, 8, 92-110.

Hartzell, G. (2002b). Why should principals support school libraries? ERIC Digest. https://files.eric.ed.gov/fulltext/ED470034.pdf

Hay, L. (2005). Student learning through Australian school libraries Part 1: A statistical analysis of student perceptions. Synergy, 3(2), 17-30.

Hay, L. \& Todd, R. J. (2010). School libraries 21C. School Libraries and Information Literacy Unit, Curriculum K-12 Directorate, NSW Department of Education and Training.

Herring, J. (2007). Teacher librarians and the school library. In S. Ferguson (Ed.), Libraries in the Twenty-First Century: Charting Directions in Information Services (pp. 27-42).

Holland, B. (2015). 21st-century libraries: the learning commons. Edutopia, Jan, 14. https://www.edutopia.org/blog/21st-century-libraries-learning-commons-beth-holland

House of Representatives Standing Committee on Education and Employment. (2011). School libraries and teacher librarians in 21st century Australia. Commonwealth of Australia. http://www.aph.gov.au/Parliamentary Business/Committees/House of Representatives Committees? url = ee/schoollibraries/report.htm

Hughes, H. E. (2013a). School libraries, teacher librarians and their contribution to student literacy development in Gold Coast schools. https://eprints.qut.edu.au/60260/38/60260b.pdf

Hughes, H. E. (2013b). School libraries and teacher librarians: evidence of their contribution to student literacy and learning. Curriculum and Leadership Journal, 11(12).

Hughes, H. E., Leigh, T., Osborne, M., Fraser, S., Kahl, C. \& Reynolds, H. (2013). School libraries, teacher librarians and literacy at Gold coast schools: Research findings. Synergy, 11(2).

Hughes, H., Bozorgian, H. \& Allan, C. (2014.) School libraries, teacher librarians and student outcomes: Presenting and using the evidence. School Libraries Worldwide, 20(1), 29-50.

International Federation of Library Associations and Institutions (IFLA). (2015). IFLA school library guidelines. $2^{\text {nd }}$ edition. https://www.ifla.org/files/assets/school-libraries-resourcecenters/publications/ifla-school-library-guidelines.pdf

Killoran, P. (2018). Ladies and gentlemen the school library has left the building. An Investigation into school libraries, their efficacy, successes and dilemmas. Doctoral dissertation. City University London. https://doi.org/10.17613/rbyw-8337

Kirby, F. (1945). Libraries in secondary schools: A Report on the Libraries of Secondary Schools in Victoria, with suggestions for a post-war plan for school libraries prepared for the Australian Institute of Librarians (Victorian Branch). Melbourne University Press. https://research.acer.edu.au/information management/7

Kuon, T., Flores, J. \& Pickett, J. (2014). The biggest classroom in the building. Phi Delta Kappan, 95(7), 65-67. https://doi.org/10.1177/003172171409500715

Lance, K. C. \& Hofschire, L. (2012). Change in school librarian staffing linked with change in CSAP reading performance, 2005 to 2011. A closer look. Library Research Service. 
Lance, K. C. \& Kachel, D. E. (2018). Why school librarians matter: What years of research tell us. Phi Delta Kappan, 99(7), 15-20.

Lance, K. C., Rodney, M. J. \& Russell, B. (2007). How students, teachers and principals benefit from strong school libraries. Association for Indiana Media Educators.

https://cdn.ymaws.com/www.ilfonline.org/resource/resmgr/aisle/infinalreportnextsteps.pdf

Libraries Board of South Australia (2019). 2018-19 Annual Report. https://www.slsa.sa.gov.au/ sites/default/files/2019-10/Libraries-board-annual-report-2018-19.pdf

Loh, C. E., Ellis, M., Paculdar, A. A., \& Wan, Z. H. (2017). Building a successful reading culture through the school library: A case study of a Singapore secondary school. IFLA Journal, 43(4), 335-347. https://doi.org/10.1177/0340035217732069

Lonsdale, M. (2003). Impact of school libraries on student achievement: A review of the research. https://research.acer.edu.au/tll misc/23

Lupton, M. (2013). Inquiry pedagogy and the Australian Curriculum. Primary and Middle Years Educator, 11(2), 23-29.

Lupton, M. (2016). Adding value: Principals' perceptions of the role of the teacher librarian. School Libraries Worldwide, 22(1), 49-61.

Mangen, A. \& van der Weel, A. (2016). The evolution of reading in the age of digitisation: An integrative framework for reading research. Literacy, 50(3), 116-124.

https://doi.org/10.1111/lit.12086

Merga, M. K. (2018). Do librarians feel that their profession is valued in contemporary schools? Journal of the Australian Library and Information Association, 1-20.

Merga, M. K. (2019). How do librarians in schools support struggling readers? English in Education, 1-16.

Merga, M. K. \& Gardiner, V. (2018). The role of whole-school literacy policies supporting reading engagement in Australian schools. English in Australia, 53 (3), 37.

Mitchell, P. (2011). Resourcing 21st century online Australian Curriculum: The role of school libraries. FYI, Autumn, 10-15. https://search.informit.com.au/fullText;dn=188987; res=AEIPT

Mitchell, P. (2018). How does your collection measure up? Using the school collection rubric. FYI: The Journal for the School Information Professional, 22(2), 18-21.

Mitchell, P. \& Weldon, P. (2016, August). The school library workforce in Australia. In Australian Library and Information Association National 2016 Conference, Adelaide. https://works.bepress.com/pru mitchell/26

Montiel-Overall, P. \& Grimes, K. (2013). Teachers and librarians collaborating on inquiry-based science instruction: A longitudinal study. Library \& Information Science Research, 35(1), 41-53.

Munn, R. \& Pitt, E.R. (1935). Australian libraries: A survey of conditions and suggestions for their improvement. Australian Council for Educational Research.

Ofsted (2006). Good school libraries: making a difference. London, Ofsted. https://dera.ioe.ac.uk/5792/1/Good\%20school\%20libraries\%20making\%20a\%20difference \%20to\%20learning\%20(PDF\%20format).pdf

Pennsylvania School Library Project (Pennsylvania School Librarians Association, Health Sciences Library Consortium and Education Law Center of Pennsylvania) (2012). Creating 21st-century learners: A report on Pennsy/vania's public school libraries. https://www.elc-pa.org/wpcontent/uploads/2015/02/Creating21stCenturyLearners LibraryDataReport.10.17.12.pdf

Ryan, S. (2018). School libraries in Australia: Reflections on ALIA's role over the past 50 years. Journal of the Australian Library and Information Association, 67(2), 155-163. 
Scholastic. (2008). School libraries work! $3^{\text {rd }}$ ed.

https://scholasticlibrary.digital.scholastic.com/media/wysiwyg/PDF/SLW3.pdf

Scholastic. (2016). School libraries work! A compendium of research supporting the effectiveness of school libraries. http://www.scholastic.com/SLW2016

Shannon, D. (2009). Principals' perceptions of school librarians. School Libraries Worldwide, 15(2), 1.

Shaper, S. (Ed.). (2014). CILIP Guidelines for Secondary School Libraries. Facet Publishing.

Shaper, S. \& Streatfield, D. (2012). Invisible care? The role of librarians in caring for the 'whole pupil' in secondary schools. Pastoral Care in Education, 30(1), 65-75. https://doi.org/10.1080/02643944.2011.651225

Softlink. (2010). Submission for the Inquiry into school libraries and teacher librarians in Australian schools. Submission 255, pp. 1-20.

https://www.aph.gov.au/parliamentary business/committees/house of representatives committees?url=ee/schoollibraries/subs/sub255.pdf

Softlink. (2012). Australian school library survey 2012. Softlink International.

Softlink. (2016). Softlink Australian School Library Survey: A five-year review. Access, 30(2), 26-

32. https://search.informit.com.au/documentSummary; $d n=134081305399604 ;$ res=IELHSS

Softlink. (2017). The 2016 Softlink Australian and New Zealand school library survey.

https://www.softlinkint.com/downloads/Australian_and_New_Zealand School library sur vey report.pdf

Softlink. (2018). The 2017 Softlink Australian and New Zealand school library survey. https://www.softlinkint.com/downloads/2017 Softlink Australian and New Zealand Sch ool Library Survey Report.pdf

Softlink. (2019). The 2018 Softlink Australian, New Zealand and Asia-Pacific school library survey report.

https://www.softlinkint.com/downloads/2018 Softlink_Australian_and New Zealand Sch ool Library Survey Report.pdf

Softlink. (2020). The 2019 Softlink Australian, New Zealand and Asia-Pacific school library survey report.

https://www.softlinkint.com/downloads/2019 APAC School Library Survey Report.pdf

Swain, H. (2015). School libraries shelve tradition to create new learning spaces. The Guardian. https://www.theguardian.com/teacher-network/2015/ian/08/school-libraries-booksstudents-technology

Taddeo, C., \& Barnes, A. (2016). The school website: Facilitating communication engagement and learning. British Journal of Educational Technology, 47(2), 421-436.

Tait, E., Vo-Tran, H., Mercieca, P. \& Reynolds, S. (2019). Don't worry, a school library with fewer books and more technology is good for today's students. The Conversation, April 2019. https://theconversation.com/dont-worry-a-school-library-with-fewer-books-and-moretechnology-is-good-for-todays-students-114356

Thomson, S. \& Hillman, K. (2019). The Teaching and Learning International Survey 2018. Australian Report Volume 1: Teachers and School Leaders as Lifelong Learners. Australian Council for Educational Research, Melbourne. https://research.acer.edu.au/talis/6

Thomson, S., Hillman, K. \& De Bortoli, L. (2013). A teacher's guide to PISA reading literacy. Australian Council for Educational Research, Melbourne.

https://research.acer.edu.au/ozpisa/11 
Todd, R. J. (2015). Evidence-Based Practice and School Libraries: Interconnections of Evidence, Advocacy, and Actions. Knowledge Quest, 43(3), 8-15.

Todd, R. J. \& Kuhlthau, C. C. (2004). Student learning through Ohio school libraries. OELMA.

Todd, R. J. \& Kuhlthau, C. C. (2005). Student learning through Ohio school libraries, Part 1: How effective school libraries help students. School Libraries Worldwide, 11(1), 63-88.

Todd, R. J., Kuhlthau, C. C., \& OELMA. (2004). Model of the school library as a dynamic agent of learning. Student Learning through Ohio School Libraries: The Ohio Research Study. Columbus, $\mathrm{OH}$ : Ohio Educational Library Media Association.

Todd, R. J., Gordon, C. \& Lu, Y. (2011). Report on Findings and Recommendations of the New Jersey School Library Study Phase 1: One Common Goal: Student Learning. CISSL.

Trask, M. (1968). School libraries: A report to the nation. Cheshire for the Australian Library Week Council.

Weldon, P. R. (2016). What the Staff in Australia's Schools surveys tell us about teachers working in school libraries. ACER, Melbourne. https://research.acer.edu.au/tll misc/25

Williams, T. (2020). A sense of community. The Messenger, Adelaide, 5 February 2020.

Wimolsittichai, N. (2017). School libraries and their roles in rural Thailand: Perceptions of public primary school principals [thesis], Queensland University of Technology.

https://eprints.qut.edu.au/116146 


\section{APPENDIX A: SURVEY METHODS}

In late 2018, a working group of researchers from ACER and librarians from SLASA came together to design a survey that would gather pertinent information from schools on the status of their libraries, keeping in mind the key factors for effective school libraries discussed previously. The items were designed to be answerable by any member of staff on the school leadership team, not the teacher librarian specifically. In order to further minimise non-response bias, the survey title included 'library and information', so as not to put-off schools that no longer have a physical library space.

The development of the survey was undertaken during the review of literature, in order to first identify previous school library surveys from which an item-bank could be established. Almost 100 relevant items were extracted from the 10 identified sources listed below, most of which were of previous informal surveys conducted in the ACT and Queensland. No Australian school library surveys or questionnaires were identified that had been conducted using formal research protocols (e.g. sought ethics approval).

- ACT2012: ACT 2012 Teacher librarian Survey Questions

- ACT2014: ACT Government Schools Library Staffing Survey

- ACT2016: 2016 Library Staffing

- ACT2017: 2017 Staffing Survey of ACT Primary School Libraries

- ACT2018: 2018 Staffing Survey of ACT Primary and Secondary School Libraries

- QSLA2018a: Status of teacher librarians and school libraries in Queensland schools (May 2018 Draft)

- QSLA2018b: Status of teacher librarians and school libraries in Queensland schools (Nov 2018 Online)

- THAI2017 Wimolsittichai PhD: Appendix C: The Survey Regarding the public primary school library, and its role and the impact of the library on students' academic achievement in rural Thailand.

- CAN2014 Survey Questionnaire for School Librarians

- SOFT2017 Softlink Australian and New Zealand School Library Survey Report 2017.

The items sourced from previous library survey questions were organised by the conceptual domains that emerged. These conceptual domains formed the measurement framework presented in Table 5, which guided the development of the survey. There were many similar items in common across the surveys, resulting in an item short-list of 32 consolidated items. These short-listed items formed the starting point of the present survey, and broadly addressed the conceptual domains of background, context, staffing, services, and funding. 
Table 5. School library measurement framework

\begin{tabular}{|c|c|}
\hline Domain & Indicators \\
\hline $\begin{array}{l}\text { School } \\
\text { background }\end{array}$ & $\begin{array}{l}\text { - School type, sector, location, size, SES } \\
\text { all influence the quality of students the school attracts, which in turn affects } \\
\text { funding }\end{array}$ \\
\hline Funding & $\begin{array}{l}\text { - Funding (e.g. school budget allocations, voluntary contributions, donations, } \\
\text { fundraising) }\end{array}$ \\
\hline $\begin{array}{l}\text { Facilities, } \\
\text { collections \& } \\
\text { access }\end{array}$ & $\begin{array}{l}\text { - Physical and virtual space } \\
\text { - Collections and resources } \\
\text { - Technology and equipment }\end{array}$ \\
\hline Services & - Services provided (e.g. a safe place, special events, central learning hub) \\
\hline Staffing & $\begin{array}{l}\text { - Number of full-time/part time library staff } \\
\text { - } \text { Qualifications and experience } \\
\text { - Library and information management }\end{array}$ \\
\hline $\begin{array}{l}\text { Curriculum \& } \\
\text { teaching }\end{array}$ & $\begin{array}{l}\text { - Curriculum serviced by the library (e.g. cyber-safety) } \\
\text { - Supportive services (e.g. release time, professional learning) }\end{array}$ \\
\hline Quality & $\begin{array}{l}\text { - Supported by leadership } \\
\text { - Effectively managed, staffed, funded, resourced } \\
\text { - Valued by community } \\
\text { - Contributing to improved student outcomes }\end{array}$ \\
\hline
\end{tabular}

A focus-group was conducted in late December 2018 to work through the item short-list and refine the form and focus of the survey. The expert group was comprised of three South Australian teacher librarians, the SLASA President, and the Manager of the ACER Cunningham Library. Participants were provided with the short-list of items and a guided discussion captured their views about each survey item. To prompt discussion and feedback from participants, the following types of questions, worded appropriately for their age group, were asked:

- Were there any confusing or inconsistent terms or questions?

- Were there any overly difficult or overly time-consuming questions?

- Were response categories inappropriate (i.e. not mutually exclusive, not applicable, or not covering all relevant situations)?

- Were any questions or items irrelevant to you personally?

- Were there any questions that made you feel uncomfortable (e.g. sensitive issues or concerns regarding the confidentiality/privacy of information)?

- Do you have suggestions for ways to reword any items to make them clearer?

Importantly, the resulting survey had to use plain English and terminology that any member of school staff could interpret. Where possible, open-text items were converted to multiple-choice and complex items, particularly those regarding number of FTE hours, were avoided. Participants were also reminded that the survey was more likely to be completed by a non-teacher librarian, also limiting items to what might be general school knowledge, rather than library-specific 
knowledge. They had no problem with understanding the intent of the items or the scales used, and participants were not concerned about the subject area or the questions being asked.

\section{Ethics}

Prior to census administration, ethics applications were submitted and approved by the ACER Ethics Committee (9 November 2018, Ref no. 325), Catholic Education (4 June 2019 and Ref no. 201920), as well as the Department for Education (24 July 2019 and Ref no. 2019-7407609).

ACER used the Australian PeoplePulse online platform for survey administration. ACER staff adhered to and compiled with the Australian Information Privacy Act 1988 in accordance with the Australian Government Department of Education and Training privacy requirements for data stored and used in Australia.

\section{Census administration}

The SA Library Census was administered online during Term 3 2019. On the 26 July 2019 the initial invitation to participate in the census was sent to 728 South Australian government and independent schools (including schools with more than two campuses). The inital invitation was addressed to the school principal and sent to the schools generic email address. The principal was asked to complete the census using the provided link or to forward the email invite to a nominee such as the school Librarian. Data collection was online and could be accessed through mainstream mobile-friendly mediums, such as tablets and smart phones and Desktop computers.

\section{Survey reminders and administration tasks}

Participation rates were monitored regularly and several email reminders to complete the census were sent to principals or to their nominated staff members during the administration period. In addition, ACER provided SLASA with regular updates regarding school participation. SLASA also promoted the census by distributing the survey link within their membership groups during the administration period - SLASAnet (an email discussion list for SA library staff www.slasa.asn.au/ Networks/onlinecomm.html) and OZTLnet (Australian Teacher Librarian Network oztlnet.com). Book week, a particularly busy time for librarians, fell in the middle of survey administration period, so reminders were paused.

\section{Call centre follow-up and achieving census}

In addition to sending reminders, ACER established a dedicated call center to communicate directly with schools via telephone and email. Beginning on August 26, call centre staff focussed on contacting schools that had not started their census. Schools were telephoned directly to remind them to complete the census or if the school had not received the invite to re-send any missed emails.

Direct telephone contact with schools was invaluable as it provided an opportunity to clarify the appropriate school staff to contact to complete the census and also afforded the opportunity to explain the project and gain the school's support. The call centre operated until 12 September prior to the close of the census. 
In order to achieve a census of South Australian schools, any school that had declined or had not yet responded to reminder emails were telephoned and asked by call centre staff to answer two questions:

Which of the following best describes the library service at your school?

- A central library or resource centre within the school

- A jointly managed school-community and public library

- A local community public library or mobile service (i.e. no on-site library)

- A virtual library of school-managed online collections and resources (e.g. databases, e-books)

Approximately how much dedicated space does your school have on-site for library activities and resources?

- About 3 or more standard classrooms

- About 2 standard classrooms

- About 1 standard classroom

- Less than 1 standard classroom

- No dedicated space on campus

These two questions, which are aligned with questions asked in the survey, enabled information about the nature and size of library services of every South Australian school and applicable campus to be captured and represented in analysis and reporting. Table 6 presents a summary of the administrative efforts to achieve census.

Table 6. Survey invites and reminders

\begin{tabular}{|c|c|c|}
\hline Month & Date & Census Administration tasks \\
\hline July & 26 & Census open and initial invites sent (728) \\
\hline \multirow[t]{6}{*}{ August } & 2 & Reminders sent (635) \\
\hline & 8 & Reminders sent (486) \\
\hline & \multicolumn{2}{|r|}{ Book Week 17-23 August (no contact) } \\
\hline & 23 & Reminders sent (375) \\
\hline & 26 & Call Centre commenced \\
\hline & 30 & Reminders sent (298) \\
\hline \multirow[t]{4}{*}{ September } & 4 & Reminders sent (256) \\
\hline & 6 & Reminders sent (149) \\
\hline & 12 & Reminders sent (119) \\
\hline & 13 & Census closed \\
\hline
\end{tabular}




\section{Approach to analysis}

Once the census data collection period had closed the data was downloaded from the PeoplePulse online platform and stored securely. This excel data file was matched to the target list of all schools in South Australia. This list also included school demographic characteristics. It was also used by the call centre to record response to the two questions, along with the website review. The data merge achieved census, resulting in a complete database about the nature and size of library services of every South Australian school and applicable campus. In order to achieve one record per school the data was prepared in such a way that the small number of schools with more than one response were combined per school, with views provided by library staff given preference where discrepancies occurred. Most of the occasions where schools had multiple responses were when both the principal and library staff had responded. Other data cleaning that took place involved the removal of duplicates where a census survey had accidentally been submitted twice, and the removal of empty census surveys where a response had been submitted with no data.

Analysis was performed through basic frequency counts and combining data from more than one question to form a new variable of interest. This enabled multivariate analysis and allowed the team to look for associations between different variables. Where associations are reported these are for statistically significant relationships measured using likelihood ratio chi-square tests, with significance level set at 0.05 or below. Frequencies are reported as percentages of the whole census, unless the variable of interest is a sub-question, for example, when asked about the background and fraction of time funded for the library manager these are reported as percentages of the number of responses answering yes to whether the school currently has someone to manage a library collection. Where responders could choose more than one answer these percentages will total more than 100 due to multiple choices per responder.

Open-ended questions were analysed using thematic analyses where common themes are coded across all responses. The percentage reported for these themes is the percentage of the whole census. Often these percentages will total more than $100 \%$ as one response could be coded to more than one theme. 


\section{APPENDIX B: THE SCHOOL LIBRARY SURVEY}

\section{School Library and Information Census}

Very little is known about the profile of school library and information services in Australia. ACER is conducting a census approach, starting in South Australia, to gather high-level data from school leadership to better understand the changing face of how schools are managing information and literacy resources and programs.

Please tell us about your school's context and current approaches to supporting teachers in resourcing the curriculum, and building students' literacy and information literacy.

To give an accurate picture, we encourage you to consult with your most knowledgeable staff in this area.

if Note that the survey 'save' button lets you stop part way through and continue later by sending you a direct link.

All responses are anonymous and only summarised results will be reported. Thank you.

- Definitions for the purpose of this survey are informed by the Australian Library and Information Association (ALIA)

- 'Library' or resource centre is used to refer to a managed centre of resources, expertise and support services accessible to the whole school community.

- 'Teacher Librarian' refers to a registered teacher who also holds a professional qualification in librarianship that is eligible for Associate membership of ALIA

- 'Librarian' refers to a staff member holding a Bachelor or post-graduate qualification in librarianship that is eligible for Associate membership of ALIA.

- 'Library Technician' refers to a staff member holding a Diploma of Library and Information Services.

- 'SSO/ESO' refers to school support staff.

All information that is collected in this study will be treated confidentially. While summary results will be made available to the School Library Association of SA (SLASA), the SA Department for Education, Catholic Education SA, and Association of independent Schools SA, you are guaranteed that neither you, this school, nor any school personnel will be identified in any reporting of results. All data collected are kept strictly confidential as defined in the Privacy Act 1988 (Cth). You may also view ACER's Privacy Policy at https://www acer.org/privacy.

If you wish to withdraw your school from this survey, please select your school and the option 'The school is declining to participate; on the next screen. If you wish to preview the survey click here (your responses will not be recorded).

* Please enter and select your school:

* Who is answering this survey? Please select your role or position in the school.

Please select all that apply

ГPrincipal, including Acting or Deputy

Г Library staff

ГSchool administration staff

ГTeacher

Г Other: please explain

None: The school is declining to participate (click Next to exit the survey) 


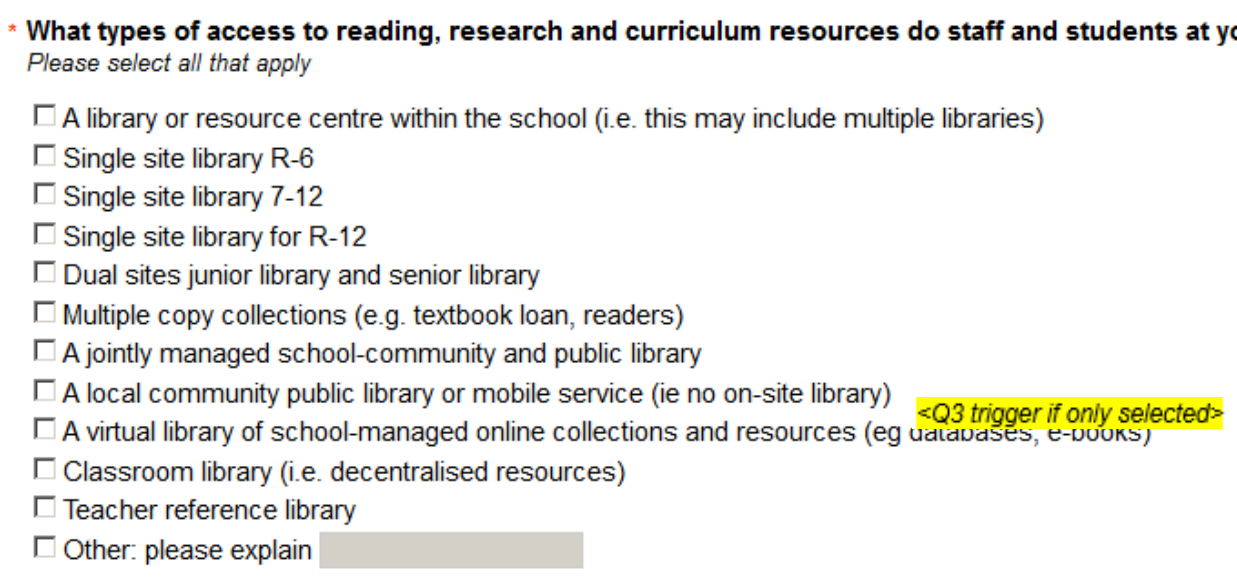

Approximately how much dedicated space does your school have on-site for library activities and resources? A 'standard classroom' is taken as the size to accommodate up to 30 students. Please select one

Equivalent to three or more standard classrooms

Equivalent to two standard classrooms

Equivalent to one standard classroom

Cquivalent to less than one standard classroom

No dedicated space on campus

Has the library space been encroached upon and repurposed recently? If so, is this a temporary or permanent change?
No
Yes, temporary (please explain)
$\checkmark$ Yes, permanent (please explain)

Which of the following resources does your school provide for staff and students? chide if Q3 no library >

Please select all that apply

Physical resources in dedicated spaces (excludes classrooms)

<hide if Q3 no library >

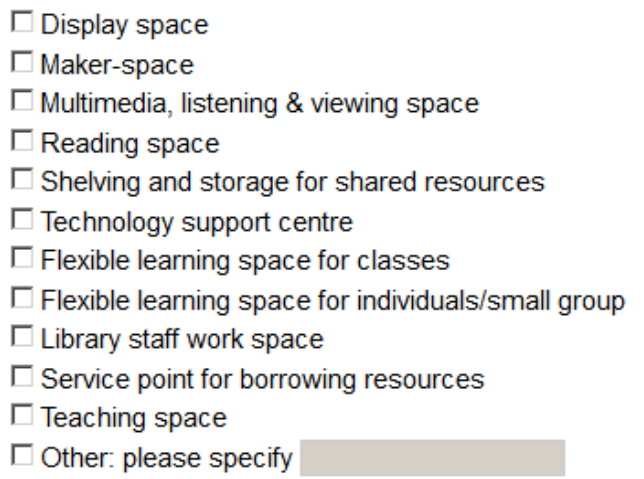

\section{Networked resources}

$\square$ All or most students BYOD (bring your own device) as per school policy

ГDesktop computers in classrooms for student use

ГDesktop computers in classrooms for staff use

ГDesktop computers in labs/library

$\Gamma$ Laptops, tablets or other portable digital device

E-book readers (e.g. Kindle)

ГOther: please specify 
$\square$ Managing specialist program/s across the school (e.g. literacy, STEM, coding, makerspace)

$\square$ Selecting and purchasing relevant, quality learning resources on behalf of the school

$\Gamma$ A safe place for students

$\square$ Managing access to the school's resource collection (e.g. including multi-media)

$\ulcorner$ Special events (e.g. Book Week, book fairs)

$\ulcorner$ Curriculum resource support to teachers

$\ulcorner$ A central learning hub for the school

$\ulcorner$ Developing a love of reading through reading programs that teach and assess reading skills

$\square$ Teaching research/inquiry skills, information and digital literacy to students

$\ulcorner$ Collaborative planning and instruction of learning and assessment

$\ulcorner$ Other: please explain

What library and learning resource management systems does your school use?

\author{
Library management systems \\ $\Gamma$ None \\ $\ulcorner$ Access-it \\ $\Gamma$ Amlib \\ $\ulcorner$ Bookmark \\ $\Gamma$ Destiny \\ $\ulcorner$ Infiniti \\ $\ulcorner$ Koha \\ ᄃ OCLC Worldshare \\ $\ulcorner$ Oliver \\ $\ulcorner$ SmartSuite (Functional Solutions) \\ $\ulcorner$ Symphony \\ $\Gamma$ Spydus \\ $\ulcorner$ Other: please specify
}

\author{
Learning resource services \\ $\ulcorner$ None \\ $\ulcorner$ Apps management \\ $\Gamma$ Audiobook platforms (e.g. Bolinda) \\ $\ulcorner$ Digital magazines (e.g. rb digital) \\ $\Gamma$ Digital video platforms (e.g. ClickView, EnhanceTV) \\ $\lceil$ Digital textbook services (e.g. Learning Fields) \\ $\ulcorner$ Ebook platforms (e.g. Overdrive, Wheelers) \\ $\ulcorner$ Subscription databases (e.g. Ebsco) \\ $\sqsubset$ Website curation (e.g. Libguides, LinksPlus) \\ $\ulcorner$ Library website \\ $\Gamma$ Library presence on social media \\ $\ulcorner$ Other. please specify
}

Please briefly tell us about your library or how your school provides for library-type information, activities and resources.

e.g. How is it referred to; interesting features or uses?

\footnotetext{
* Does your school currently have someone to manage the library collection and select resources?

This would be the person who takes main responsibility for managing library-type services in your school.

Please select one
No
$<Q 9$ trigger
Yes 


\section{What is their background?}

Please select one

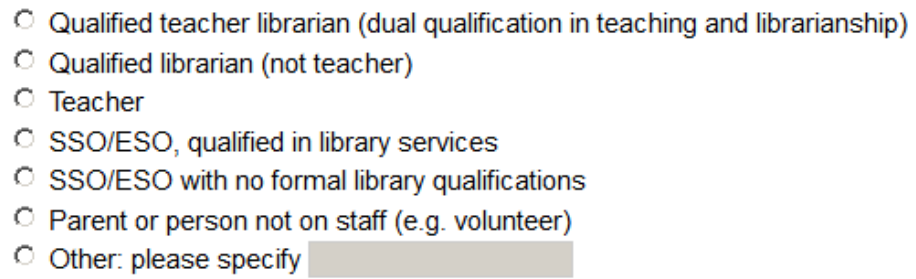

\section{What fraction of time is he/she funded to manage the library?}

Please select one

1.0 Full time equivalent (FTE)

0.8-0.9 FTE

0.6-0.7 FTE

O $0.4-0.5 \mathrm{FTE}$

$0.2-0.3 \mathrm{FTE}$

Less than $0.2 \mathrm{FTE}$

Volunteer or not funded

Other: please explain

\section{How is your school library staffed (either funded or voluntary)?}

\section{Qualified teacher librarian}

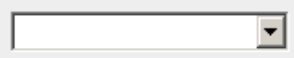

Teacher

Library-qualified SSO/ESO (librarian, library technician)

SSO/ESO with no formal library qualifications

Parents or person not on staff

Other
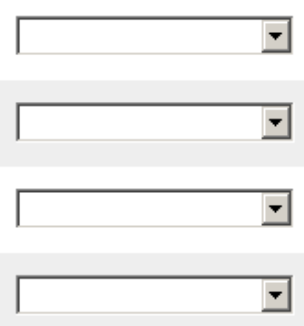

What supporting activities occur as part of the library services in your school?

Please select all that apply

$\sqsubset$ Release time for other teachers

$\square$ Flexibly timetabled lessons with library staff as required

$\ulcorner$ Collaborative planning with teachers

$\ulcorner$ Professional learning for staff

$\sqsubset$ Online teaching

$\square$ Reader advisory service (helping students to find their next book)

$\square$ One-on-one support according to student requests

$\ulcorner$ Small group support for students

$\ulcorner$ Class group teaching outside the library

$\ulcorner$ Supporting action research

$\ulcorner$ Collaborative assessment development

$\sqsubset$ Other teaching: please explain 
If any of the following are priorities in your school's curriculum, who mainly plans or supervises them?

\section{Main person}

Please select one answer for each priority

Cyber-safety and digital wellbeing

Literacy and reading program (e.g. Sustained

reading, Wide reading)

Information and digital literacy

Research, study skills, inquiry learning

Referencing skills

Digital technologies/STEM

Copyright/Creative Commons and ethical use of information

Enrichment learning (e.g. competitions, clubs)
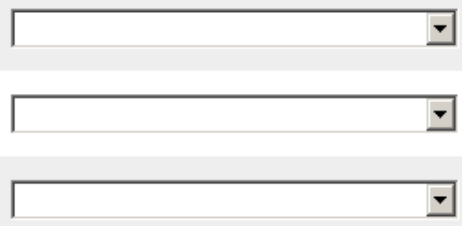

How is the school library funded?

<hide if Q3 no library >

Please select all that apply

$\ulcorner$ Allocated funds from school budget

$\ulcorner$ Voluntary contributions paid by parents or donated

Г Fundraising

$\sqsubset$ Other: please explain

Approximately how much of the school's recurrent budget is allocated to supporting and resourcing the library, not including staff salaries and facilities?

<hide if Q3 no library >

Please select one

Less than $\$ 1,000$

o $\$ 1,001-\$ 2,500$

○ $\$ 2,501-\$ 5,000$

o $\$ 5,001-\$ 7,500$

- $\$ 7,501-\$ 10,000$

C $\$ 10,001-\$ 20,000$

o $\$ 20,001-\$ 30,000$

C $\$ 30,001-\$ 40,000$

○ $\$ 40,001-\$ 50,000$

Greater than $\$ 50,000$

Has the school's recurrent budget changed from the previous year?

chide if Q3 no library > Please select one

Library budget increased: why?

Library budget did not change: why?

Library budget decreased: why? 
Please rate your library and information services, overall, in terms of the following.

Please select one choice in each row

Supported and backed by school leadership
Effectively managed
Effectively staffed
Effectively funded
Well-resourced and current
Valued by the school community
Contributing effectively to student learning
Providing resources equitably across the school community

What is the best thing about how your school provides for library and information services?

What are the current challenges in providing library and information services to your school community? 


\section{APPENDIX C: SCHOOL WEBSITE REVIEW PROTOCOL}

In their review of 30 South Australian school websites, Taddeo and Barnes (2016) defined the school website as "an environment, which aligns with the school culture, mission and goals to: enable and enhance teaching, learning, communication and innovation; connect and engage communities by facilitating the exchange of information, ideas and resources; support the organisational and functional operations of a school" (p. 421).

There was no mention of the library in the discussion about 'progressive websites' having links to content such as "sporting events", "current news", "ICT" and "school policies and curriculum statement" (Taddeo \& Barnes, 2016, p. 427). This suggest that libraries may not be a general feature of websites.

With little guidance from the literature, an initial exhaustive search through 20 randomly selected school websites was conducted independently by two researchers to determine the existence of a library, resource centre, or equivalent. Notes were compared to confirm terminology (eg. library, resource centre), the likely places it might appear (eg. menu link, context statement, newsletter, map), to rank the level of visibility of the evidence, and determine an adequate length of time to search a site.

The following standardised search protocol was developed and managed in a spreadsheet so that every school website was given the same treatment. Three other researchers were trained to use the protocol to screen all school websites, including the original 20 test sites. Where available, evidence in artefacts accessed from the school website (for example, school campus map) were systematically saved with the potential for further qualitative analysis. The Search Protocol parameters and data collection included:

- Time searching: 5 minutes per site.

- Initial Google search statement: library site:<school website address> or use site search facility if available.

- Evidence of library on school grounds map, if available.

- Photos of library, if available.

- Source status - Reviewers systematically worked through the following hierarchy of evidence until the appropriate category level was found and scored accordingly:

1. Dedicated webpage (link)

2. Webpage subsection (link but not library-specific)

3. Webpage miscellaneous mention

4. School/parent/student handbook

5. Context statement/improvement plan

6. No evidence found

7. Does not have

- Source description: This supporting evidence may include terms like 'handbook', 'newsletter' or a direct web link.

- Library name - how is it referred to, if available?

- Library description - how is it described, if available, to gain a perspective on the perceived importance of the school library (ie. is it the heart of the school or mentioned as an afterthought)? 


\section{APPENDIX D: AEU SA BRANCH POLICY SCHOOL LIBRARY STAFFING}

Peak enrolment figures (i.e. October estimates in primary and February estimates in secondary) are used to determine the library allocation time. Teacher librarians are expected to contribute to instruction time as indicated.

\begin{tabular}{|l|c|c||c|c|}
\hline $\begin{array}{l}\text { Enrolment } \\
\text { Estimate }\end{array}$ & $\begin{array}{c}\text { Number of } \\
\text { Teacher librarians }\end{array}$ & $\begin{array}{c}\text { Contribution to } \\
\text { Instruction Time }\end{array}$ & $\begin{array}{c}\text { Number of } \\
\text { Teacher librarians }\end{array}$ & $\begin{array}{c}\text { Contribution to } \\
\text { Instruction Time }\end{array}$ \\
\hline Less than 61 & 0.1 & 0.0 & \multicolumn{2}{|c|}{ Secondary schools } \\
\hline $61-96$ & 0.2 & 0.0 & & \\
\hline $97-135$ & 0.3 & 0.0 & & \\
\hline $136-210$ & 0.4 & 0.0 & & \\
\hline $211-285$ & 0.6 & 0.0 & & \\
\hline $286-360$ & 0.8 & 0.0 & 1.0 & 0.25 \\
\hline $361-499$ & 1.0 & 0.0 & & \\
\hline $500-649$ & 1.5 & 0.3 & & \\
\hline $650-799$ & 2.0 & 0.4 & 2.0 & 0.375 \\
\hline $700-1000$ & & & & \\
\hline 800 or greater & 2.5 & 0.5 & 2.5 & 0.625 \\
\hline $1001-1200$ & & & 3.0 & 0.75 \\
\hline $1201-1400$ & & & 3.5 & 0.875 \\
\hline $1401-1600$ & & & & \\
\hline 1601 or greater & & & & \\
\hline
\end{tabular}

Modified from source: Australian Education Union SA Branch. (2013). School Library Staffing Policy. https://slasa.asn.au/Advocacy/docs/School Library Staffing Policy AEU 2013.pdf

The Role of Teacher librarians (AEU, 2013, p. 2)

A qualified Teacher librarian can be defined as a person who holds recognized teaching qualifications and qualifications in librarianship, defined as eligibility for professional membership for the Australian Library and information Association (ALIA). This dual qualification is valuable because curriculum knowledge and pedagogy are combined with library and information management knowledge and skills. The Teacher librarian plays a critical role in the development of information literate citizens who are lifelong learners. The valuable role of the Teacher librarian focuses on:

- Learners and learning - assisting individuals and class groups to seek, critically evaluate, synthesize and present information; developing strategies to foster a love of reading and literature for leisure.

- Teachers and teaching - collaboratively planning and teaching units of work and providing Professional Development activities that encourage the integration of Information Communication Technologies and the development of information literacy skills.

- Resourcing the curriculum - selecting and managing resources and providing information services to support the teacher and learning programmes of their school community.

- Facilitating access to information - setting up information/knowledge management systems and helping staff and students use a range of resources and information.

- Developing the physical environment - ensuring that the library resource centre is welcoming, userfriendly, multi-functional and a focal point for student learning. 

